UNIVERSIDADE DE SÃO PAULO

FACULDADE DE FILOSOFIA, LETRAS E CIÊNCIAS HUMANAS

DEPARTAMENTO DE GEOGRAFIA

PROGRAMA DE PÓS-GRADUAÇÃO EM GEOGRAFIA HUMANA

\title{
TURISMO E PRODUÇÃO DO ESPAÇO - O CASO DE JERICOACOARA, CE
}

Fábio Silveira Molina 
UNIVERSIDADE DE SÃO PAULO

FACULDADE DE FILOSOFIA, LETRAS E CIÊNCIAS HUMANAS

DEPARTAMENTO DE GEOGRAFIA

PROGRAMA DE PÓS-GRADUAÇÃO EM GEOGRAFIA HUMANA

\title{
TURISMO E PRODUÇÃO DO ESPAÇO - O CASO DE JERICOACOARA, CE
}

Fábio Silveira Molina

\begin{abstract}
Dissertação de mestrado apresentada ao Programa de PósGraduação em Geografia Humana, do Departamento de Geografia da Faculdade de Filosofia, Letras e Ciências Humanas da Universidade de São Paulo, para a obtenção do título de Mestre em Geografia Humana.
\end{abstract}

Orientadora: Profạ. Drạ. Rita de Cássia Ariza da Cruz 
Este trabalho é dedicado aos meus queridos amigos e familiares, especialmente aos meus pais, André e Terezinha Molina, e também à Comunidade da Vila de Jericoacoara, pela bravura na resistência às ações hegemônicas impostas ao seu cotidiano. 


\section{AGRADECIMENTOS}

À minha orientadora, Professora Doutora Rita de Cássia Ariza da Cruz, pela gentileza presente em suas ações, dedicação, respeito às posições por mim apresentadas no decorrer do meu amadurecimento acadêmico e, principalmente, pela confiança em mim depositada, nos momentos em que somos invadidos por tantas incertezas. Fruto das qualidades acima mencionadas, agradeço imensamente pela brilhante orientação a este trabalho, sem a qual o mesmo não teria tido as condições essenciais para sua elaboração.

Aos docentes do Programa de Pós-Graduação em Geografia Humana da FFLCH/USP, pelos ensinamentos transmitidos, competência acadêmica e, também, pela cordialidade e empenho nas discussões extra-classe, que tanto contribuíram para as minhas reflexões.

Agradeço imensamente às professoras que fizeram parte da banca de qualificação desta dissertação, María Laura Silveira e Odette Carvalho de Lima Seabra, pelas primorosas observações apontadas acerca deste trabalho, indicando valiosos caminhos com rigorosa competência acadêmica nas questões de teoria e método em geografia.

Aos colegas do Mestrado em Geografia Humana, especialmente ao André Sabino e Carolina Todesco, que desde o início deste trabalho compartilhávamos nossas posições teórico-metodológicas (por estudarmos o mesmo tema e termos a mesma orientadora) e também nossas angústias enquanto aprendizes, que eram compensadas pelos momentos agradáveis nos intervalos das aulas, reuniões, corredores e, assim, tendo o nosso laço de amizade cada vez mais fortalecido pelo tempo de convívio.

Aos funcionários do Departamento de Geografia da FFLCH/USP, pela prestimosidade com que sempre me atenderam.

Ao Professor Antonio Jeovah de Andrade Meireles, do Departamento de Geografia da Universidade Federal do Ceará, pelas conversas e fornecimento de material fotográfico e cartográfico. 
Ao Núcleo de Estudos Territoriais e do Turismo - NETTUR, do Departamento de Geografia da Universiade Estadual do Ceará, especialmente representados pela Professora Luzia Neide Coriolano e Eluziane Mendes.

À Conceição Malveira Diógenes de Holanda (da Gerência de Desenvolvimento Institucional - PRODETUR/SETUR), Tatiana Sá (arquiteta da Secretaria de Desenvolvimento Local e Regional - SDLR), Tiago Matos (Secretaria do Meio Ambiente do Estado do Ceará - SEMACE), Helena Mota (do Instituto de Pesquisa e Estratégia Econômica do Ceará - IPECE), Janice Monteiro e Jefferson Sousa da Silva (Instituto Terramar).

Ao professor José Osmar Fonteles (Universidade Vale do Acaraú - UVA) e atual chefe do Parque Nacional de Jericoacoara, pelas valiosas informações prestadas e pela generosidade em providenciar minha hospedagem na sede local do IBAMA, durante meu trabalho de campo em Jericoacoara, e à Sra. Josedna da Silva Dias, da Secretaria do Trabalho e Ação Social da Prefeitura Municipal de Jijoca de Jericoacoara.

Ao povoado da Vila de Jericoacoara e aos membros do Conselho Comunitário de Jericoacoara, especialmente à Presidenta, Sra. Maria Filizolina de Souza, à Paula Fraser da Veiga Pacheco e Fábio Nobre, pela disponibilidade que tiveram em responder às minhas inquietações enquanto pesquisador no local, e pelo fornecimento de valiosos registro documentais.

Finalmente, agradeço a todos que, direta ou indiretamente, colaboraram para a realização deste trabalho. 


\section{SUMÁRIO}

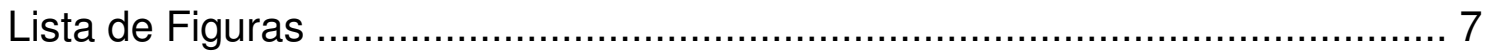

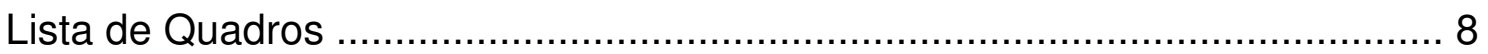

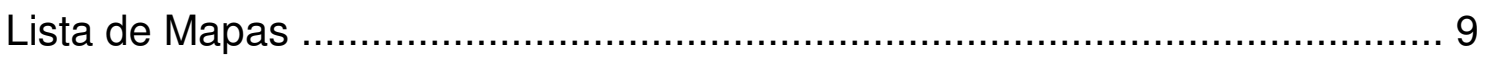

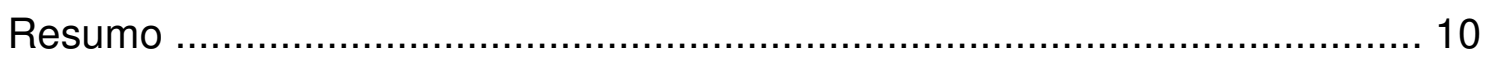

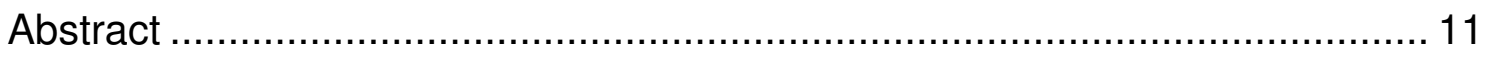

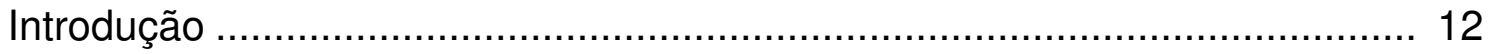

1. Turismo - uma prática social criadora de uma (des)ordem espacial ......... 23

2. O contexto socioespacial do turismo em Jericoacoara ............................. 40

3. Os agentes da produção do espaço local ............................................. 58

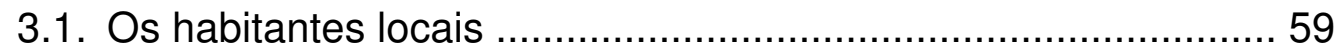

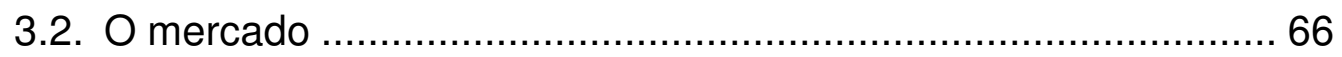

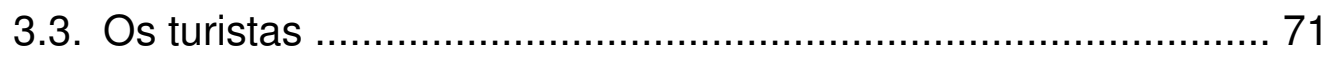

3.4. Os planejadores e promotores territoriais e as políticas de

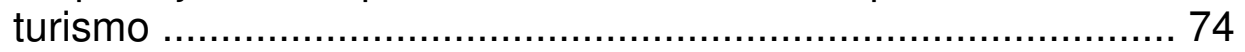

4. Jericoacoara - das contradições gerais à produção

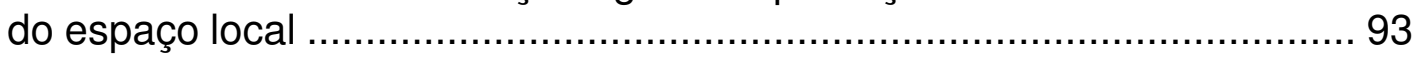

5. Á guisa de conclusão - o turismo e seu lugar na produção do espaço ... 112

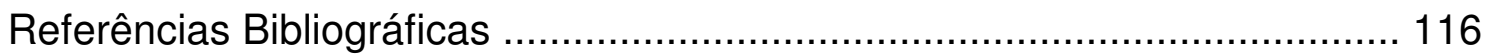

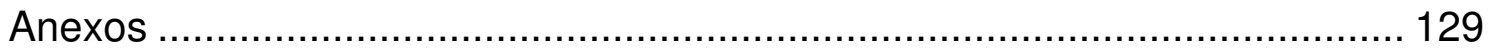

Decreto $\mathrm{n}^{\circ}$ 90.379, de 29 de outubro de 1984 ............................... 130

Decreto $\mathrm{n}$ o 4 de fevereiro de 2002 ................................................... 135

Instrução Normativa oo 4 - de 15 de maio de 1992 ......................... 138

Instrução Normativa oํ 4 - de janeiro de 2001 ............................... 144 


\section{LISTA DE FIGURAS}

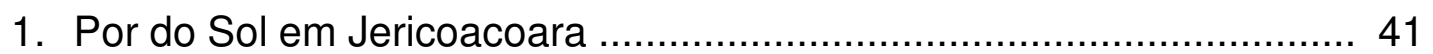

2. Praia de Jericoacoara e, ao fundo, a Duna do Por do Sol................... 42

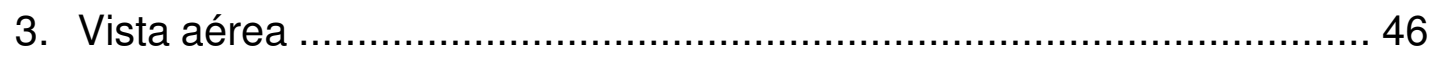

4. Perspectiva espacial da APA de Jericoacoara ..................................... 50

5. Vila de Jericoacoara e, ao fundo, o serrote …………....................... 53

6. Vista parcial da área urbana da vila de Jericoacoara ............................ 54

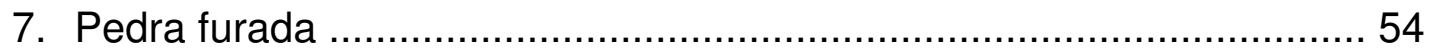

8. Localização da vila, APA e do PARNA de Jericoacoara .......................56

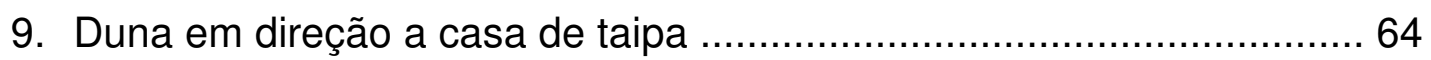

10. $O$ avanço das dunas alcança os limites da vila de Jericoacoara........... 64

11. Plantio de mudas em áreas dunares ................................................... 65

12. Bar "Sky", um dos mais freqüentados na vila ................................... 67

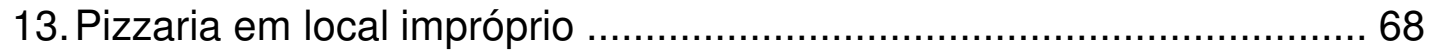

14. Prática do "windsurf" em Jericoacoara ……………............................. 69

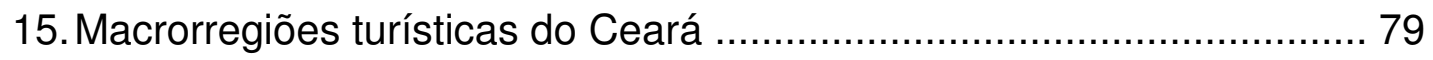

16. Área de abrangência do PRODETUR I e II ............................................ 82

17. Obra localizada no centro da Rua Principal .................................... 100

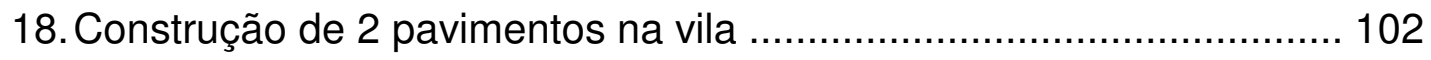

19. Aspecto bucólico de uma rua na vila ............................................... 107

20. Mercado Público e Centro de Artesanato .......................................... 107

21. Piquetes de demarcação da vila ................................................... 108

22. Calçamento (obra embargada) .................................................... 108 


\section{LISTA DE QUADROS}

1. Praias preferidas pelos turistas, excluindo-se o litoral de Fortaleza ..... 41

2. População do Município de Jijoca de Jericoacoara (1991-2005) ........ 48

3. População da Vila de Jericoacoara (1980-2006) ................................ 48

4. Produto Interno Bruto do Município de Jijoca de Jericoacoara,

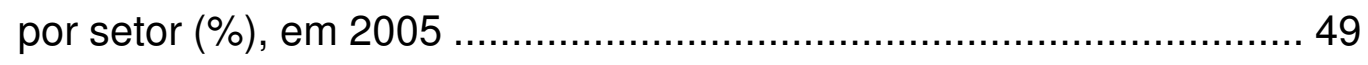

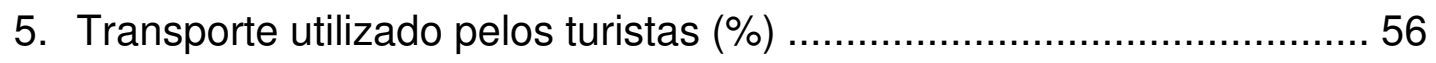

6. Oferta hoteleira de Jericoacoara (2005) .......................................... 70

7. Procedência dos turistas (2005) …………………........................ 73

8. Procedência dos turistas nacionais (2005) ...................................... 73

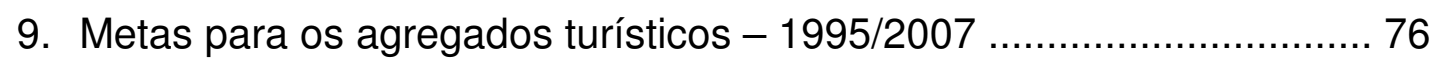

10. Regiões turísticas definidas pelo PRODETURIS (1990)

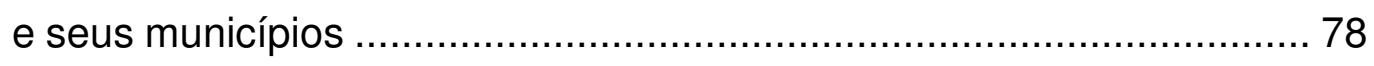

11. Ceará - Macrorregiões turísticas (configuração de 2005) ..................... 78

12. Distribuição dos investimentos e participações na fase I do PRODETUR - CE

13. Análise SWOT das áreas de interesse turístico: Jericoacoara e Camocim (2003) ...................................................... 84

14. Organização dos grupos de discussões no processo de

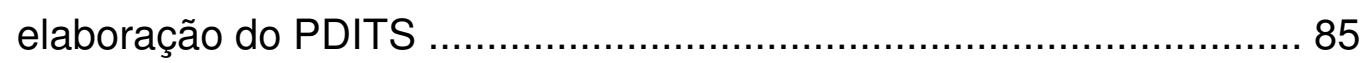

15. Observações acerca da drenagem e urbanização da orla da praia de Jericoacoara 86

16. Financiamento do PRODETUR II para o Nordeste (em milhões de dólares - US\$)

17. Projetos e recursos indicados pelo PDITS para o PRODETUR / CE II 92 


\section{LISTA DE MAPAS}

1. Mapa Municipal de Jijoca de Jericoacoara ........................................ 45

2. Localização regional da APA de Jericoacoara .................................... 51

3. Localização do Parque Nacional de Jericoacoara ............................... 52 


\title{
TURISMO E PRODUÇÃO DO ESPAÇO - O CASO DE JERICOACOARA, CE
}

\author{
Autor: FABIO SILVEIRA MOLINA \\ Orientador: Prof ${ }^{a}$. Dr ${ }^{a}$. RITA DE CÁSSIA ARIZA DA CRUZ
}

\section{RESUMO}

Este trabalho diz respeito à redefinição do espaço local da praia de Jericoacoara, localizada no Estado do Ceará, em função de seu uso turístico, considerando a indiscutível capacidade que tem o turismo de gerar incidências significativas sobre os territórios dos quais se apropria. Assim, buscou-se apreender o processo de apropriação, consumo e transformação (no aspecto físico e humano) deste espaço pelo/para o turismo, basicamente no período compreendido desde sua transformação em APA (Área de Proteção Ambiental), em 1984, até os dias atuais.

Uma premissa teórico-metodológica fundamental sobre a qual se assenta esta pesquisa é a de identificar e analisar os papéis dos agentes de produção de espaços para o turismo, sendo estes os próprios turistas (a presença dos mesmos define o lugar turístico, e toda a produção é direcionada às suas exigências), o mercado (representado pelo ramo empresarial da atividade turística), os planejadores e promotores territoriais (ou seja, o papel do Estado, através das Políticas Públicas de Turismo, Políticas Urbanas e Ambientais), além da comunidade receptora que, no caso de Jericoacoara, teve um papel significante na reivindicação do espaço para a reprodução da própria vida, ao contrário da sua produção somente enquanto valor de troca. 


\title{
TOURISM AND PRODUCTION OF SPACE - THE CASE OF JERICOACOARA, CE
}

\author{
Author: FABIO SILVEIRA MOLINA \\ Advisor: Professor RITA DE CÁSSIA ARIZA DA CRUZ
}

\section{ABSTRACT}

This work refers to the redefinition of the local space of Jericoacoara beach, located in the State of the Ceará, Brazil, related to its tourist use, considering the unquestionable capacity that has the tourism to generate significant incidences on the territories of which it appropriates. Thus, efforts were made to apprehend the process of appropriation, consumption and transformation (in the physical and human aspect) of this space by/to the tourism, basically in the period since its transformation in Area of Environment Protection, in 1984, until the current days.

A theoretician-methodological basis premise on which it seats this research is to identify and to analyze the role of the agents of production of spaces for the tourism: the proper tourists (the presence of the same ones defines the tourist place, and all the production is directed to its requirements), the market (represented by the enterprise branch of the tourist activity), the territorial planners and promoters (that is, the role of the State, through the Public Politics of Tourism, Urban and Environment Politics), and also the local community that, in the case of Jericoacoara, had a significant role in the claim of the space for the reproduction of the proper life, in contrast of its production only while value of exchange. 


\section{INTRODUÇÃO}

A partir de uma visão crítica do espaço e, nele, o turismo, compreendido como um fenômeno criador de uma (des)ordem espacial, o tema tratado nesta dissertação diz respeito à espacialização dos processos ligados à esta prática social, que resultam na apropriação, produção e consumo do espaço, tendo-se em mente que o turismo, ao apropriar-se de um espaço, tende a produzir o seu próprio espaço. As particularidades deste processo serão consideradas buscando-se sua apreensão através da noção de totalidade, tendo-se em mente a indiscutível capacidade que tem o turismo de (re)configurar os territórios dos quais se apropria e de articular ações que ocorrem tanto na dimensão política como na econômica, social e ambiental, nos seus diversos níveis hierárquicos e escalares.

Desta forma, buscou-se neste trabalho a produção de uma fundamentação teórico-metodológica, confrontada à obtenção empírica de dados, através do estabelecimento tácito de um esquema de análise para se apreender o fenômeno num movimento que parte do singular para o universal, e que ainda permitisse o movimento inverso, tendo o espaço como centro epistemológico e fio condutor analítico.

Partindo da premissa de que as reflexões geográficas podem fundar-se na preocupação sobre os conteúdos e usos diferenciados dos territórios, afirmamos que toda pesquisa deve buscar não somente a descrição mas sim 0 sentido dos aconteceres no mundo e nos lugares, apoiada assim na elaboração de um esquema de análise que nos permita apreender os processos que desencadeiam na produção espacial, ou ainda, que nos auxilie no entendimento do espaço geográfico. Nas palavras de Silveira (2000, p. 21), "buscando constituir um patamar na construção das necessárias mediações entre a realidade e as reflexões metodológicas, é possível esboçar um esquema para avançar na compreensão da contínua reorganização do espaço". 
Todo esquema de análise parte de uma teoria, que pretende expressar um conjunto de existências. Ela tem de ser crítica, de maneira que nos permita apreender o fato de que as possibilidades são mais amplas que as existências, e nunca desconsiderá-las historicamente (quando uma determinada teoria foi criada), pois a cada momento histórico há um conjunto de possibilidades e existências concretas. A teorização se dá quando uma categoria é preenchida/atualizada de acordo com o presente histórico ${ }^{1}$.

Assim, a teoria, compreendida como "um conjunto de enunciados, atualmente formulados e potencialmente formuláveis" (Granger, 1994, p. 48), busca evidenciar as possibilidades de um momento histórico e, de um modo geral, ela é a própria interpretação do mundo desde uma perspectiva e desde uma província do saber. Na afirmação de Silveira (2000, p. 24), "como a realidade é dinâmica, os conceitos devem dar conta do movimento. Daí a força do esquema histórico, pois um esquema lógico pode se tornar vazio. Mas, se o esquema não é lógico, não tem operacionalidade nem coerência e, por conseguinte, não permite a explicação do que se passa no mundo". Desta forma, com uma determinada teoria e seu sistema de conceitos tenta-se interpretar o mundo e os lugares, buscando-se inclusive a coerência na explicação entre o que existe e o que seria possível (capacidade de previsão), com base, portanto, num esquema de análise.

A produção de um esquema de análise daquilo que se pretende pesquisar parte de uma teoria maior (sistemas de categorias e conceitos, datados, com pretensão universal e operacional) para uma teoria menor (o concreto pensado, ou a realidade a qual se pretende desvendar). O esquema deve ser ao mesmo tempo coerente, pertinente e operacional: coerente, com o período histórico em que se dá a pesquisa; pertinente, quando relacionado adequadamente com o objeto da pesquisa e objeto da disciplina; e operacional, na medida em que se dá a escolha correta dos instrumentos de análise que nos possibilitam conhecer/desvendar o real e assim à busca de dados (Silveira,

\footnotetext{
${ }^{1}$ É comum, entre alguns pesquisadores, o apelo a metáforas, ao invés de atualizarem uma categoria e torná-la conceito. Neste sentido, "a metáfora toma claramente o lugar da teoria e impede de encontrar um método explicativo, enquanto favorece a proliferação de discursos" (Santos, M. e Silveira, M. L., 1997, p. 23); trabalhar com meias verdades não abre perspectivas analíticas.
} 
2000). Esta operacionalidade diz respeito também à possibilidade de partir-se de um conceito geral (por exemplo, espaço) até chegar-se a um mais singular (por exemplo, lugar), e que neste caminho possa ocorrer ainda o movimento inverso.

A produção do conhecimento passa por uma ontologia (visão do mundo) e uma epistemologia, que são os procedimentos pelos quais se dão as tentativas de se explicar o mundo, ou ainda, "o estudo metódico e reflexivo do saber, de sua organização, de sua formação, de seu desenvolvimento, de seu funcionamento e de seus produtos intelectuais" (Japiassu, 1979, p. 16). Este autor propõe uma epistemologia particular, relacionada a um campo particular do saber, diferenciando-se de uma epistemologia global ou geral, que se trata do saber globalmente considerado. A passagem de uma epistemologia geral para uma epistemologia particular é necessária na nossa análise; desta forma, é a partir da epistemologia particular da geografia que tentaremos chegar a uma epistemologia que nos permita compreender a relação turismo e espaço, e este processo deve ser acompanhado da idéia de totalidade, levando-se em consideração que o mundo é uma totalidade em permanente movimento.

Para que uma explicação do mundo seja alcançada, tem-se que buscar as categorias e conceitos mais apropriados ao estudo de um determinado objeto de pesquisa. Uma crítica dos conceitos, para que os mesmos sejam selecionados, é necessária à construção da análise e, neste sentido, verificar se determinadas categorias e conceitos serão úteis à análise do mundo da forma em que o mesmo se encontra nos remete à uma análise da nossa epistemologia.

No intuito de se compreender singularidades do processo de produção espacial pelo uso turístico do território, o tema em desenvolvimento nesta pesquisa toma a praia de Jericoacoara como recorte espacial e estudo de caso. Entretanto, este local não é o objetivo final deste trabalho, ou seja, os esforços aqui empreendidos são para desvendar, primordialmente, aspectos da produção do espaço relacionados ao turismo; desta forma, a preocupação fundamental não é a compreensão do local por ele mesmo, mas utilizar deste 
exemplo para compreender a relação entre turismo e processo de produção espacial, no sentido amplo. Assim sendo, temos em mente que

\begin{abstract}
Um fenômeno específico reproduz, em diferentes escalas, as mesmas determinações da totalidade, sem com isso eliminarse as particularidades históricas. Entretanto, na produção de uma pequena parcela de espaço encontramos as mesmas determinações, a mesma articulação. É possível detectar as leis gerais do processo de produção espacial a partir da análise de uma determinada parcela, desde que esta leve em conta a relação com a totalidade. Esta idéia apóia-se numa visão determinada de realidade, na qual os fenômenos só tem sentido quando analisados em função do todo ao qual pertencem (Carlos, 1994, p. 39).
\end{abstract}

Reconhece-se, porém, que as existências e as possibilidades presentes em Jericoacoara podem ser únicas e características deste local e não se aplicar a outros lugares, mas este fato não exclui a pretensão de se compreender o fenômeno em sua forma abrangente e geral, uma vez que se pode ainda admitir, por exemplo, que o uso turístico em Jericoacoara, ou de outra área da mesma forma rica em termos de ambientes naturais e litorânea, pode ocorrer em decorrência da "saturação" dos grandes centros urbanos, que acaba por produzir a necessidade, em suas "multidões solitárias"2, de se ausentar temporariamente da esquizofrenia dos grandes centros, no tempo do não-trabalho. Isso pode explicar, em parte, a natureza do uso efêmero, por parte dos turistas, de territórios distantes do seu local de moradia; estes são consumidores em potencial de uma mercadoria, nestes casos, produzida para o seu desfrute: o espaço. Esta necessidade de consumo por parte dos turistas é conseqüência da ação dos "produtores", que

...têm um permanente interesse em cultivar "o excesso e a intemperança" nos outros, em alimentar "apetites imaginários" a ponto de as idéias sobre o que constitui a necessidade social serem substituídas pela "fantasia, pelo capricho e pelo impulso. O produtor capitalista tem cada vez mais "o papel de alcoviteiro" entre os consumidores e seu sentido de necessidade, excitando neles "apetites mórbidos, à espreita de cada uma de suas fraquezas... (Harvey, 2004, p. 99).

\footnotetext{
${ }^{2}$ Termo utilizado por Guy Debord (2005, p. 23) ao fazer referência à condição de isolamento frente à produção e ao consumo de alguns bens como o automóvel e a televisão.
} 
Jericoacoara não pode ser compreendida, portanto, por si mesma, uma vez que a apreensão da realidade remete diretamente ao movimento da totalidade. A realidade "corresponde à unidade do mundo refazendo-se, a cada dia, nos lugares" (Silveira, 2002, p.11).

Partimos ainda da consideração de que a produção espacial se dá sob a atuação do Capital, do Estado e da Sociedade, em sentido amplo; estes agentes, além de atuarem no processo de produção espacial, são também os responsáveis pela sua fragmentação, uma vez que se presencia o uso diferenciado das parcelas do espaço, fruto do interesse divergente dos sujeitos sociais envolvidos.

No caso específico do turismo, o Capital é representado pelo Mercado, ou seja, pelos agenciadores e empresários da atividade (o ramo empresarial, representado pelas agências de viagens, a rede hoteleira, a construção civil, empresas de transporte, empresas na área de gastronomia, comércio e prestação de serviços ao turista, entre outros). O Estado (setor público) revelase basicamente através de ações de Planejamento e Políticas Públicas ligadas ao turismo, e a Sociedade é representada, basicamente, pelos próprios turistas (que não são mais que pessoas temporariamente fora de seus lugares de residência) e pelos habitantes dos "lugares turísticos".

Uma das premissas orientadoras desta investigação é aquela que entende o turismo como uma prática social; a segunda premissa diz respeito ao entendimento de que é o homem o elemento central na discussão acerca da produção do espaço, uma vez que ele produz espaço para a (re)produção da própria vida em sociedade. Conforme aponta Carlos (1996), o espaço é produto, condição e meio de toda a atividade humana. É um produto histórico e social das relações que se estabelecem entre a sociedade e o meio circundante, relação esta mediada pelo trabalho.

Sendo um conjunto indissociável entre um sistema de objetos e um sistema de ações (Santos, 2002a), o espaço, sinônimo de território usado, é produzido a partir da reprodução humana, fato este que levou o autor a afirmar 
que viver, para o homem, é produzir espaço, e "por território entende-se geralmente a extensão apropriada e usada" (Santos e Silveira, 2004b, p.19).

O espaço é produzido em função da reprodução ampliada do capital que, conforme Harvey (2004, p, 307), "é um processo, e não uma coisa":

É um processo de reprodução da vida social por meio da produção de mercadorias em que todas as pessoas do mundo capitalista avançado estão profundamente implicadas. Suas regras internalizadas de operação são concebidas de maneira a garantir que ele seja um modo dinâmico e revolucionário de organização social que transforma incansável e incessantemente a sociedade em que está inserido. O processo mascara e fetichiza, alcança crescimento mediante a destruição criativa, cria novos desejos e necessidades, explora a capacidade do trabalho e do desejo humanos, transforma espaços e acelera o ritmo da vida.

Capaz de transformar consideravelmente o espaço do qual se apropria, o turismo, mesmo nas suas formas ditas alternativas ${ }^{3}$, é um fenômeno que demanda infra-estruturas, como vias de circulação, meios de hospedagem e alimentação. Ou seja, ele é muitas vezes o elemento re-orientador de uma realidade local, transformando espaços à sua conveniência, uma vez que a atividade proporciona a circulação, no território, tanto de pessoas como de bens e serviços. O turismo é, muitas vezes, a causa principal do consumo e valorização do espaço, não raras vezes transformando objetos naturais em objetos de consumo.

Anteriormente à especialização do lugar para o turismo, Jericoacoara era uma comunidade pesqueira situada no litoral oeste do estado do Ceará, sem a presença de infra-estruturas urbanas, e de difícil acesso, devido à grande quantidade de dunas circundantes. À respeito da produção espacial do espaço na zona costeira cearense, Lima (2002, p.60) elenca quatro principais situações históricas:

\footnotetext{
${ }^{3} \mathrm{Ou}$ seja, as formas que se opõem ao turismo massificado, como exemplo, o turismo em áreas naturais ou áreas (urbanas ou não) pouco visitadas, por apresentarem algum "atrativo" que talvez não interesse à maioria das pessoas, ou por apresentarem condições ínfimas de infra-estrutura (acessibilidade, acomodação, alimentação, etc).
} 
...a primeira, observada até fins da década de 60 do século $X X$, relativa ao uso e à ocupação da zona costeira por comunidades tradicionais, cidade portuária (Fortaleza) e cidades costeiras (Camocim, Aracati e Paracuru). A segunda, a partir do início da década de 1970, inicia-se com o processo de construção dos "paraísos cearenses" (com a "descoberta" da praia de Canoa Quebrada) e surgem os "viajantes" em diferentes localidades praianas - inicialmente, deu-se a chegada de pessoas às casas dos pescadores, pedindo pouso; o veraneio chegou aos municípios costeiros vizinhos à Fortaleza (Icaraí e Cumbuco, município de Caucaia; Prainha, município de Aquiraz). A terceira, até meados da década de 1980, surgiu com os grileiros e especuladores imobiliários nas praias; casas de nativos (na sua maioria de taipa) foram e ainda são compradas e, em seguida, transformadas em segundas-residências - o veranismo alcançou municípios cearenses distantes da capital; pescadores e mulheres de pescadores deixaram seus afazeres costumeiros e passaram a ser "caseiros"; evidenciaram-se vários casos de disputa pela posse da terra. A quarta, final da década de 1980/início da década de 1990, remete ao processo de urbanização (turística) e "incorporação produtiva" do litoral cearense à economia nacional e internacional.

Com o crescimento acelerado do turismo, Jericoacoara passa por significativas transformações no aspecto físico e humano, cujo marco histórico é definido pela transformação, do lugar, em Área de Proteção Ambiental, em 1984. Este fato pode ser considerado um evento, impulsionador de transformações espaciais no plano da forma-conteúdo.

Os eventos "mudam as coisas, transformam os objetos, dando-lhes, ali mesmo onde estão, novas características ... " (Santos, 2002a, p. 146). Assim, um evento, uma unidade de tempo, é também uma sucessão de mudanças numa existência (um acontecer), ou ainda, o resultado de uma ação num objeto.

Mas os eventos, conforme Santos (op. cit.), "também são idéias e não apenas fatos. Uma inovação é um caso especial de evento, caracterizada pelo aporte a um dado ponto, no tempo e no espaço, de um dado que nele renova um modo de fazer, de organizar ou de entender a realidade" (p. 148).

Cabe ressaltar que nas localidades muitas vezes há resistências aos eventos, pois a ação se dá nos lugares, e estes já têm seu conjunto de 
existências cristalizadas. Toda ação cria um efeito sobre determinado objeto, porém este pode também criar um retro-efeito sobre a ação (tornar esta possível, ou não). São, no dizer de Santos (2002a, p. 308), as contraracionalidades, que surgem a partir da racionalidade hegemônica, "desejosa de tudo conquistar". Desta maneira, a ação é mais eficaz quando os objetos são mais adequados a ela.

O evento é também uma fração da totalidade em movimento que se deposita numa fração da totalidade cristalizada; ele tem duração e extensão (uma área territorial de ocorrência politicamente determinada). Seja qual for a escala/extensão do evento, é importante ressaltar que o mesmo possui um agente ou um conjunto de agentes responsáveis (tanto para o mesmo sucederse ou acabar-se).

Visto pela idéia de totalidade, há de se considerar que os eventos são superpostos e se sucedem (criam continuidade), e atuam como uma unidade de tempo. Neste sentido, o turismo, ao apropriar-se dos territórios, defronta-se com eventos passados cristalizados no espaço e atua como uma unidade de tempo, que nos permite a periodização (uma unidade do tempo capaz de produzir espaço e se desenvolver a partir deste espaço). Assim, o espaço é produto e produtor de um período, que é um conjunto de possibilidades reais/concretas do mundo. Porém, nem todos os agentes são capazes de utilizar estas possibilidades, na medida em que há normas que autorizam ou não certos comportamentos. São as temporalidades (tempos no tempo) que nos permitem apreender o que cada agente pode fazer, como se usa 0 território, quem é hegemônico e quem é hegemonizado, uma vez que no tempo do lugar ocorre e pode ocorrer, verticalmente, a imposição do tempo de outro lugar, alterando-o.

O turismo impõe novas relações sociais nos lugares e se materializa no território com a introdução de novos sistemas de objetos, imbricados a novos e antigos sistemas de ações. Conforme Luchiari (1998, p.18), "essa readequação significa, do ponto de vista de uma análise espacial, a criação de um sistema de objetos que dê familiaridade ao novo sistema de ações trazido pela demanda social do turismo". 
Destacando-se como um dos principais destinos turísticos do estado do Ceará, Jericoacoara tem sido amplamente divulgada entre os roteiros turísticos nacionais, tornando-se, assim, um espaço cada vez mais visitado por turistas de todas as regiões do país e muitos também do exterior. A vila tem sido, cada vez mais, dotada de um conteúdo técnico e informacional. Este processo de tornar os lugares diferenciados (e especializados) de forma atrativa ao capital resulta na "produção da fragmentação, da insegurança e do desenvolvimento desigual efêmero no interior de uma economia de fluxos de capital de um espaço global altamente unificado" (Harvey, 2004, p. 267).

Jericoacoara especializa-se em função do turismo, e este certamente proporciona rentabilidade econômica ao local, ao mesmo tempo em que começa a demonstrar alguns sinais de desgaste ambiental e consideráveis problemas sociais, reflexo local de determinações globais. Este fato nos levou à escolha deste local para estudo, entendendo-o como um exemplo elucidativo da relação entre turismo e processo de produção e consumo do espaço.

Uma vez que o turismo surge num modo de produção que se baseia na especulação e na conservação da lucratividade, ele muitas vezes é causa e conseqüência da fetichização dos lugares ${ }^{4}$. Esta observação torna-se fundamental às nossas análises, pois o fetichismo é marcado por uma "preocupação direta com aparências superficiais que ocultam significados subjacentes"5; assim, esforços foram empreendidos no sentido de se desvendar as relações sociais e compreender a realidade, "mascarada" nos discursos, nas ações, nos objetos, na paisagem.

No intuito de construir o suporte teórico-metodológico necessário ao alcance do objetivo geral antes exposto, esta pesquisa apoiou-se, basicamente, sobre dois eixos de investigação. O primeiro tratou da análise do conjunto de atividades que compõem o fenômeno turístico, seus fundamentos estruturais, seu papel no processo de produção do espaço e a articulação entre essas diferentes dimensões. Neste caso, foram consideradas as diferentes escalas espaciais do fenômeno o que, conseqüentemente, rebateu sobre 0

\footnotetext{
${ }^{4}$ O termo "fetichização dos lugares", associado ao turismo, foi utilizado por Maria Laura Silveira (1997).

${ }^{5}$ Harvey, 2004, p. 80-81.
} 
segundo eixo de investigação, que tratou especificamente da análise do caso. Esta parte da pesquisa, toda ela de gabinete, envolveu o levantamento bibliográfico e a consulta a fontes secundárias como livros, periódicos acadêmicos e dissertações e teses sobre esta temática.

O segundo eixo ocorreu após a fase inicial de pesquisa de gabinete, onde realizou-se a pesquisa exploratória/investigativa de campo em Jericoacoara e também na capital cearense, Fortaleza, que se apresenta como uma importante fonte de pesquisa documental/bibliográfica (em órgãos diversos e universidades). Isso porque na capital as maiores decisões são estabelecidas para o desenvolvimento do turismo no estado, além de ser a porta de entrada dos turistas para as demais localidades turísticas do Ceará. Esta fase da pesquisa foi central na busca de fontes primárias, e envolveu pesquisa documental, como Plano Diretor, legislações e diretrizes (urbanas, turísticas, ambientais) de uso e ordenamento do espaço cearense e, também, em Jericoacoara.

Assim, visitas foram realizadas em diversos órgãos públicos estaduais (Secretaria de Turismo do Estado do Ceará - SETUR/CE, Secretaria de Desenvolvimento Local e Regional - SDLR, Superintendência Estadual do Meio Ambiente do Estado do Ceará - SEMACE e Instituto de Pesquisa e Estratégia Econômica do Ceará - IPECE), universidades (Universidade Estadual do Ceará - UECE, Universidade Federal do Ceará - UFC e Universidade de Fortaleza - UNIFOR) e uma organização não-governamental (Instituto Terramar).

Algumas técnicas e instrumentos de observação para análise do caso foram utilizados, conforme Abramo (1979) e Cicourel (1980). O primeiro tratase da observação direta não-participante, na qual o pesquisador se coloca em situação de espaço e tempo que lhe permita assistir às manifestações do fenômeno a ser estudado utilizando-se, como forma de registro das observações, a caderneta de campo e a câmera fotográfica.

Entrevistas junto a sujeitos sociais envolvidos diretamente com o processo de produção do espaço do turismo em Jericoacoara foram realizadas, 
com o intuito de investigar a dinâmica das relações sociais subjacentes ao processo analisado e suas implicações no espaço, e identificar eventuais confrontos entre territorialidades distintas e mudanças decorrentes da lógica de organização sócio-espacial imposta pelo turismo. A identificação de marcos históricos e a evolução histórica das infra-estruturas também foram analisadas, no intuito de auferir as transformações ocorridas no local com o passar do tempo, decorrentes da atividade turística. Assim, foram realizadas pesquisas na Sede Local do IBAMA e na Prefeitura do Município de Jijoca de Jericoacoara, e diálogos foram travados com membros do Conselho Comunitário de Jericoacoara, com proprietários (e funcionários) de algumas pousadas, restaurantes, bares e outros estabelecimentos comerciais, e ainda com moradores locais e turistas, advindos de diversas localidades do país e do exterior.

Após a apresentação do tema, do problema, do local de estudo e algumas questões de método, presentes nesta introdução, este trabalho estrutura-se em cinco capítulos. O primeiro deles refere-se à fundamentação teórico-metodológica acerca da relação turismo e espaço, compreendendo o turismo como uma prática social criadora de uma (des)ordem espacial. $O$ segundo diz respeito ao contexto socioespacial e o turismo em Jericoacoara, onde buscou-se discorrer sobre a caracterização do local e o processo de turistificação, o qual vem ocorrendo desde meados da década de 1970.

O terceiro capítulo trata da apresentação e análise do papel dos diversos agentes de produção espacial em Jericoacoara: os habitantes locais, o mercado, os turistas e os planejadores e promotores territoriais (aqui, com ênfase no papel do estado do Ceará no que diz respeito fundamentalmente às políticas públicas de turismo).

No capítulo seguinte (quarto), o foco de análise está no papel dos planejadores e promotores territoriais ao nível local e a luta pelo espaço produzido, fruto de contradições, seguido do capítulo (quinto) referente às considerações finais acerca do turismo e seu papel na produção do espaço. 


\title{
1. TURISMO - UMA PRÁTICA SOCIAL CRIADORA DE UMA (DES)ORDEM ESPACIAL
}

A prática social do turismo é capaz de dinamizar e/ou articular diversas atividades e ramos da economia, e reflete ainda as determinações da sociedade na qual está inserida, que é contraditória, conflituosa, controversa, reflexo também de lógicas do momento histórico presente, como o processo de globalização, ou período técnico-científico-informacional (Santos, 2003). Ocupa, também, um papel de destaque na acumulação/reprodução do capital, uma vez que a circulação de pessoas gera também circulação de capital, principalmente por meio do consumo de bens e serviços. O processo de acumulação do capital como reprodução social, conforme Martins (2001, p.22),

\begin{abstract}
...carrega conflitos em suas próprias entranhas, uma vez que se trata de recalcar e acomodar nas malhas do mercado, esvaziando de sentido histórico, as formas contemporâneas que não estejam em plena consonância com a expansão do capital, ou, o que é pior, trata-se de aniquilá-las, quando de algum modo venham a questioná-la. Nesse encurralamento, o Estado desempenha papel de primeira grandeza.
\end{abstract}

Nas palavras de Smith (1988, p. 140), o capitalismo "foi bem sucedido em realizar seu 'crescimento'. Nós não podemos calcular a que preço isto se deu, mas podemos saber os meios utilizados: pela ocupação do espaço, pela produção do espaço". Neste sentido, "é preciso uma análise da prática e atividade turística estabelecendo sólidas relações entre as tendências observadas no turismo e as tendências e relações gerais da sociedade" (Bertoncello, 1998, p. 73).

Bertoncello aponta, também, para a necessidade da superação de leituras dicotômicas do turismo e seus impactos, pois o turismo é uma atividade muito ampla, complexa, que envolve diversas relações, dimensões, formas, e reduzi-lo a algo ora negativo ora positivo seria algo reducionista e maniqueísta. O mesmo afirma Daniel Hiernaux Nicolas (1996, p. 45), citando Lanfant, ao dizer que uma análise que privilegie somente os impactos do turismo trata-o 
como algo exterior e o turista um intruso, desconsiderando o fato de que 0 turismo não é "uma atividade exterior ao espaço e a sociedade, e sim um fator constitutivo das sociedades atuais". É necessária uma leitura que compreenda basicamente os processos sociais ligados a esta prática, ou seja, os que motivam as viagens, os que dão suporte para que estas possam ocorrer, e os que permitem as condições para que o turismo ocorra nos lugares.

Tecnicamente, o turismo utiliza-se de diversas infra-estruturas como as de transporte (hidroviário, rodoviário, ferroviário, aéreo), a rede hoteleira, agências de viagens, transportadoras, infra-estruturas de alimentação, comércio e serviços. O turismo apóia-se também em infra-estruturas préexistentes nos lugares e que não têm relação direta com a atividade, como as de saneamento básico, energia, comunicações, os serviços bancários, de saúde, de iluminação pública, de segurança, entre outros.

O turismo apresenta números expressivos, principalmente nas estatísticas apresentadas pela OMT (Organização Mundial do Turismo) e outros organismos oficiais (como a Embratur ${ }^{6}$, no Brasil), que a colocam como a "indústria" mais promissora, em constante crescimento, geradora de um grande volume de divisas e assim como uma alternativa para 0 desenvolvimento econômico.

Uma vez que as estatísticas sobre a atividade mostram números expressivos no mundo, o planejamento territorial pode ser um instrumento importante para minimizar os efeitos do crescimento desordenado do turismo, o qual pode acarretar impactos socioambientais como a degradação do meio ambiente, degradação da cultura e dos costumes locais, bem como o uso massivo de infra-estruturas essenciais à vida cotidiana nos lugares, principalmente em épocas de alta temporada, quando normalmente se verifica grande acúmulo de resíduos sólidos e comprometimento do abastecimento de água, por exemplo. Nas palavras de Hall (2004, p. 17),

...embora a afirmação de que ele é a maior área de atividade econômica do mundo seja uma verdade muitas vezes citada, o turismo é importante não só por seu tamanho em termos de

\footnotetext{
${ }^{6}$ Instituto Brasileiro de Turismo.
} 
pessoas que viajam, número de empregados ou quanto dinheiro leva até um certo destino; mas devido ao enorme impacto que exerce na vida das pessoas e nos locais em que elas vivem, e devido à forma pela qual ele é significativamente influenciado pelo mundo que o rodeia.

Em sua obra sobre planejamento do espaço turístico no contexto da América Latina, Boullón (2002, p. 8) enfatiza que um aspecto de extrema importância no planejamento é o de organizar as ações do homem sobre o território, e "planejar bem o espaço é descobrir sem erro como é a realidade (nossa realidade, não outra), e ser capaz de imaginar aquilo que devemos agregar-Ihe, para que, sem que perca seus atributos, adapte-se a nossas necessidades". A atribuição de uma função turística ao território implica na sua adequação a esta nova especialização, e esta é, para Sánchez (1991, p. 224), a premissa maior por meio da qual se dá a produção do espaço pelo/para o turismo.

Ao discutir a dialética sócio-espacial, que consiste na ênfase sobre a qual as relações sociais e espaciais são dialeticamente inseparáveis e interdependentes, Soja (1993, p. 99) afirma que:

\begin{abstract}
A estrutura do espaço organizado não é uma estrutura separada, com suas leis autônomas de construção e transformação, nem tampouco é simplesmente uma expressão a estrutura de classes que emerge das relações sociais (e, por isso, a-espaciais?) de produção. Ela representa, ao contrário, um componente dialeticamente definido das relações de produção gerais, relações estas que são simultaneamente sociais e espaciais.
\end{abstract}

O espaço não deve ser tratado somente enquanto localização, algo estático, e sim enquanto processo, superando-se a velha noção de um mero palco das atividades humanas. Ao considerar que a natureza do espaço é multifacetada, Gottdiener (1993, p. 127) afirma:

O espaço não pode ser reduzido apenas a uma localização ou às relações sociais da posse de propriedade - ele representa uma multiplicidade de preocupações sociomateriais. O espaço é uma localização física, uma peça de bem imóvel, e ao 
mesmo tempo uma liberdade existencial e uma expressão mental. O espaço é ao mesmo tempo o local geográfico da ação e a possibilidade social de engajar-se na ação. Isto é, num plano individual, por exemplo, ele não só representa o local onde ocorrem os eventos (a função de receptáculo), mas também significa a permissão social de engajar-se nesses eventos (a função de ordem social).

Fundamentalmente, o espaço é um produto social e histórico, reflexo da articulação das relações sociais, e produzido socialmente através do trabalho. Nas palavras de Santos (2002a, p. 63),

O espaço é formado por um conjunto indissociável, solidário e também contraditório, de sistemas de objetos e sistemas de ações, não considerados isoladamente, mas como o quadro único no qual a história se dá [...] de um lado, os sistemas de objetos condicionam a forma como se dão as ações e, de outro lado, o sistema de ações leva à criação de objetos novos ou se realiza sobre objetos preexistentes. É assim que o espaço encontra a sua dinâmica e se transforma.

Esta afirmação abre perspectivas de se compreender o espaço não somente como produto, mas também como produtor. A norma é um elemento constitutivo do espaço e do território (ou a extensão apropriada e usada), e é um princípio para a ação, esta sendo criadora do território normatizado. 0 território usado é sinônimo de espaço geográfico e "o uso do território pode ser definido pela implantação de infra-estruturas, para as quais estamos igualmente utilizando a denominação de sistemas de engenharia, mas também pelo dinamismo da economia e da sociedade" (Santos e Silveira, 2004b, p.21).

O território também é uma norma (comporta-se como norma) na medida em que suas existências são um princípio para as ações ${ }^{7}$. No dizer de Smith (1988, p.132), "por suas ações, a sociedade não mais aceita o espaço como um receptáculo, mas sim o produz; nós não vivemos, atuamos ou trabalhamos 'no' espaço, mas sim produzimos o espaço, vivendo, atuando e trabalhando",

\footnotetext{
${ }^{7}$ É importante ressaltar, neste sentido, que há lugares mais aptos ou menos aptos para o exercício das ações, uma vez que existe uma racionalidade hegemônica que cria e impõe suas normas ao mesmo tempo em que há também uma contra-racionalidade (resistência) nos lugares.
} 
além do fato de que "ele próprio constitui uma força produtiva" (Martins, 2001, p. 25).

A partir da noção de espaço, Milton Santos (2002a, pp. 22-23) reconhece suas categorias analíticas internas e externas. Entre as categorias internas encontram-se a paisagem, a configuração territorial, a divisão territorial do trabalho, o espaço produzido ou produtivo, as rugosidades e as formasconteúdo. Entre as categorias externas, destacam-se a técnica, a ação, os objetos, a norma e os eventos, a universalidade e a particularidade, a totalidade e a totalização, a temporalização e a temporalidade, a idealização e a objetivação, os símbolos e a ideologia. As idéias de meio, paisagem, território, lugar, região, divisão do trabalho, além das outras explicitadas acima são elementos constitutivos do espaço ${ }^{8}$.

A produção do espaço se dá cotidianamente, e envolve sujeitos sociais hegemônicos, não-hegemônicos e sujeitos sociais hegemonizados; é fruto, ainda, da necessidade constante de valorização do espaço à curto prazo, tendo-se como produto sua alienação, produzido como a negação da vida social. Dependendo de cada momento histórico, os homens o produzem de modo específico, diferenciado de acordo com o estágio de desenvolvimento das forças produtivas. Conforme Santos (1996, p. 64, 88) "a produção do espaço é resultado da ação dos homens agindo sobre o próprio espaço, através dos objetos, naturais e artificiais [...] não há produção que não seja produção do espaço, não há produção do espaço que se dê sem o trabalho. Viver, para o homem, é produzir espaço". Antes de ser produzido, o espaço é apropriado e, assim:

Cada apropriação do espaço implica uma nova atribuição de coerência e uma nova lógica que adquire conteúdo com um devir social específico, no qual se tecem o individual e o coletivo. Transforma-se o espaço ao se transformar a sociedade, e em cada uma dessas transformações está envolvida uma atribuição de uma temporalidade particular que é a que vive a sociedade particular num dado momento [e], assim, apropriar-se de um espaço é reconstruir sua lógica temporal, é reativar um mecanismo de articulação entre tempo

\footnotetext{
${ }^{8}$ O espaço é híbrido no sentido de sua constituição (dimensões materiais e imateriais) e também no sentido das escalas (local, regional, nacional, global).
} 
e espaço, diferente do anterior (Hiernaux Nicolás, 2002, p. 8586).

O processo de produção da vida é o processo de produção do espaço, e este pressupõe ainda que a realidade está em constante movimento e, assim, em constante processo de transformação. Conforme Soja (1993, p. 115):

...o espaço socialmente produzido (essencialmente, o espaço urbanizado do capitalismo tardio, mesmo no campo) é onde se reproduzem as relações dominantes de produção. Elas são reproduzidas numa espacialidade concretizada e criada, que tem sido progressivamente 'ocupada' por um capitalismo que avança, fragmentada em pedaços, homogeneizada em mercadorias distintas, organizada em posição de controle e ampliada para a escala global. A sobrevivência do capitalismo tem dependido dessa produção e ocupação distintas de um espaço fragmentado, homogeneizado e hierarquicamente estruturado - obtido, sobretudo, através do consumo coletivo burocraticamente controlado (isto é, controlado pelo Estado)...

Num mundo em que impera a lógica da mercadoria, o espaço é reduzido também à mercadoria, sendo cada vez mais produzido para dar condições à reprodução do capital. Sobre esta questão, Gottdiener (1993, p. 133) afirma que:

...o espaço é produzido como nenhuma outra mercadoria. Tem ao mesmo tempo uma realidade material e uma propriedade formal que o capacita a encerrar a realidade material de outras mercadorias e suas relações sociais. Exatamente como outras mercadorias, ele representa ao mesmo tempo um objeto material e um processo que envolve relações sociais.

Desta forma, o espaço é cada vez mais produzido em função do seu valor de troca, e "é um objeto de consumo, um instrumento político e um elemento na luta de classes" (Gottdiener, 1993, p. 127).

Uma vez que o espaço torna-se fonte de novas contradições, Duarte (2001, p. 76) evidencia que "três práticas sociais se opõem: a estatista (a necessidade de um espaço "racional", até mesmo como mera representação 
para uma sociedade desigual, irracional) e a dos grandes interesses privados (capitalistas, rentistas, sem esquecer suas contradições internas) - e estas duas contra as ações sociais (coletivas) que lutam para usar, para 'diferenciar'”.

No que diz respeito ao Estado, este atua na execução de planejamento e de políticas públicas, responsável pelo ordenamento, regulação e gestão do território, e também "assume as funções de mantenedor da ordem estabelecida; vale dizer, garantirá a reprodução das relações de produção dominantes, mesmo que tenha que ceder, conjunturalmente, a certas pressões das classes subordinadas" (Barrios, 1986, p. 7). O Estado é cada vez mais comprometido com a reprodução do capital, criando as condições para que este se realize. Neste sentido, há uma certa dependência entre o capital e o Estado, e o predomínio econômico cada vez mais assegurado pelo político (Martins, 2001, p. 15).

A produção do espaço pode ser compreendida, portanto, como uma conseqüência das relações entre processos econômicos, políticos, sociais, que apresentam uma manifestação espacial, e também como a complexa articulação entre um sistema de objetos e um sistema de ações que se geografizam no espaço, que está em constante movimento de transformação e ligado à idéia de processo, social e histórico.

A relação turismo e espaço se traduz fundamentalmente na indiscutível capacidade que tem o turismo de (re)organizar os territórios à sua conveniência, no intuito de criar as condições para que o mesmo possa ocorrer.

O turismo pode desencadear um consumo consumptivo (e não criativo) do espaço enquanto objeto. Sobre o espaço-objeto, coloca Martins:

É preciso ter em mente que a reprodução ampliada do capital implica a reprodução ampliada das contradições que seu movimento incorpora e engendra. Trata-se, em verdade, do próprio movimento do mundo das mercadorias, no e pelo qual o espaço se torna objeto, não apenas de compra e venda, pois isso acompanha a imposição de atividades diversas e parcelares pela sociedade burguesa, mas sobretudo sua produção se torna objeto das estratégias que visam a 
impulsionar a acumulação de capital, e, portanto, tende a dominar a prática social (2001, p. 29).

Produzir o espaço para a venda e consumo implica, entre outras coisas, na vitória do valor de troca sobre o valor de uso, e o espaço mercadoria limita seu uso às formas de apropriação privada. Gottdiener (1993, p. 129) suscita que há um espaço de consumo e há também um consumo do espaço, ou o próprio espaço como objeto de consumo, e:

\begin{abstract}
...isso pode ser ilustrado pelo turismo, em que o próprio meio ambiente é consumido através da recreação, ou pela relocalização dos negócios devido a atratividades naturais. Assim, o próprio design espacial pode ser convertido em mercadoria, juntamente com a terra, algo que arquitetos, planejadores de cidade e turistas conheceram por algum tempo.
\end{abstract}

Desta forma, "... el suelo há pasado a ser un valor de uso a convertirse em valor de cambio. En esta transofrmación de tipo de valor es donde se han asentado los "negócios" que a lo largo del proceso caracterizan la producción de deste nuevo espacio social" (Sánchez, 1991, p. 230). A produção espacial não se caracteriza somente pela introdução de objetos que se relacionam diretamente com o turismo, mas ainda pela criação e/ou aprimoramento de infra-estruturas que também dão suporte à atividade de forma indireta, como as de saneamento básico, rede bancária, de segurança, transporte, comunicação, energia, entre outros.

Segundo Cruz (2003, p. 8), "o principal elemento que caracteriza o lugar turístico é o turista" [e] "nenhum lugar turístico tem sentido por si mesmo, ou seja, fora do contexto cultural em que promove sua valorização, em dado momento histórico". A autora cita o contexto cultural devido ao fato que o atrativo turístico e também a paisagem turística são construídos culturalmente; é a sociedade que atua neste processo de valorização, e cabe lembrar que "o que é considerado atrativo hoje pelo turismo não era no passado e talvez não seja no futuro. Como a cultura varia no tempo e também no espaço, o que é atrativo para alguns grupos de pessoas pode não ser para outros" (p.9). 
A produção dos lugares turísticos, conforme Silveira (1997, p. 36), é ainda conseqüência da publicidade ${ }^{9}$ que, no atual período histórico, cria "uma vocação de consumo que antecede à produção material e imaterial e que, ressaltando a oposição entre trabalho e não-trabalho, busca despertar a necessidade de lazer". Assim, a autora afirma que além da tecnoesfera (incorporação de acréscimos científicos, tecnológicos e informacionais ao meio geográfico) cria-se uma psicoesfera, que se trata do plano das idéias, do imaginário, do discurso e das imagens. É na manifestação desta psicoesfera que se dá a aptidão paisagística dos lugares turísticos ${ }^{10}(1997$, p. 37), produzindo lugares turísticos e também sendo capaz de determinar a sua desvalorização e/ou o seu fim. Sobre esta questão, Hiernaux Nicolás (1996, p. $46,49)$ afirma que "a força do imaginário, e os fortes interesses do mundo da produção, têm sido incentivos suficientes para introduzir elementos da cultura empresarial no mundo do turismo [e] de tal forma, o turismo cria, transforma, e inclusive valoriza diferencialmente espaços que podiam não ter 'valor' no contexto da lógica da produção". Sabe-se que o turismo demanda diversas infra-estruturas nos lugares (a tecnoesfera no lugar), e "essa produção material dos lugares é causa e conseqüência da produção imaterial do turismo. Assim, o lugar turístico torna-se um produto da ciência e da tecnologia, com um conteúdo informacional e ideológico, que é capitalisticamente comercializado" (Silveira, 1997, p. 37).

Pode-se dizer, portanto, segundo Silveira (op. cit.), que dois elementos da psicoesfera atuam na produção dos lugares turísticos: primeiro, a publicidade que, invadindo cada vez mais a sociedade no seu aspecto cotidiano, impõe a necessidade da fuga do mundo e da lógica do trabalho (e assim o tempo do não-trabalho é mercantilizado), e segundo, a aptidão paisagística dos lugares e os atrativos turísticos, ambos sendo uma construção cultural, determinada por parcelas da sociedade num dado momento histórico.

\footnotetext{
${ }^{9}$ Para David Harvey, "a publicidade e as imagens da mídia [...] passaram a ter um papel muito mais integrador nas práticas culturais, tendo assumido agora uma importância muito maior na dinâmica de crescimento do capitalismo. Além disso, a publicidade já não parte da idéia de informar ou promover no sentido comum, voltando-se cada vez mais para a manipulação dos desejos e gostos mediante imagens que podem ou não ter relação direta com o produto a ser vendido...” (2004, p. 259). Assim, "a publicidade, o rádio e a televisão, agindo sobre o tempo livre, condicionam as massas e suscitam vontades que logo são percebidas como necessidades" (Boyer, 2003, p. 149-150).

${ }^{10}$ É também a psicoesfera que determina os atrativos turísticos.
} 
Neste sentido, "a psicoesfera é mais abrangente que a tecnoesfera e, amiúde, impõe uma valorização anterior à chegada da tecnoesfera - no sentido de concretização de uma função turística. Daí a corrida dos lugares para ingressar nos roteiros do turismo global" (1997, p. 38).

Para Remy Knafou (1991) o lugar turístico pode ser "inventado" por personagens célebres, que lançam, popularizam um lugar, e também por viajantes, que relatam suas viagens e desta forma divulgam lugares, despertando o interesse de outros. Na verdade, o termo "invenção" utilizado pelo autor diz respeito ao fato de o lugar já existir anteriormente à prática turística; assim, o que se inventa, descobre, não é propriamente o lugar em si, mas uma outra utilização do lugar, ou seja, sua função turística. A invenção do lugar turístico consiste, portanto, numa nova leitura do território ${ }^{11}$, num duplo movimento: o primeiro reside num processo que transforma a utilização do lugar (poder subversivo do turismo) e o segundo, na incorporação de novos territórios ao lugar turístico, que se traduz no poder de "conquista" do turismo.

\section{TURISMO, TEMPO LIVRE E PRODUÇÃO DE NECESSIDADES}

A lógica do trabalho e a do não-trabalho também estão presentes na produção do espaço pelo e para o turismo, e estas, no dizer de Hiernaux Nicolás (1996, p. 39), estão na base da especificidade do espaço do turismo, que se relaciona a práticas que diferem da vida cotidiana, do mundo do trabalho, fazendo surgir outra cotidianidade.

O que se pode afirmar é que cada vez mais a lógica do trabalho e o mundo da mercadoria (da troca) se impõem sobre a lógica do ócio (o tempo livre $)^{12}$, esta última cada vez mais mercantilizada e programada, principalmente no que diz respeito ao turismo de massa, significativamente tomado e mediado pela lógica do mercado, à medida que "a lei do tempo como valor de troca e

\footnotetext{
${ }^{11}$ Uma vez que o lugar turístico é uma porção do território, construído culturalmente.

$12 \mathrm{O}$ tempo livre é um tempo em que somos instigados à prática do consumo, e só existe em função do seu par dialético: o tempo do trabalho. Para Jean Baudrillard, "o tempo constitui uma mercadoria rara, preciosa e submetida às leis do valor de troca. É o que se constata a respeito do tempo de trabalho,
} 
como força produtiva não se imobiliza no limiar do lazer, como se este escapasse miraculosamente a todos os constrangimentos que regulam 0 tempo de trabalho. As leis do sistema (de produção) nunca entram em férias" (Baudrillard, 1995, p. 163). Seguindo-se o mesmo raciocínio, a "inatividade", segundo Debord (2005), do tempo do não-trabalho,

"não está liberada da atividade produtora: depende dela, é uma submissão inquieta e admirativa às necessidades e aos resultados da produção. Aí não pode haver liberdade fora da atividade, e no âmbito do espetáculo toda atividade é negada, assim como a atividade real foi integralmente subtraída para a edificação global desse resultado. Por isso, a atual "liberação do trabalho", o aumento do lazer, não significa de modo algum liberação no trabalho, nem liberação em um mundo moldado por esse trabalho. Nada da atividade roubada no trabalho pode ser encontrado na submissão a seu resultado" (p. 22-23).

A lógica do mundo da produção está presente no "mundo do turismo", este representado por um espaço de consumo intensificado, tanto do próprio turismo (enquanto mercadoria) como de bens e serviços relacionados ou não ao lazer e ao tempo livre (marcado, cada vez mais, por um tempo programado, um tempo de consumo). Conforme Baudrillard (1995, p. 161), o tempo também é consumido como qualquer outro objeto, "submetido ao mesmo estatuto que todos os bens produzidos ou disponíveis no quadro do sistema de produção: o da propriedade, privada ou pública da apropriação, do objecto, possuído e alienável, alienado ou livre, e participando, como todos os objectos produzidos de modo sistemático, da abstracção reificada do valor de troca".

Assim, uma exigência está inscrita "no âmbito do tempo "livre": restituir ao tempo o seu valor de uso [...] uma vez que se encontra regulado na sua cronometria pela abstração total do sistema de produção" (Baudrillard, 1995, p. 161). Nas palavras de Oliveira (2001, p. 191), o tempo do trabalho e o do nãotrabalho:

...estão ligados à sobrevivência do capitalismo, não na forma desta ou daquela empresa, mas a reprodução das relações capitalistas de produção, seja através de sua expansão 
horizontal (abarcando áreas em que predominam relações nãocapitalistas) ou vertical (criando novas necessidades e privatizando práticas sociais).

O valor de troca passa a dirigir o uso, e como conseqüência (ou causa) deste processo, houve a criação do que Debord (2005, p. 33) chama de pseudonecessidades, ou seja, aquela produção ininterrupta de necessidades que não dizem respeito às necessidades vitais humanas, mas sim àquelas relacionadas intrinsecamente ao consumo (do tempo, de imagens, de mercadorias). Conforme Baudrillard (1995, p. 163),

O repouso, o descanso, a evasão e a distracção talvez sejam "necessidades", mas não definem por si mesmas a exigência própria do lazer, que é o consumo do tempo. O tempo livre consiste talvez em toda a actividade lúdica com que se cumula, mas é, antes de mais, a liberdade de perder o seu tempo e eventualmente de o "matar" e dispensar em pura perda. (Não basta, portanto, afirmar que o lazer está "alienado" porque se reduz ao tempo necessário para a reconstituição da força de trabalho. A "alienação" do lazer é mais profunda: não diz respeito à directa subordinação do tempo de trabalho, encontra-se ligado à própria impossibilidade de perder o seu tempo).

O tempo livre tornou-se uma mercadoria consumível. Segundo Debord (2005), "a imagem social do consumo o tempo, por seu lado, é exclusivamente dominada pelos momentos de lazer e de férias, momentos representados à distância e desejáveis por definição, como toda mercadoria espetacular" (p. 106). ${ }^{13}$ À respeito do tempo-mercadoria, diz o autor:

Em seu setor mais avançado, o capitalismo concentrado orienta-se para a venda de blocos de tempo "todos equipados", cada um constituindo uma única mercadoria unificada, que integrou um certo número de mercadorias diversas. Por isso, na economia em expansão dos "serviços" e dos lazeres pode aparecer a expressão "pagamento com tudo incluído" para o habitat espetacular, os pseudodeslocamentos coletivos das

\footnotetext{
${ }^{13}$ O termo "espetacular", utilizado pelo autor, diz respeito à sua tese sobre a "Sociedade do Espetáculo", presente em sua obra de mesmo nome, na qual Guy Debord descreve um momento da nossa história em que a sociedade se transforma em espetáculo, sendo este "o momento em que a mercadoria ocupou totalmente a vida social" (p. 30), ou ainda "o capital em tal grau de acumulação que se torna imagem" (p. 25). É o momento em que as imagens tornam-se mais importantes que os objetos, estes reduzidos (ou melhor, ampliados), no mundo da mercadoria, ao caráter quantitativo, sob um modo de produção aliado à publicidade e ao consumo.
} 
férias, as assinaturas do consumo cultural e a venda da própria sociabilidade sob a forma de "conversas animadas" e de "encontros com personalidades". Essa espécie de mercadoria espetacular, que evidentemente só pode existir em função da penúria das realidades correspondentes, também aparece entre os artigos que promovem a modernização das vendas, e pode ser paga a crédito (p. 105).

O turismo exerce também sua influência no mundo da produção, na medida em que os turistas têm certas exigências com relação ao consumo que realizam, e são eles os agentes que transferem os recursos de um mundo para o outro (do mundo da produção para o mundo do ócio), que alimenta desta forma setores econômicos, movem capital, e assim participam da acumulação capitalista. Portanto, "encontramo-nos em pleno foco do consumo enquanto organização total da vida quotidiana, enquanto homogeneização integral onde tudo está compendiado e ultrapassado na facilidade, enquanto translucidez de uma "felicidade" abstracta, definida pela simples resolução das tensões" (Baudrillard, 1995, p. 20). O lugar do consumo, segundo o autor, é a vida quotidiana (p. 25) e este relaciona-se, portanto, ao reino da psicosfera, no intuito de "solucionar as tensões" próprias do período técnico-científicoinformacional, onde cada vez mais as "necessidades" são produzidas.

A produção de necessidades (e a prática social do turismo inscreve-se nela), condicionada em parte à publicidade, está assentada num discurso que visa o aumento da produtividade e instiga a lógica do consumo, que não é somente "a lógica da satisfação, mas a lógica da produção e da manipulação dos significantes sociais" (Baudrillard, 1995, p. 59). Assumindo-se que o tempo do consumo é também o tempo da produção, o autor afirma que "o lazer é forçado na medida em que, por detrás da aparente gratuidade, reproduz fielmente todos os constrangimentos mentais e práticos do tempo produtivo e da quotidianidade escravizada" (p. 164); daí ocorre a programação do cotidiano no tempo-livre pelo turismo quando este define, a exemplo dos pacotes turísticos, o que se pode e o que não se pode ver, e a duração préestabelecida dos "momentos de contemplação". 


\title{
A CIRCULAÇÃO E O TURISMO
}

A circulação, que nos remete à idéia de acesso, fluxos, deslocamento, movimento, possui uma estreita relação com o fenômeno do turismo. Ela não está vinculada somente a pessoas e/ou mercadorias e produtos, mas também a idéias, valores, pensamento, palavras, informação, conhecimento. Esta questão foi abordada por Camille Vallaux (1914, p. 291), que afirmava também que a circulação é um fenômeno político (e não subordinada somente às trocas), uma vez que a via econômica não nasce senão depois da política: "... la via económica no nace sino después de la politica, porque á la sombra de la protección del Estado es como la circulación económica prospera y se desenvuelve". Porém, uma ressalva deve aqui ser feita, pois a obra de Camille Vallaux data de 1914, tempos de consolidação dos Estados territoriais e auge do Estado-Nação; a grande diferença para os dias de hoje é que quem dita as regras são as grandes corporações (política das empresas), e não mais fundamentalmente o Estado, o que implica que "a organização espacial das relações sob o capitalismo moderno tornou-se cada vez mais um produto de processos econômicos que políticos" (Gottdiener, 1993, p. 122). O Estado e o Capital possuem na atualidade uma relação simbiótica e de cumplicidade:

\begin{abstract}
A tensão entre a fixidez (e, portanto, a estabilidade) que a regulação do Estado impõe e o movimento fluido do capital permanece um problema crucial para a organização social e política do capitalismo. Essa dificuldade [...] é modificada pela maneira como o próprio Estado é disciplinado por forças internas (nas quais baseia o seu poder) e por condições externas - competição na economia mundial, taxas de câmbio, movimentos de capital, migração, ou, às vezes, intervenções políticas diretas de potências superiores. Por conseguinte, a relação entre o desenvolvimento capitalista e o Estado tem de ser vista como mutuamente determinante, e não unidirecional. Em última análise, o poder do Estado não pode ser mais nem menos estável do que o permite a economia política da modernidade capitalista. (Harvey, 2004, p. 105).
\end{abstract}

À medida que novos espaços vão sendo produzidos, a questão da localização também ganha importância, uma vez que nestes espaços, que podem inclusive manter relações entre si, desenrolam-se o movimento das coisas e, portanto, "aspectos como distância e/ou proximidade relativa de 
mercados, concentração e/ou dispersão das chamadas externalidades, passam a ser referenciais de primeira grandeza na determinação do "atrito" espacial nas relações econômicas e no empenho em minimizá-lo" (Martins, 2001, p. 2526). Sobre a questão da importância da localização e sua relação com a atividade turística, Chesnais (1996, p. 202) evidencia que:

\begin{abstract}
No caso do turismo, as vantagens de localização são representadas pela dotação em riquezas naturais (sol, mar, montanha etc.), bem como pelo valor do patrimônio cultural e histórico de um país (arquitetura, museus etc.). São esses fatores, e também as multinacionais especializadas, que determinam a capacidade de o país atrair turistas. Boa parte das atividades ligadas à indústria do turismo (hotéis e restaurantes, clubes de férias) são intensivas em mão-de-obra; é por isso que as multinacionais do setor obtêm consideráveis vantagens por sua localização em países que combinem atrações naturais com mão-de-obra barata.
\end{abstract}

A circulação apresenta-se como uma das bases da diferenciação espacial e da hierarquização e guerra dos lugares, e esta idéia de movimento / circulação espacial, associada ao turismo, não diz respeito somente ao fluxo de mercadorias, força de trabalho e serviços, mas também e, primordialmente, ao fluxo de pessoas, consumidores de uma mercadoria produzida: o espaço, na forma de territórios turísticos. No turismo, não é o produto/mercadoria que se desloca até os consumidores para a troca, mas sim o movimento contrário. A esse respeito, pode-se considerar que

O turismo é um tipo de consumo diferente dos outros, pois se realiza em outro local e não visa à satisfação de uma necessidade fundamental do homem: ele não é um dado da Natureza ou do Patrimônio Histórico, pois nenhum lugar é "turístico em si", nenhum sítio "merece ser visitado", como diz a literatura turística; o turismo é um produto da evolução sociocultural... (Boyer, 2003, p. 16).

Se o fenômeno do turismo "representa apenas uma parte de um imenso jogo de relações" (Cruz, 2003, p. 12), a idéia de totalidade tem que estar sempre presente e, para se analisar o turismo na sua totalidade, é preciso ter em mente pelo menos duas dimensões básicas: a de uma atividade produtiva e a de uma prática social (Cruz, 2001, p. 20). Não há como analisar um 
fenômeno fora do contexto de suas relações, uma vez que "sem relações não há fatos" (Santos, 2004b, p.15).

Tanto o turismo como a divisão do trabalho (motor da vida social) associam-se à idéia de totalidade, uma vez que estão em permanente movimento e mudança. A divisão territorial do trabalho produz a hierarquização dos lugares e, consequentemente, produz uma luta entre a divisão territorial do trabalho existente e a divisão territorial do trabalho que vem instalar-se, pelos agentes que utilizam variáveis passadas e impõem novas. O turismo é uma atividade com inúmeros aspectos contraditórios, de caráter seletivo e, portanto, excludente, que acaba por privilegiar algumas áreas em detrimento de outras. Estamos assim diante de um acontecer hierárquico, responsável pela introdução de um novo sistema de objetos e ações, "resultante das ordens e da informação provenientes de um lugar e realizando-se em um outro, como trabalho" (Santos, 2002a, p. 166).

Um acontecer hierárquico é capaz de produzir interdependências longínquas através de relações que independem da contigüidade espacial, podendo ser, portanto, pontuais, onde predomina "a primazia das normas, e a relevância aqui não é da técnica, mas da política"14 (Santos, 2002a, p.167). Além do acontecer hierárquico, Santos (op. cit.) evidencia que há, ainda, um acontecer homólogo e um acontecer complementar. Em suma:

O acontecer homólogo é aquele das áreas de produção agrícola ou urbana, que se modernizam mediante uma informação especializada, gerando contigüidades funcionais que dão os contornos da área assim definida. O acontecer complementar é aquele das relações entre cidade e campo e das relações entre cidades, conseqüência igualmente de necessidades modernas da produção e do intercâmbio geograficamente próximo. Finalmente, o acontecer hierárquico é um dos resultados da tendência à racionalização das atividades e se faz sob um comando, uma organização, que tendem a ser concentrados (Santos, 2002a, p. 167).

\footnotetext{
${ }^{14}$ Tendo-se em mente que técnica e política são os dois elementos constitutivos do espaço, conforme o pensamento de Milton Santos.
} 
$\mathrm{Na}$ relação do turismo com o espaço faz-se necessário, portanto, apreendê-lo enquanto processo, com o interesse no movimento geral da sociedade para assim apreender o movimento geral do espaço. 


\section{O CONTEXTO SOCIO-ESPACIAL DO TURISMO EM JERICOACOARA}

Antes de qualquer atividade turística, ou mesmo nas formas "primitivas" de turismo no local (década de 1970), Jericoacoara era apenas uma pequena comunidade de pescadores enraizada em território à beira mar, de passado indígena $^{15}$, na qual "o dinheiro nada valia, e tudo [...] era na base da troca"16. Segundo Lima e Silva (2004, p.36), no passado "os nativos só conheciam a pesca, o companheirismo, a vida pacata e calma, os valores e os costumes, sabendo e conhecendo o valor do uso do ambiente natural que os rodeava".

O local era de difícil acesso: o deslocamento era realizado através das dunas para se chegar à vila que, à noite, contava apenas com lampiões para a iluminação. Desta forma, chegar ao local já era, em si, uma aventura, pois não existiam transportes especiais e o trajeto muitas vezes era realizado a pé ou com animais (cavalos, jegues). Hoje, a história é outra, pois frente à lógica de valorização (capitalista) da terra à beira-mar,

...antigas comunidades pesqueiras marítimas [...]
transformaram-se em povoados litorâneos - caracterizados
pelo baixo percentual de moradores envolvidos com a pesca;
pelo aumento de moradores que se dedicam ao comércio
(bodegas, mercadinhos, padarias), "envolvidos" em atividades
de prestação de serviços domésticos para proprietários de
segunda-residência (caseiros, cozinheiras, faxineiras) e para
turistas (hospedagem, alimentação, entretenimento); pela
tendência ao distanciamento entre os que são o lugar e o
permanente convívio com "estranhos" à comunidade (uns
chegam e ficam, outros apenas passam horas e/ou dias e vão
embora). (Lima, 2002, p. 92-93).

Destacando-se como um dos principais destinos turísticos do estado do Ceará, Jericoacoara tem sido amplamente divulgada e visitada por turistas originados de praticamente todo o território nacional e do exterior, que chegam ao local, normalmente, via Fortaleza. Jericoacoara ocupou, em 1999, o quinto

\footnotetext{
${ }^{15}$ Índios Tremembés.

${ }^{16}$ Galvão, 1995, p. 90.
} 
lugar entre as praias cearenses preferidas pelos turistas que visitaram o estado naquele ano (excluindo o litoral de Fortaleza) e, em 2005, subiu para terceiro lugar, conforme quadro 1 :

\begin{tabular}{|l|c|l|c|}
\hline \multicolumn{4}{|c|}{ QUADRO 1 } \\
\multicolumn{1}{|c|}{ Praias preferidas pelos turistas, excluindo o litoral de Fortaleza } \\
\hline \multicolumn{1}{|c|}{ PRAIAS } & $\mathbf{1 9 9 9}$ & \multicolumn{1}{c|}{ PRAIAS } & $\mathbf{2 0 0 5}$ \\
\hline 1. Cumbuco & 19,2 & 1. Cumbuco & 16,1 \\
\hline 2. Canoa Quebrada & 15,3 & 2. Canoa Quebrada & 14,2 \\
\hline 3. Morro Branco & 11,7 & 3. Jericoacoara & 9,5 \\
\hline 4. Porto das Dunas & 9,1 & 4. Icaraí & 8,2 \\
\hline 5. Jericoacoara & 7,0 & 5. Morro Branco & 7,4 \\
\hline 6. Icaraí & 4,6 & 6. Prainha & 5,3 \\
\hline 7. Lagoinha & 6,3 & 7. Porto das Dunas & 4,8 \\
\hline 8. Praia das Fontes & 4,6 & 8. Iguape & 4,4 \\
\hline 9. Outras & 22,2 & 9. Outras & 30,1 \\
\hline TOTAL & 100,0 & TOTAL & 100,0 \\
\hline
\end{tabular}

Fonte: SETUR/CE, fevereiro de 2006.

Neste sentido, e a partir do processo de valorização / resignificação do lugar que se dá efetivamente no início da década de 1980, a atividade turística é a que predomina em Jericoacoara na atualidade, devido principalmente às suas características paisagísticas, de reconhecida beleza cênica, e também pelas ações de marketing e iniciativas público/privadas que deram suporte e condições ao desenvolvimento do turismo no local.

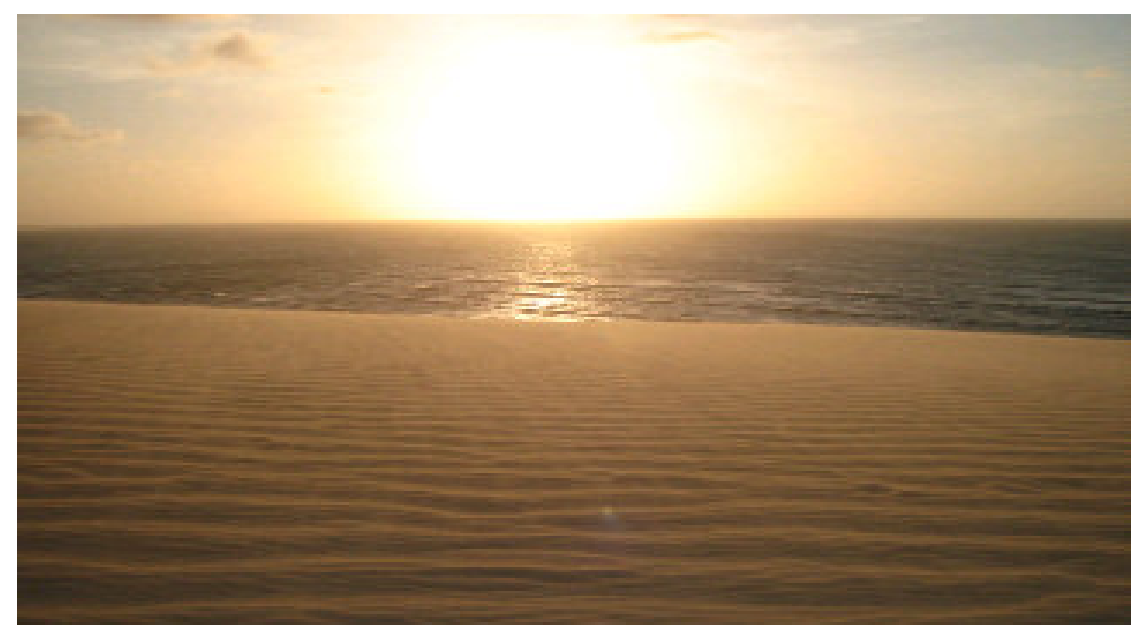

Fig. 1- Pôr do Sol em Jericoacoara (Fabio S. Molina, 2005) 


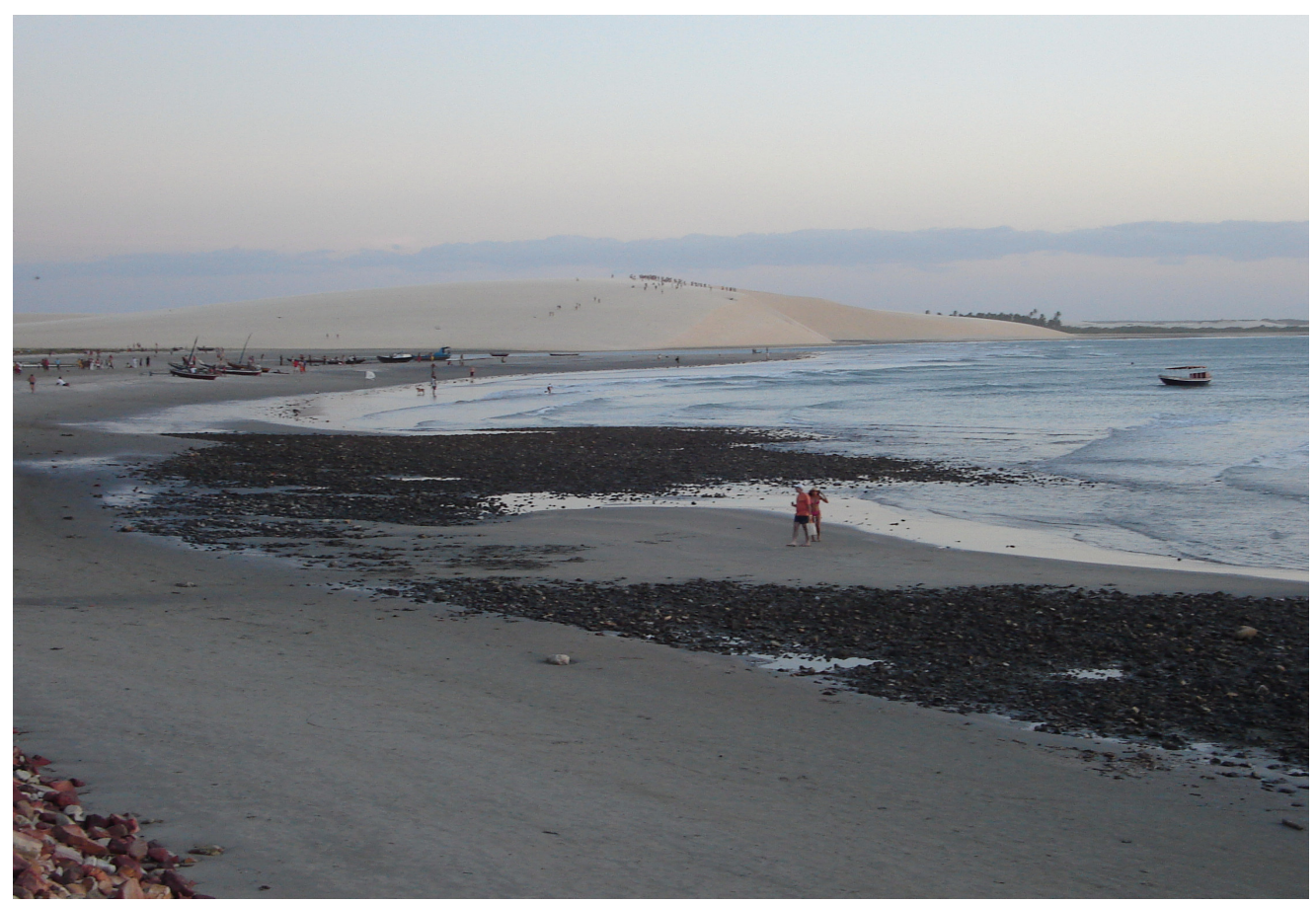

Fig. 2 - Praia de Jericoacoara e, ao fundo, a Duna do Pôr do Sol (Fabio S. Molina, 2005)

O turismo em Jericoacoara se insere no contexto de um turismo litorâneo e, também, de um turismo em áreas naturais; a natureza, em especial o litoral, apresenta-se como o principal objeto de consumo das formas de turismo ditas alternativas (ou seja, aquelas que se opõem ao turismo massificado). A esse respeito, Sánchez (1991) afirma:

Las condiciones físicas que ahora conforman un espacio litoral turístico han existido en si mismas siempre, pero no se les otorgaba anteriormente ni la valorización social, ni la posibilidad de usarlas. El clima, junto con el sol como factor esencial, en combinación con el mar y la playa, son elementos que conforman concretamente el ámbito físico del turismo de playa (p. 218).

$\mathrm{Na}$ atualidade parece haver uma preferência universal por ambientes litorâneos como espaços de lazer e, assim, a valorização das praias. Conforme Boyer (2003, p. 46), "a invenção turística do século 20 foi o turismo litorâneo, 
no Mediterrâneo e na Florida em 1900, pelos americanos”"17. Em áreas pouco ou não-urbanizadas, onde se dá o consumo da natureza, reconhece-se que esta modalidade de turismo "depende dos espaços urbanos, sob diversos aspectos" (Cruz, 2003, p. 69); daí a importância de Fortaleza como o portão de entrada de turistas no Ceará (e, consequentemente, para aqueles que chegam até Jericoacoara), juntamente com a implantação de infra-estruturas de circulação, hospedagem e restauração, essencialmente de características urbanas.

Vale ressaltar que os deslocamentos rodoviários no Ceará foram agilizados devido à ação intensa de melhoria dos acessos, o asfaltamento das estradas e a criação de vias estruturantes. Conforme Lima (2002, p. 67), "Fortaleza consolidou-se como ponto de recepção e de distribuição dos fluxos turísticos no litoral cearense. É "vendida" como cidade de belas praias: aquelas existentes nos municípios litorâneos. As projeções cartográficas difundidas pela SETUR $^{18}$ não mostram as reais distâncias entre a capital e as praias, estas sim verdadeiros cartões postais". Nesta citação, a autora evidencia um fenômeno comum sobre o turismo em algumas capitais nordestinas: o fato de praticamente toda a prática do turismo ocorrer em localidades litorâneas relativamente próximas das capitais, e não nelas mesmas, como é o caso de Maceió (Alagoas), que serve basicamente como dormitório para os turistas, que são direcionados às praias de outros municípios (como Maragogi). 0 mesmo ocorre no Ceará: muitos turistas hospedam-se em Fortaleza e frequentam as praias de municípios como Aquiraz e Aracati (neste último localiza-se a famosa praia de Canoa Quebrada), em passeios de um dia. Aos que visitam Jericoacoara, há ao menos um pernoite no local, pois a distância impossibilita o passeio de apenas um dia, com retorno à Fortaleza.

O fortalecimento significativo do turismo certamente dinamiza a economia de Jericoacoara, mas por outro lado, há sinais de desgaste

\footnotetext{
${ }^{17}$ Segundo o autor, no século XIX as estações balneárias e termais eram difundidas apoiadas no discurso médico, na qual a viagem era marcada por uma finalidade terapêutica e até mesmo como fuga de epidemias, como a cólera e a tuberculose. Da mesma forma, a valorização da natureza (sua construção ideológica) se deu na segunda metade do século XVIII, em contraponto à urbanidade da cidade, que "tornou-se a Babilônia moderna que pervertia, poluía, levava á perdição: numerosos textos do século 18 e da época romântica tinham um tom que podemos qualificar atualmente de ecológico” (p. 54).

${ }^{18}$ Secretaria do Turismo do Estado do Ceará.
} 
ambiental ${ }^{19}$, entre os quais a poluição de águas subterrâneas pela construção de fossas (uma vez que a vila ainda não possui um sistema de esgotos), o avanço acelerado de dunas sobre a vila (decorrente de sua desestabilização, motivada pela circulação de pessoas e automóveis), bem como a intensificação de alguns problemas sociais como prostituição (que ainda não ocorre de forma explícita), uso de drogas (principalmente o crack ${ }^{20}$, especulação imobiliária e, como alguns nativos costumam dizer, a perda de identidade da população local em função da "invasão" de turistas e de pessoas "de fora" que vêm estabelecer-se no local, em busca de trabalho. A identidade torna-se, portanto, produto da extensão da sociedade de consumo, cada vez mais mediada pelo mundo da mercadoria.

Jericoacoara localiza-se no litoral oeste do estado do Ceará, a $310 \mathrm{~km}$ da capital (Fortaleza), e a $19 \mathrm{~km}$ a leste da sede do município de Jijoca de Jericoacoara, do qual faz parte desde 1991. Segundo José Osmar Fonteles (2004, p. 131), "a 29 de junho de 1923, Jericoacoara foi elevada à categoria de Distrito por Lei Municipal ํo 94 [...]. Na época, pertencia ao município de Acaraú. Em 1985, passou a pertencer ao município de Cruz" tornando-se, até os dias atuais, distrito do município de Jijoca de Jericoacoara, criado pela Lei 11.796, de 6 de março de 1991.

\footnotetext{
${ }^{19}$ Acúmulo de resíduos sólidos, compactação do solo, soterramento de ecossistemas, manancais e fontes naturais, incremento na erosão do solo e praias, poluição visual e sonora, mudanças na circulação dos ventos locais e alterações no conforto térmico da vila (impactos microclimáticos).

20 Alessandro Gagnor Galvão (1995, p. 38) sintetiza bem esta questão com a seguinte frase: "O turista descobre a cajuína, o nativo descobre a cocaína".
} 


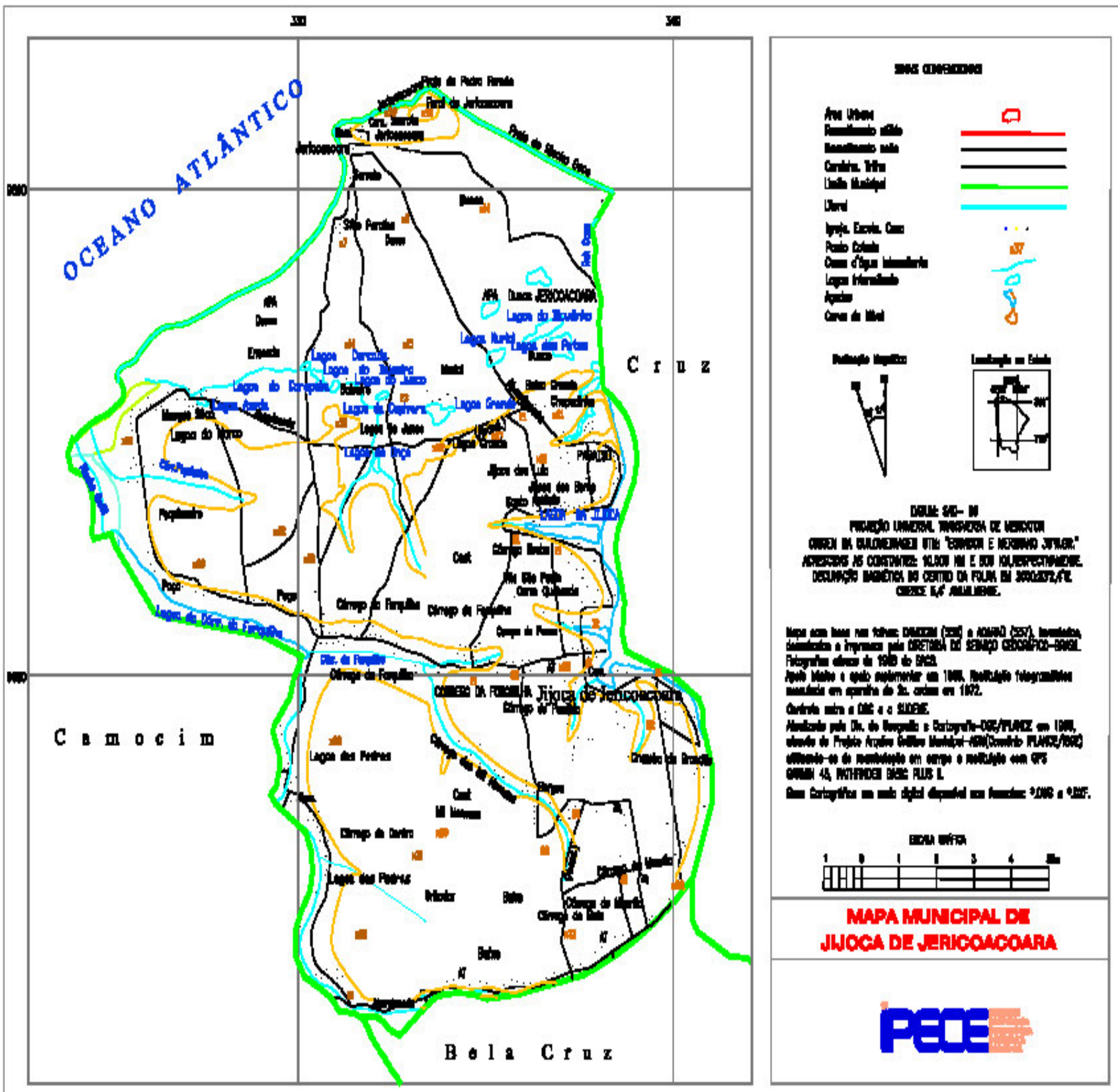

Mapa 1 - Mapa Municipal de Jijoca de Jericoacoara

Fonte: IPECE

Localizada em região costeira, sua paisagem é marcada por dunas fixas e móveis, tabuleiros ${ }^{21}$, restinga, serrotes (formação dunar - quartzito - fixada por vegetação mista de elementos do cerrado e da caatinga), lagoas, rios, enseadas, mangues, praias arenosas (com a presença de um ecossistema

${ }^{21}$ Situado em área arenosa (num pequeno planalto) com vegetação arbustiva e arbórea, apresentando alguns elementos do cerrado. 
favorável à reprodução de tartarugas marinhas), apresentando clima tropical chuvoso (quente e úmido com chuvas de verão e outono), com temperaturas máximas, em média, de $35^{\circ} \mathrm{C}$ o ano todo (principalmente em novembro e dezembro) e mínimas em torno de $22^{\circ} \mathrm{C}$ (principalmente em agosto).

$\mathrm{Na}$ área urbana, contém 8 ruas paralelas (interligadas por becos e ruelas) que se apresentam perpendicularmente à praia (fig. 3), onde encontrase um ecossistema antropogênico-cultural com a presença de árvores frutíferas e ornamentais, e outras espécies de características da vegetação do tabuleiro.

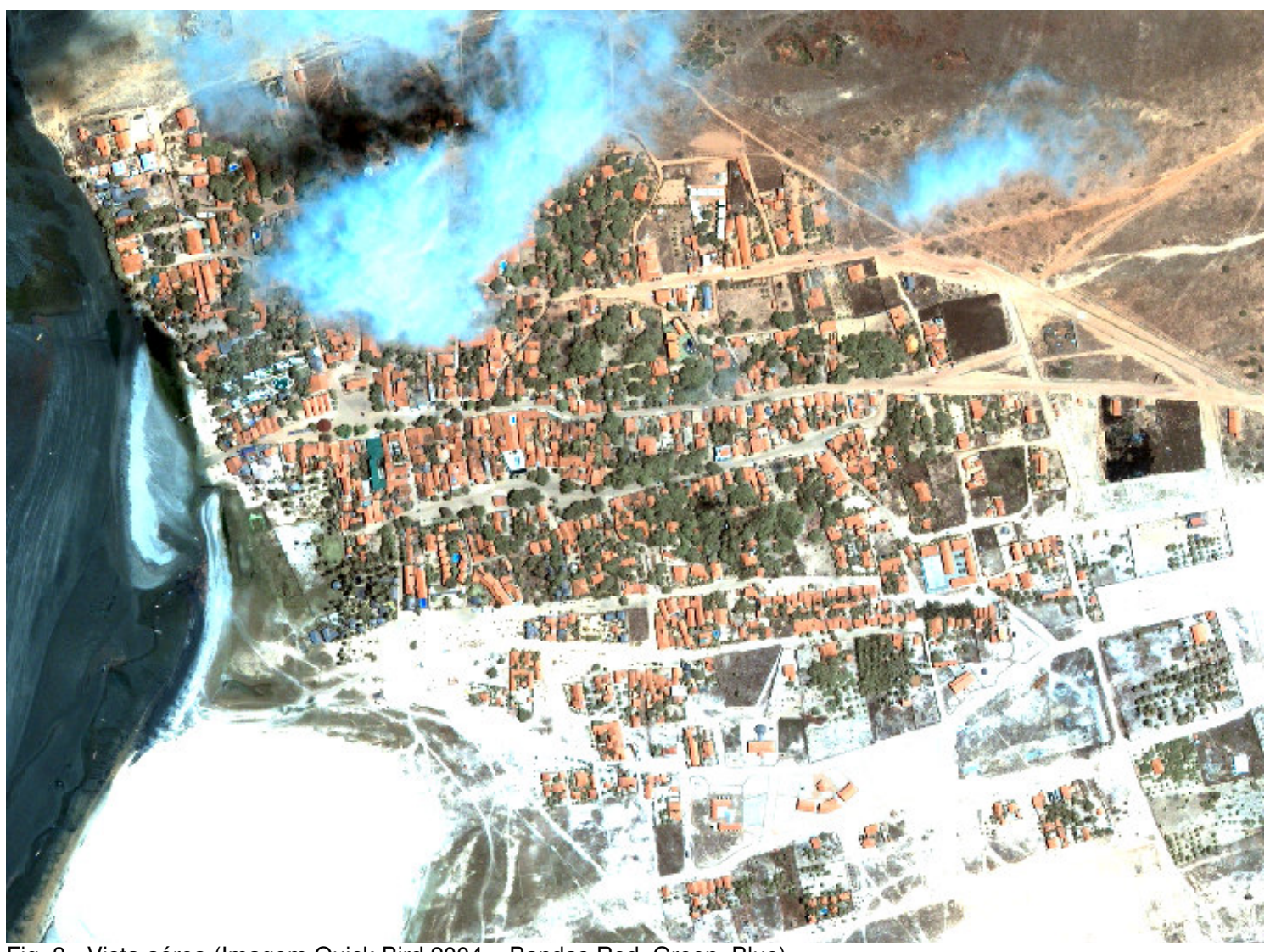

Fig. 3 - Vista aérea (Imagem Quick Bird 2004 - Bandas Red, Green, Blue) Fonte: SEMACE, 2004.

No que diz respeito à população, "até 1980 Jericoacoara contava com 731 habitantes, sendo 354 homens e 377 mulheres"22. Devido à evasão de boa parte da população jovem de Jericoacoara (por motivos aparentes de falta de emprego), em 1984 a população contava com 580 habitantes, sendo 48,8\%

\footnotetext{
${ }^{22}$ Fonteles, 2004, p. 131.
} 
deles com idade entre 0 e 15 anos $^{23}$. Nesta época, conforme estudo realizado pela UECE/NUGA (1985, p. 101), não havia "acentuadas divisões de classes, com uma população de características particulares e homogêneas nas suas atividades", e se constatou também a presença de "um grupo populacional predominantemente rural, onde suas atividades [estavam] voltadas para 0 extrativismo animal (pesca) aparecendo secundariamente as atividades: comércio, criação de pequenos rebanhos, a lavoura de subsistência e artesanato".

Conforme José Osmar Fonteles (2004, p.101), com a criação da APA de Jericoacoara (em 1984) e o aumento do fluxo turístico a partir daí, houve um retorno dos moradores à vila, provavelmente atraídos pelas oportunidades de trabalho proporcionadas pelo turismo no local. Desta forma contava, em 1989, com 650 habitantes $^{24}$ e, em 2000, com 950 habitantes (chegando a 1.300 na alta temporada $)^{25}$. Com base neste dado, pode-se afirmar que se trata, aqui, da presença de uma espécie de "população fixa flutuante" (com a presença de migrantes temporários).

Em 2006, a vila de Jericoacoara possui 2.328 moradores $^{26}$ e calcula-se que, em noites de reveillon, a vila chega a contar com cerca de 10.000 pessoas. Ou seja, uma multidão de turistas se dirige ao local, ressaltando a afirmação de Jean Baudrillard acerca da concentração turística, onde "foge-se do trabalho, mas não da concentração" (1995, p. 165), ou com base em Remy Knafou (1996), a simples constatação de que "gente atrai gente".

O município de Jijoca de Jericoacoara, incluindo-se a vila de Jericoacoara, apresenta os seguintes dados demográficos (quadro 2):

\footnotetext{
${ }^{23}$ UECE/NUGA, 1985, p. 101.

${ }^{24}$ Galvão, 1995, p.33.

${ }^{25}$ Fonteles, 2004, p. 132.

${ }^{26} \mathrm{Na}$ dificuldade de obtenção de dado confiável na Prefeitura Municipal de Jijoca de Jericoacoara (durante a pesquisa de campo), adotamos este dado obtido no website oficial do Governo do Estado do Ceará (www.ceara.gov.br), onde era noticiado, em 05 de maio de 2006, o início das obras de saneamento na vila de Jericoacoara e citava que as mesmas beneficiam diretamente os 2328 habitantes.
} 


\begin{tabular}{|l|l|}
\hline \multicolumn{2}{|c|}{$\begin{array}{c}\text { QUADRO 2 } \\
\text { População do Município de Jijoca de } \\
\text { Jericoacoara (1991-2005) }\end{array}$} \\
\hline Ano & Habitantes \\
\hline 1991 & 5.897 \\
\hline 1996 & 9.761 \\
\hline 2000 & 12.089 \\
\hline 2005 & 15.963 (estimativa) \\
\hline 2006 & 16.659 (estimativa) \\
\hline Fonte: IBGE e Fonteles (2004)
\end{tabular}

\begin{tabular}{|l|l|}
\hline \multicolumn{2}{|c|}{$\begin{array}{c}\text { QUADRO 3 } \\
\text { População da Vila de Jericoacoara (1980- } \\
\text { 2006) }\end{array}$} \\
\hline Ano & Habitantes \\
\hline 1980 & 731 \\
\hline 1984 & 580 \\
\hline 1989 & 650 \\
\hline 1991 & 731 \\
\hline 1993 & 818 \\
\hline 2000 & 950 \\
\hline 2003 & 1650 \\
\hline 2006 & 2328 \\
\hline Fonte: Galvão (1995) e Fonteles (2004)
\end{tabular}

O setor de serviços, impulsionado pelo turismo, é o que predomina no município (conforme o Perfil Básico Municipal elaborado pelo IPECE ${ }^{27}$, o setor de serviços é responsável por $81,9 \%$ do PIB municipal, a agropecuária 15,1\% e a indústria, em último lugar, responsável por 3,0\%), e as atividades econômicas principais da vila, antes do desenvolvimento da atividade turística, foram basicamente a pesca artesanal e a agropecuária.

\footnotetext{
${ }^{27}$ Instituto de Pesquisa e Estratégia Econômica do Ceará.
} 


\begin{tabular}{|l|l|}
\hline \multicolumn{2}{|c|}{$\begin{array}{c}\text { QUADRO 4 } \\
\text { Produto Interno Bruto no Município de Jijoca de } \\
\text { Jericoacoara, por Setor (\%), em 2005 }\end{array}$} \\
\hline Agropecuária & 15,1 \\
\hline Indústria & 3,0 \\
\hline ServiçoS & 81,9 \\
\hline
\end{tabular}

Fonte: IBGE/IPECE, 2005.

Por meio da Secretaria Especial do Meio Ambiente - SEMA, do Ministério do Interior, foi criada, em 1984, a APA de Jericoacoara ${ }^{28}$, com uma área de 5.480 ha $\left(54,8 \mathrm{~km}^{2}\right)$, situada entre as coordenadas geográficas $2^{\circ} 47^{\prime}$ a 2051' de latitude sul e 4024' e 4036' de longitude oeste, área esta dividida em oito sistemas de terras, onde o Sistema de Terra VIII (área urbana) corresponde à vila de Jericoacoara.

Os outros Sistemas de Terras (ST) referem-se as áreas do Serrote (ST I), Base do Serrote (ST II), Campo de Dunas (ST III), Praias (ST IV), Lagoas (ST V), Manguezais (ST VI) e Tabuleiro (ST VII). O Serrote trata-se de um acidente geográfico correspondente à uma formação dunar fixada por vegetação atingindo cerca de 98 metros de altura e sua importância reside no fato de proteger grande parte da vila de Jericoacoara da ação dos ventos e conseqüente avanço das dunas móveis além de servir como área de pastagem e ser um mirante natural (o Serrote abriga o Farol de Jericoacoara). As formações geológicas da APA remontam ao quaternário (restingas), terciário (tabuleiros) e pré-cambriano (serrote).

28 Área de Proteção Ambiental (APA), criada pelo Decreto Federal n. 90.379, de 29/10/1984. 


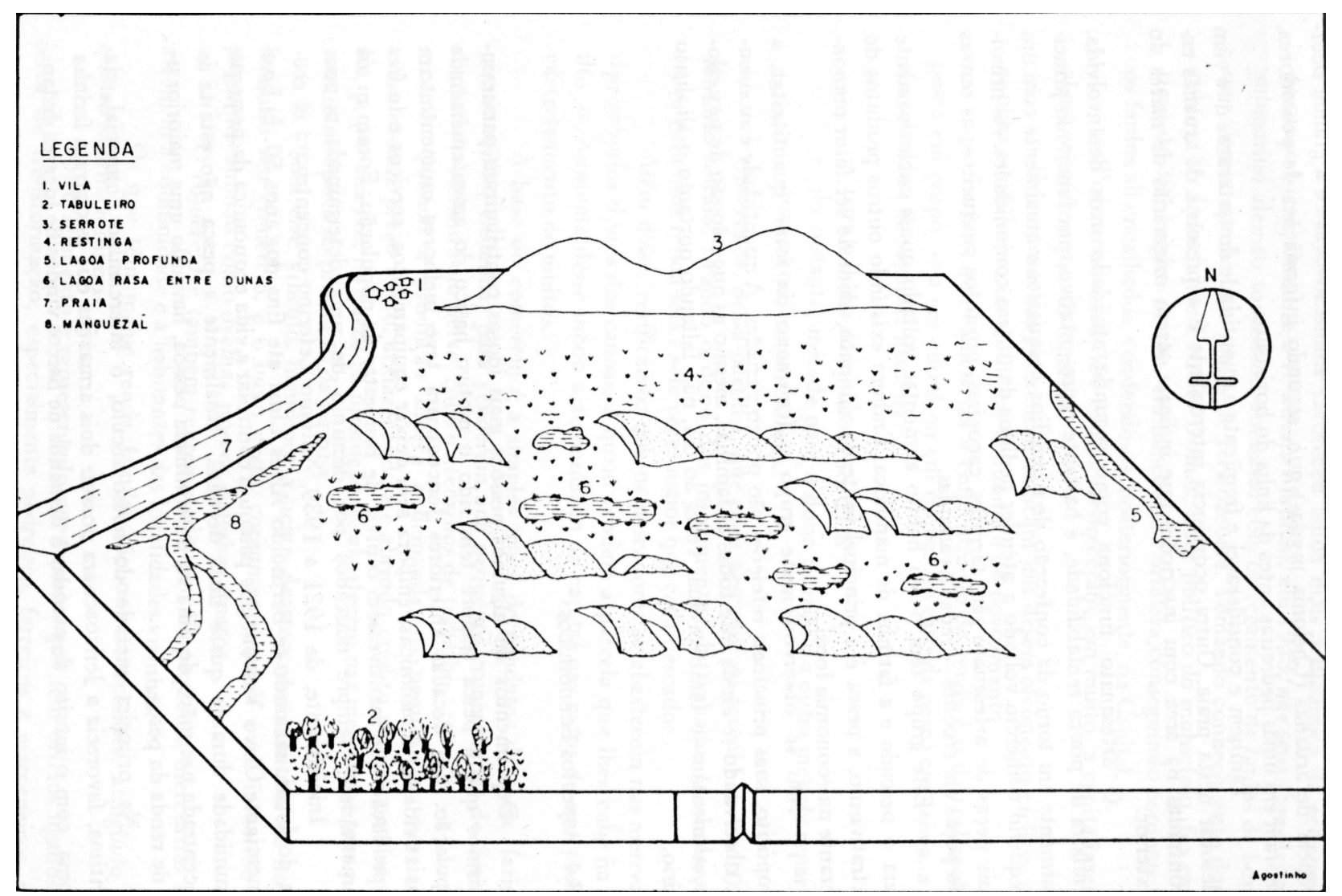

Fig. 4 - Perspectiva Espacial da APA de Jericoacoara (UECE/NUGA, 1985, p.100) 


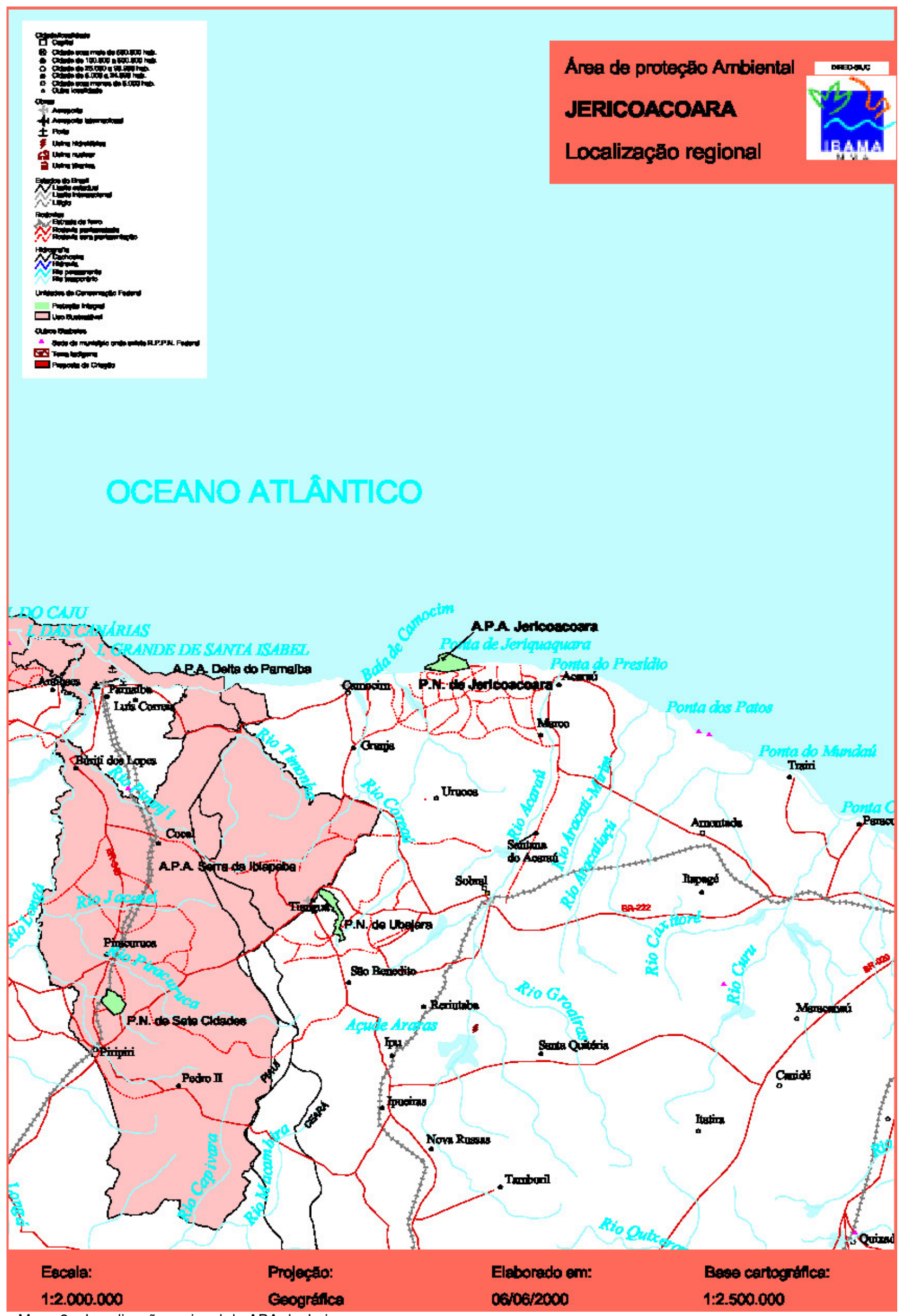

Mapa 2 - Localização regional da APA de Jericoacoara Fonte: IBAMA/CE 
UNIDADES DE CONSERVAÇÄO FEDERAIS DO BRASIL

Parque Nacional de Jericoacoara

IMA- MIHISTERD DO ИВO AMEERTE

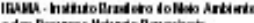

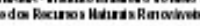

- Carta Imagem TM Landsat-

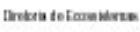

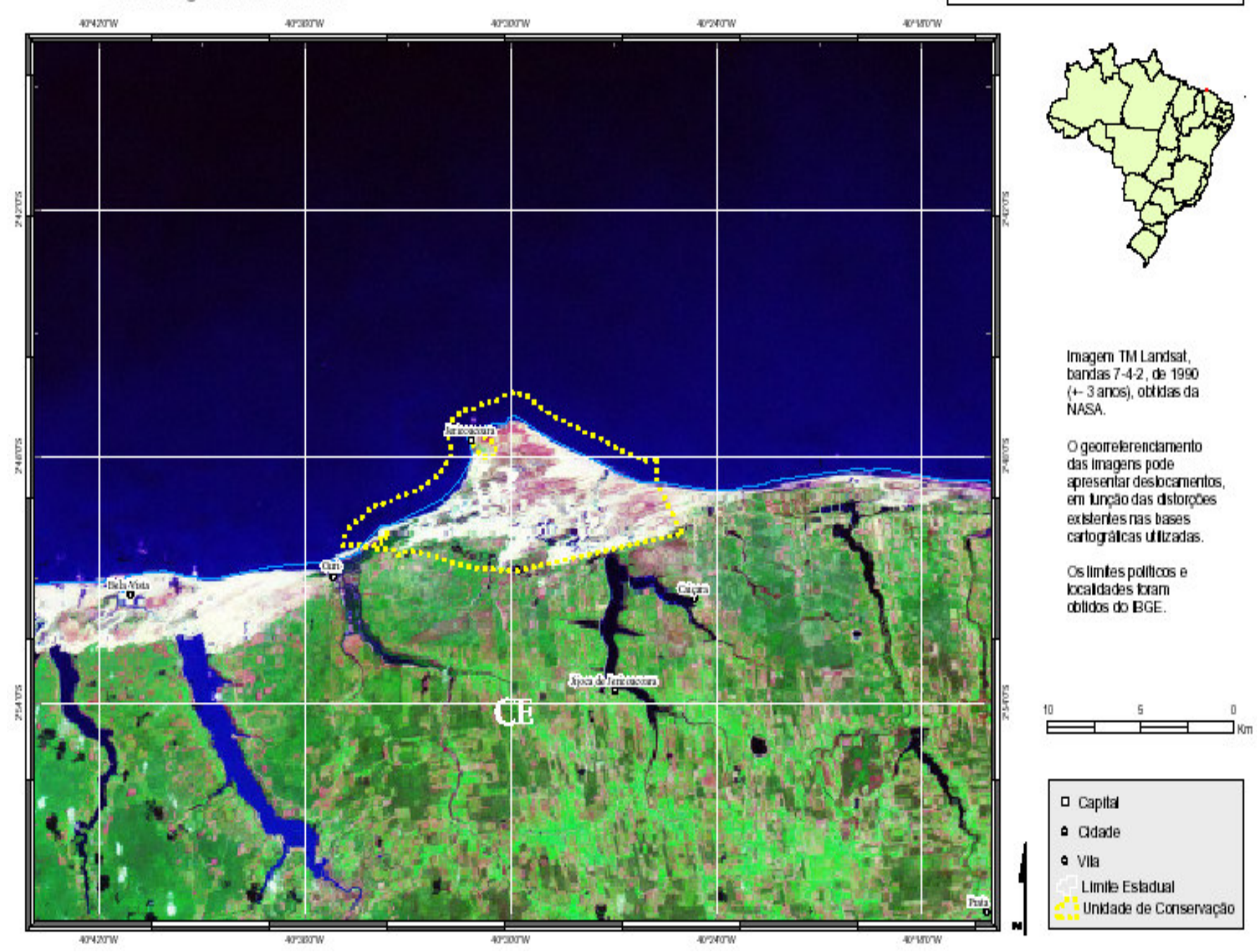

Mapa 3 - Localização do Parque Nacional de Jericoacoara Fonte: IBAMA/CE 


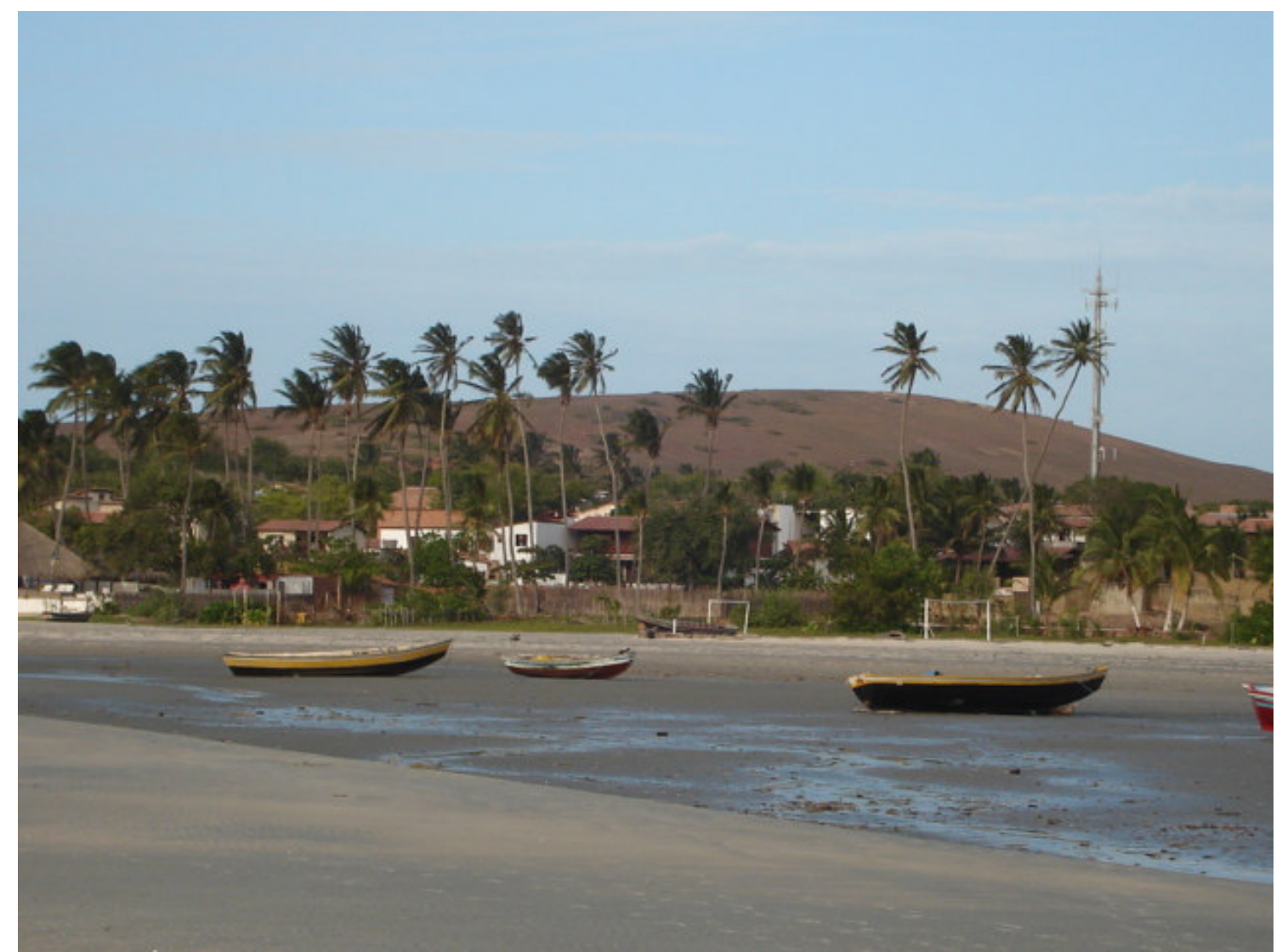

Fig. 5 - Vila de Jericoacoara e, ao fundo, o Serrote (Fabio S. Molina, 2005)

Recentemente, em 2002, quase a totalidade da área correspondente a APA foi transformada no Parque Nacional de Jericoacoara $(P A R N A)^{29}$, abrangendo os municípios de Cruz e Jijoca de Jericoacoara, e compreendendo uma área de 8.416 ha, administrada pelo Instituto Brasileiro do Meio Ambiente e Recursos Renováveis - IBAMA (que possui uma sede no local).

O Parque abarca basicamente o serrote, tabuleiro, lagoas e as áreas de dunas e mangues, deixando a área urbana (fig. 6), ou seja, a vila de Jericoacoara, de fora, já que, juridicamente, não é permitida a existência de residentes em Parques Nacionais; nos dias de hoje portanto, somente a vila (uma "ilha" cercada pelo PARNA) corresponde a APA, que agora diz respeito apenas ao Sistema de Terras VIII com seus limites redefinidos, ou seja, de 041 $\mathrm{km}^{2}$ para $0,78 \mathrm{~km}^{2}$, delimitados por uma poligonal cujo perímetro mede $3.525,33$ metros.

\footnotetext{
${ }^{29}$ O Decreto Federal n.9492, de 4 de fevereiro de 2002 cria o Parque Nacional de Jericoacoara e redefine
} os limites da APA de Jericoacoara (apenas parte da APA é que compõe o Parque). 


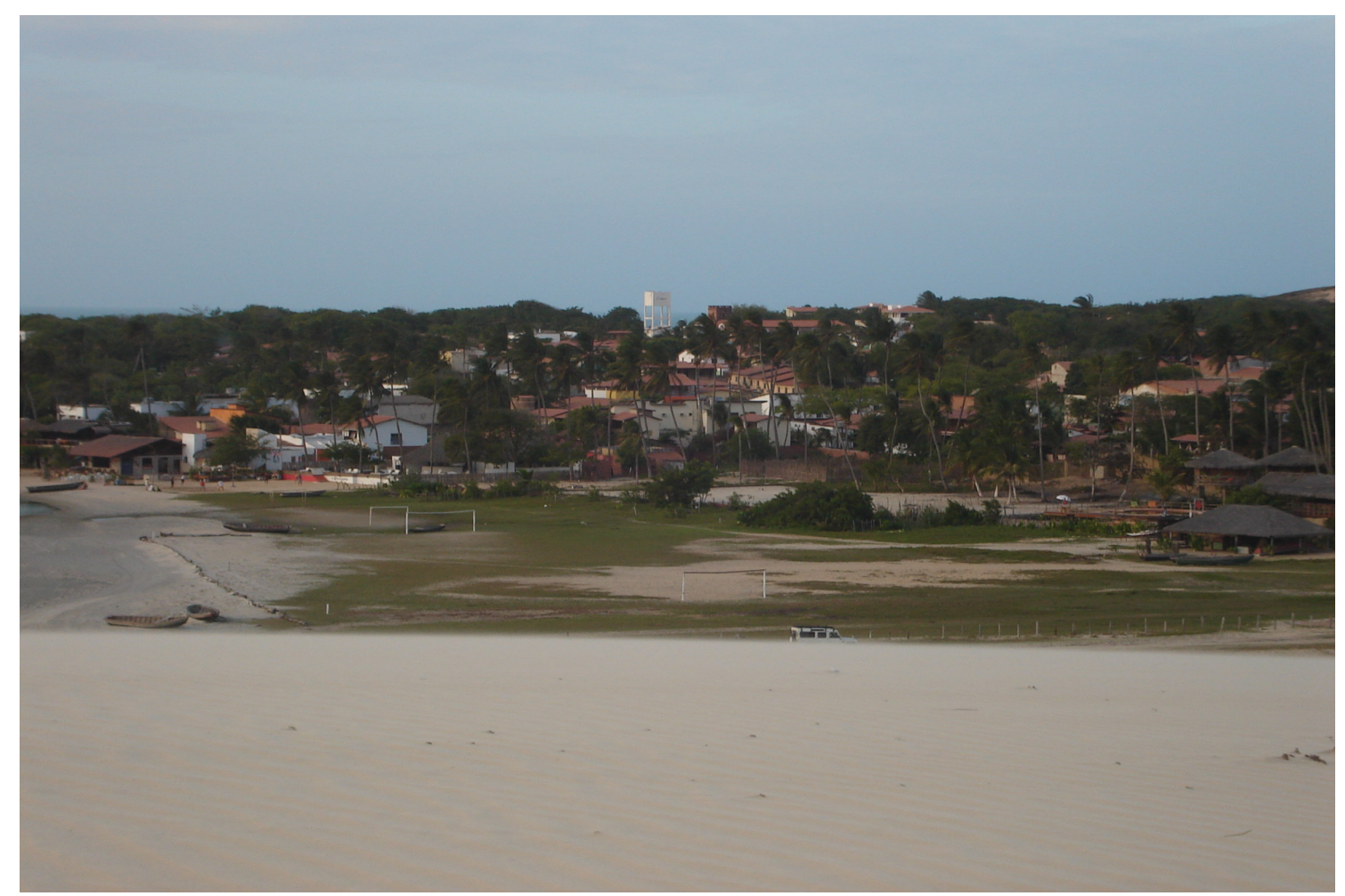

Fig. 6 - Vista parcial da área urbana da vila de Jericoacoara (Fabio S. Molina, 2005)

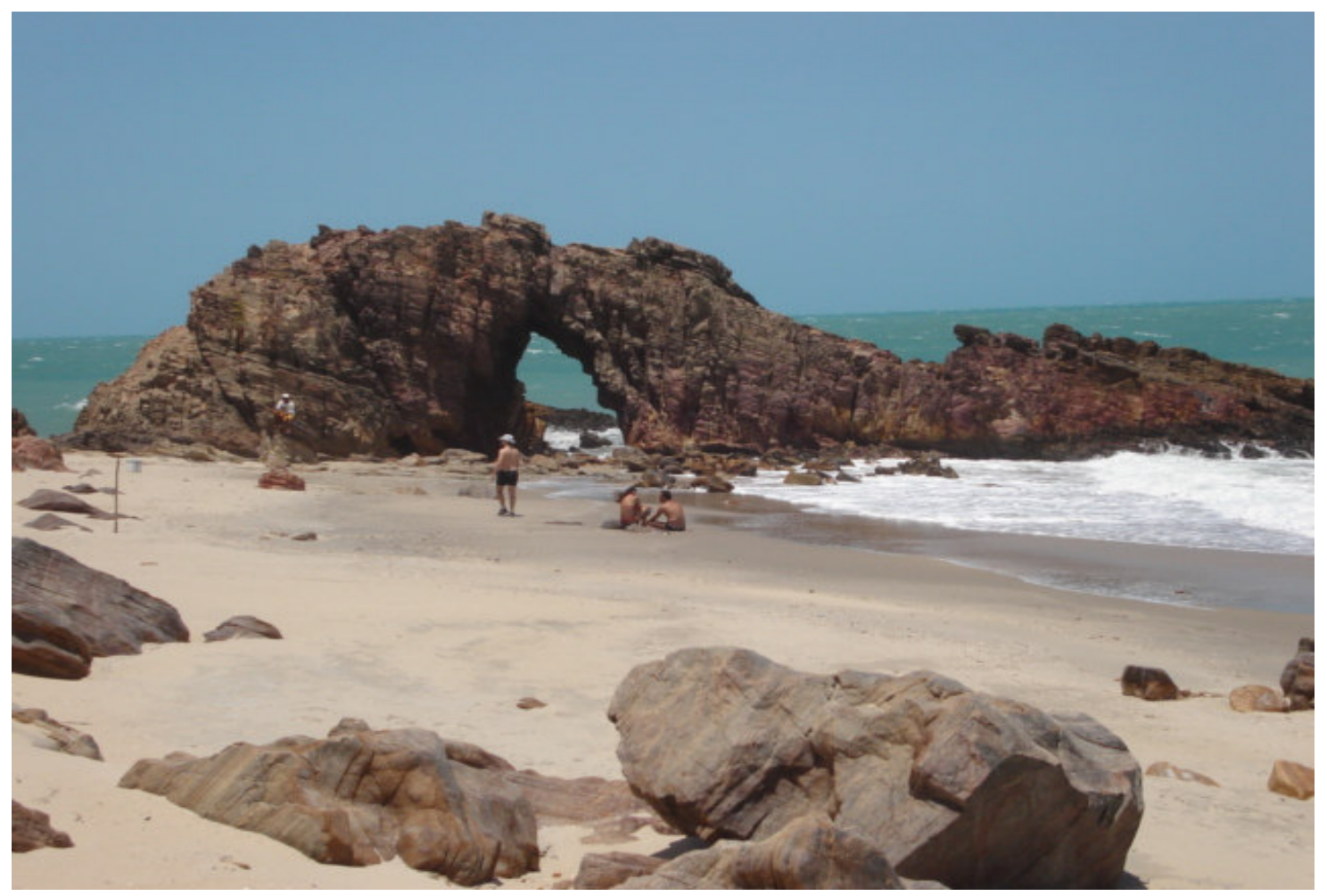

Fig. 7 - Pedra Furada (Fabio S. Molina, 2005) 
Tomando-se como referência o Sistema Nacional de Unidades de Conservação da Natureza - SNUC, Lei ㄲo 9.985, de 18/07/2000, e Decreto oㅜ 4.340 de 22/08/2002, Fonteles e Silva (2006, p.11) afirmam:

O Parque Nacional (Parna) - o caso de Jericoacoara - tem como objetivo básico a preservação de ecossistemas naturais de grande relevância ecológica e beleza cênica possibilitando a realização de pesquisas científicas e o desenvolvimento de atividades de educação e interpretação ambiental de recreação em contato com a natureza e de turismo ecológico.

Já, uma Área de Proteção Ambiental (que também é o caso de Jericoacoara) permite um certo grau de ocupação humana e tem como objetivo básico, além a proteção da diversidade biológica, "disciplinar o processo de ocupação e assegurar a sustentabilildade do uso dos recursos naturais" (op. cit, p.11).

Apesar da preservação do PARNA estar assegurada por leis, conforme Lima (2003 p. 4) "no Parna, atualmente pode ser encontrado um número aproximado de 6.000 animais domésticos, tráfego indiscriminado de veículos automotores, os quais formam trilhas diversas, afetando a fauna, flora, lagoas e dunas. Encontra-se, ainda, aproximadamente 58 famílias que vivem da agricultura de subsistência, utilizando desmatamentos e queimadas para 0 plantio".

Para se chegar a Jericoacoara, a partir da sede do município de Jijoca de Jericoacoara, transita-se cerca de $19 \mathrm{~km}$ (principalmente com automóveis de tração 4x4), passando pelo Parque, em áreas onde a circulação é permitida. 


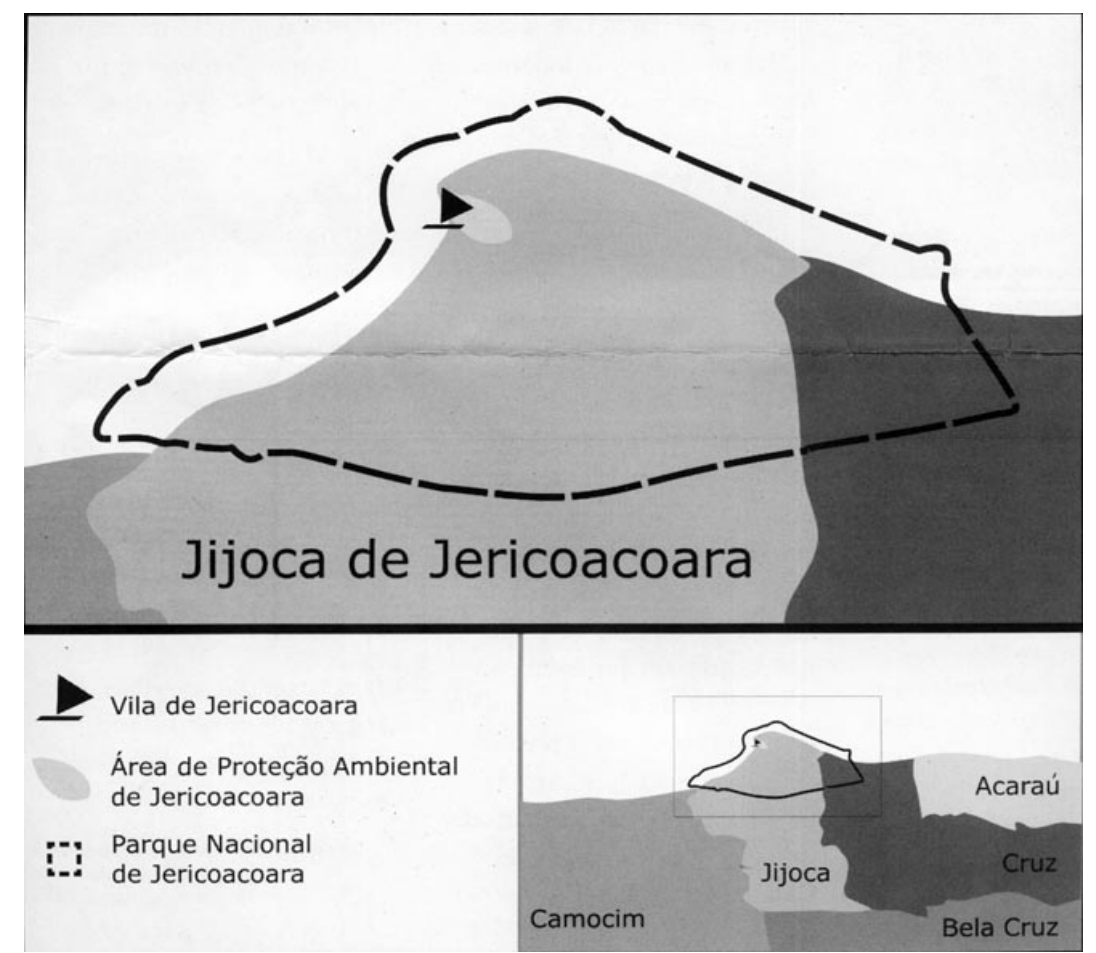

Fig. 8 - Localização da vila, APA e do PARNA de Jericoacoara

Fonte: Jornal "Jeri Jovem" (vila de Jericoacoara, ano 0, n.1, jan./fev. 2004).

\begin{tabular}{|l|l|}
\hline \multicolumn{2}{|c|}{ QUADRO 5 } \\
Transporte Utilizado pelos & Turistas (\%) \\
\hline Ônibus & 65,4 \\
\hline Carro & 26,7 \\
\hline Outros & 7,9 \\
\hline Total & 100 \\
\hline
\end{tabular}

Fonte: SETUR/CE, Pesquisa Direta - Fevereiro de 2005

Como se pode atestar com base no quadro 5 , a principal opção utilizada pelos turistas quanto ao meio de transporte para se chegar a Jijoca de Jericoacoara é ônibus, seguido de carro particular e por último, avião e/ou moto ("outros"), cabendo ressaltar que são inúmeras as agências de viagens localizadas em Fortaleza que promovem fretamentos rodoviários para o local. É bastante comum a interceptação dos turistas nos calçadões da Praia do Meireles (principalmente na Avenida Beira Mar) por parte destas agências, 
oferecendo diferentes passeios e pacotes para as praias cearenses, entre as quais destaca-se Jericoacoara. 


\section{OS AGENTES DA PRODUÇÃO DO ESPAÇO LOCAL}

Uma contribuição teórico-metodológica acerca do papel do turismo na produção do espaço é feita por Remy Knafou (1996), ao citar os agentes de turistificação dos lugares, que são, segundo o autor, turistas, mercado e planejadores e promotores territoriais. Não se pode, porém, descartar a idéia de os moradores de localidades receptoras do turismo serem também mais um entre esses agentes, atuando algumas vezes como empreendedores ou exercendo a sua função no âmbito da contra-racionalidade às determinações hegemônicas, função esta marcada por conflitos pelo uso do espaço que, no dizer de Seabra (1994, p. 16)

... estaria a revelar a essência do processo social: a propriedade lutando contra a apropriação concreta de um tempo e de um espaço. O espaço apresentado como dado sobre o qual se inscreveu a história da sociedade que o tomou por objeto, integrando-se ao processo de valorização pelas cadeias de equivalência como propriedade, é objeto de lutas encarniçadas. Isto delimita os problemas relativo ao território e as múltiplas territorialidades para cada um e para todos. Há uma dimensão da territorialidade que se liga ao vivido sem 0 que não há vida. A propriedade com toda veemência mostra sua impossibilidade. Por isso é preciso circunscrever, prescrever as territorialidades, o que não se dá sem contradição: a formalização da exclusão, a não propriedade. Este conflito no e como espaço vai gestando territorialidades novas.

Torna-se válida, portanto, uma análise do comportamento desses agentes de produção de espaços pelo/para o turismo, no intuito de auferir qual o papel de cada um na dinâmica do uso do território. Torna-se essencial também a constatação de como o turismo, através desses agentes, se relaciona com os elementos constitutivos do espaço, apoiados num esquema de análise fundamentado numa teoria maior (a do espaço), e buscando-se assim as categorias de análise pertinentes à sua compreensão.

O fenômeno do turismo deve ser entendido como parte de uma totalidade em movimento, e esta pressupõe que vivemos um período histórico 
no qual "as relações sociais que regem as atividades associadas ao espaço precisam adequar-se à forma pela qual o espaço é usado para adquirir riqueza" (Gottdiener, 1993, p. 129), ou seja, estamos acima de tudo inseridos na lógica da reprodução capitalista e, desta forma, o local, o lugar, se (re)adequa a esta lógica.

Apesar da mundialização dos mercados, não se pode desconsiderar os particularismos, pois existe um poder local de reação (Santos, 2004, p. 23). Estes particularismos também são importantes agentes de produção espacial e, no caso do turismo, uma análise que desconsidera o poder de organização dos habitantes, por exemplo, certamente será inconsistente.

Cabe lembrar que a produção do espaço também se verifica na luta de classes, entre quem é hegemônico e quem é hegemonizado, uma vez que "com o desenvolvimento das forças produtivas e a extensão da divisão do trabalho, o espaço é manipulado para aprofundar as diferenças de classes" (Santos, 2004a, p. 32).

\subsection{OS HABITANTES LOCAIS}

Conforme Lima (2002, p. 86), no passado, terras à beira-mar "não eram consideradas áreas propícias à produção econômica - mas que na contemporaneidade tornaram-se muito valorizadas e possuidores de estratégias e potencialidades de uso para a sociedade (devido à incorporação da maritimidade com referência de descanso e lazer)". Esta afirmação pode ser uma das bases sobre a qual se pode compreender as contradições sociais presentes em Jericoacoara e a presença, portanto, de resistências no local.

Os moradores da vila possuem atualmente um Conselho Comunitário, e já contaram com uma Associação de Moradores e uma ONG, chamada SOS JERI (organização não-governamental que atuou principalmente em denúncias contra os problemas sócio-ambientais no local, extinta desde 2002 
aparentemente por desentendimentos internos entre os membros). A vila conta com moradores nativos e moradores provenientes de outros lugares do Brasil e do exterior, entre os quais proprietários de pousadas e restaurantes (em sua maior parte vindos de outras localidades).

De acordo com levantamento realizado em setembro de 2003, Lima (2003, p. 4), constatou a presença de aproximadamente 1650 habitantes na vila de Jericoacoara, (podendo chegar a oito mil em alta temporada) ${ }^{30}$, sendo que do total de pousadas existentes nesta época, 25 eram de nativos e 80 de não nativos (incluindo estrangeiros). A vila contava, também, com uma escola municipal atendendo até o ensino médio, "um Posto de Saúde com atendimento insatisfatório, e um posto de vendas de medicamentos, um correio atendendo apenas postagem de carta simples, diversos bares, restaurantes, casas noturnas, comércio com produtos artesanais, mercadinhos e padarias" (p. 4).

Desta forma, é incoerente a afirmação de que Jericoacoara ainda seja um vilarejo caracterizado por uma comunidade tradicional, como no passado. No dizer de Lima (2002, p.84), historicamente, as comunidades pesqueiras marítimas "caracterizavam-se por um processo de trabalho artesanal que se dá no mar (a exemplo da pesca de peixe, da arraia e da lagosta) [...], e, em terra, com a realização de trabalhos artesanais (bordados, labirintos, rendas, fabricação e reparos dos artefatos de pesca) e manuais (pequenos plantios de subsistência e o extrativismo vegetal". No caso de Jericoacoara, inclui-se nestas atividades a criação de pequenos animais.

Com o desenvolvimento do turismo, a comunidade passa a ter um outro tipo de relacionamento (de vida) com os outros e com o local, e suas práticas cotidianas são profundamente transformadas. Aos poucos, as atividades de pesca, agricultura e criação de pequenos animais foram substituídas pelas atividades decorrentes do turismo; por exemplo, poucas embarcações restam na vila, e o peixe consumido é, em grande parte, proveniente da vizinha praia do Preá e do município de Camocim. Em entrevista concedida ao jornal "Diário

30 Atualmente (2006) estes números cresceram: há cerca de 2328 moradores e já se constatou aproximadamente 12.000 turistas no último reveillon. 
do Nordeste" (em 17/08/2003), relatando alguns dos principais problemas sociais presentes em Jericoacoara, o educador social Nelson Gomes Barbosa afirma:

\begin{abstract}
...a pesca praticamente desapareceu. Os pescadores e seus filhos deixaram a rede e o remo e passaram a ocupar outras atividades, quase sempre subempregos. Todas essas mudanças alteraram a vida dos nativos. Jericoacoara recebe gente do mundo todo, entretanto, o turismo na localidade continua desordenado, o que resulta em problemas para a comunidade nativa. Há nativos que acham que o movimento de turistas é muito bom. Mas, há outros que preferiam a tranquilidade dos velhos tempos. Tudo isso gera conflitos de identidade, porque ao mesmo tempo que chegou energia, água encanada e a própria televisão, a população perdeu a vida pacata, o silêncio e a própria convivência familiar que unia os nativos.
\end{abstract}

Trata-se, portanto, do que Knafou (1996, p. 64) define como "conflito de territorialidade", presente dualmente nos lugares turísticos: "a territorialidade sedentária dos que aí vivem frequentemente, e a territorialidade nômade dos que só passam, mas que não tem menos necessidade de se apropriar, mesmo fugidiamente, dos territórios que freqüentam". A visão positiva do turismo, por parte dos moradores locais, relaciona-se principalmente ao discurso do poder público (e ao senso comum) ao afirmar que o turismo gera renda, emprego e desenvolvimento local, visão esta que reflete diretamente na produção do espaço, uma vez que, conforme Gottdiener (1993, p. 220), "a transformação do espaço sempre se efetua através da ideologia do crescimento, especialmente sobre seus efeitos benéficos sobre os níveis de emprego".

A idéia de modernidade invade o cotidiano destas pessoas, que vêem, na atividade do turismo, uma possibilidade de mudança para melhorar a qualidade de vida e também para aumentar sua capacidade de consumo. Pode-se afirmar que tanto este comportamento local como o comportamento dos turistas, caracterizado fundamentalmente pela efemeridade do uso do tempo e do espaço, relacionam-se com a "modernidade" descrita por Harvey (2004, p.21): 
Ser moderno é encontrar-se num ambiente que promete aventura, poder, alegria, crescimento, transformação de si e do mundo - e, ao mesmo tempo, que ameaça destruir tudo o que temos, tudo o que sabemos, tudo o que somos. Os ambientes e experiências modernos cruzam todas as fronteiras da geografia e da etnicidade, da classe e da nacionalidade, da religião e da ideologia; nesse sentido, podese dizer que a modernidade une toda a humanidade. Mas trata-se de uma unidade paradoxal, uma unidade da desunidade; ela nos arroja num redemoinho de perpétua desintegração e renovação, de luta e contradição, de ambigüidade e angústia. Ser moderno é ser parte de um universo em que, como disse Marx, "tudo o que é sólido desmancha no ar ${ }^{\prime 31}$.

Os moradores se vêem ameaçados pela grilagem de terras e pela especulação imobiliária. Boa parte dos moradores nativos que venderam suas terras aos donos de pousadas e restaurantes deslocaram-se para uma área mais afastada da vila, dando origem a uma área de ocupação conhecida como a "Nova Jeri", que foi também formada por pessoas "invasoras", de muito baixa renda, que vinham de outras localidades próximas e construíam casas de taipa e palha para morar ${ }^{32}$. Estes nativos deslocaram-se basicamente por dois motivos principais: o primeiro deles diz respeito a propostas "tentadoras" dos investidores advindos de outras localidades (boa parte, por estrangeiros) e o segundo, pelo sentimento de que não conseguiriam competir com os novos empreendimentos instalando-se na vila.

Fruto da extensão da propriedade privada, a segregação revela que o acesso aos lugares da vida está submetido ao capital e, para este, os espaços de reprodução da vida são espaços improdutivos. A especulação imobiliária está diretamente relacionada ao consumo do espaço:

El precio del suelo será uno de los elementos importantes discriminadores de este proceso. A través de su análisis podremos entender la división funcional del espacio y su

\footnotetext{
31 O autor completa seu raciocínio sobre a modernidade ao definir também o momento da pósmodernidade, presente nos dias atuais, que tem como característica a "total aceitação do efêmero, do fragmentário, do descontínuo e do caótico [respondendo] a isso de uma maneira bem particular: ele não tenta transcendê-lo, opor-se a ele e sequer definir os elementos "eternos e imutáveis" que poderiam estar contidos nele. O pós-modernismo nada, e até se espoja, nas fragmentárias e caóticas correntes de mudança, como se isso fosse tudo o que existisse" (Harvey, 2004, p. 49).

${ }^{32} \mathrm{O}$ tipo original das casas em Jericoacoara era, desde o povoamento inicial da vila, caracterizado pela construção utilizando-se de pedras retiradas do Serrote.
} 
jerarquización, em cada área e interáreas. Em este aspecto asumen su importância los agentes proprietários de suelo, en cuanto que pueden aprovecharse del cambio de funcionalidad que generará benefícios en muchos casos ligados a unas ventajas de situación, sin que se haya producido valor. Este es el estricto sentido que cabe dar, como sabemos, al termino especulación, donde el suelo participa como valor de cambio sin generación de valor (Sánchez, 1991, p. 246).

Como medida corretiva, a Prefeitura de Jijoca de Jericoacoara e o Governo do Estado do Ceará, por meio da SDLR ${ }^{33}$, uniram esforços para a construção de moradias populares e promoveram a regularização fundiária na vila (no intuito de limitar a especulação imobiliária e as ocupações desordenadas), cuja última etapa deu-se em agosto de 2005, e privilegiava basicamente: a) que pelo menos um morador fosse residente em Jericoacoara há no mínimo 10 anos; b) famílias mais carentes, com renda mensal de até dois salários mínimos e c) que nenhum membro da família tenha sido beneficiado anteriormente por outros programas de habitação.

Conforme depoimento de alguns moradores locais, alguns barracos foram construídos apenas para que a área fosse demarcada, visando a regularização das terras para futura venda, uma vez que os terrenos em Jericoacoara estão super-valorizados. Desta forma, a "Nova Jeri" (localizada, inclusive, na rota de migração das dunas) conseguiu ser contida, juntamente com a expansão urbana irregular. Algumas residências presentes neste local sofrem, porém, com o avanço das dunas, como ilustram as figuras 9 e 10:

\footnotetext{
${ }^{33}$ Secretaria de Desenvolvimento Local e Regional.
} 


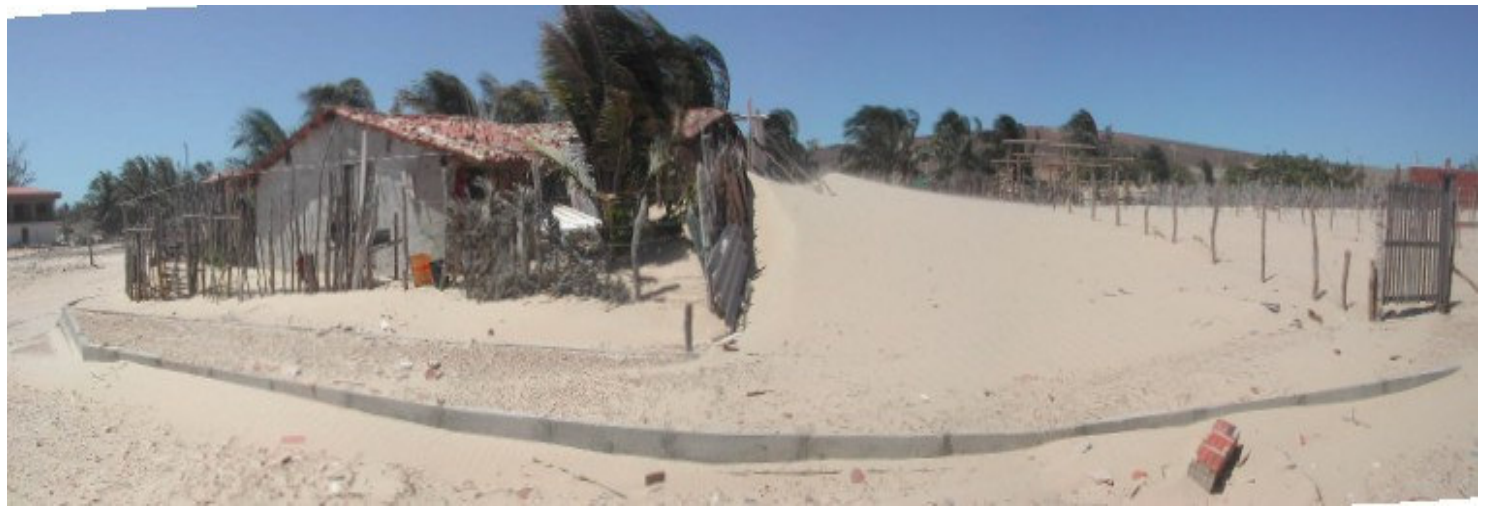

Fig. 9: Duna em direção à casa de taipa (Antonio Jeovah Meireles, 2005)

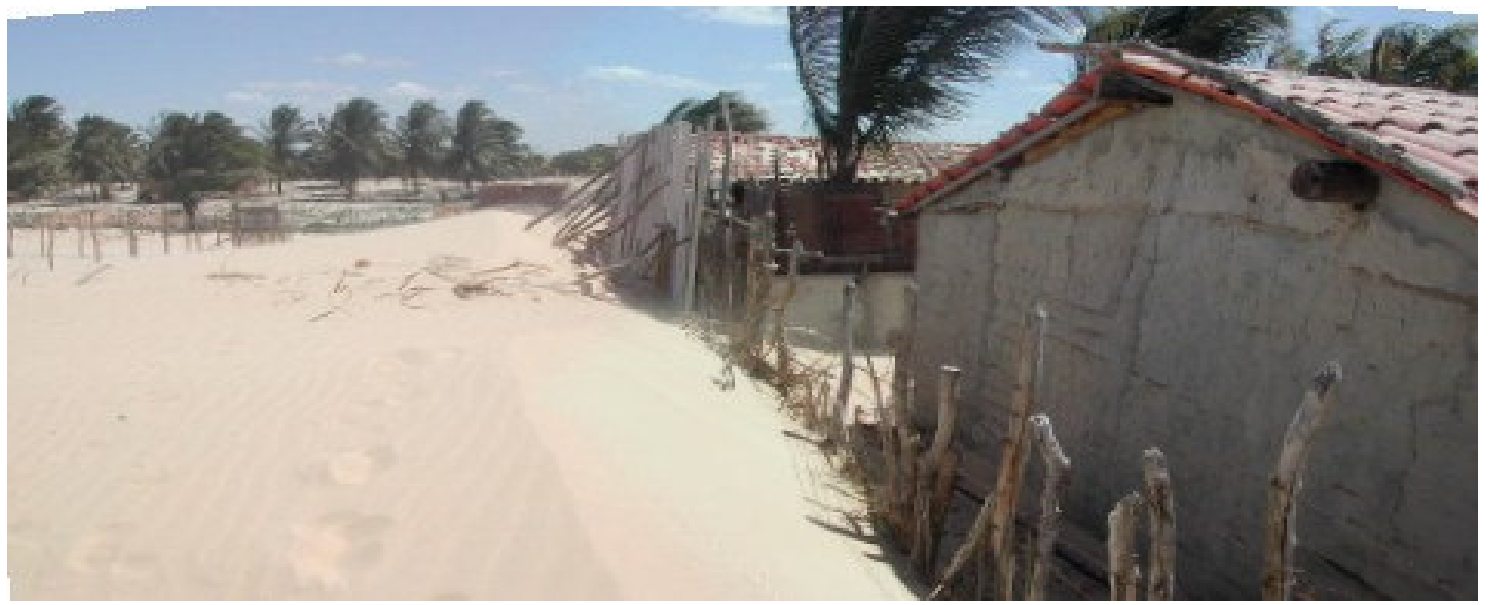

Fig. 10: O avanço das dunas alcança os limites da vila de Jericoacoara (Antonio Jeovah Meireles, 2005)

Coordenado pelo professor Antonio Jeovah de Andrade Meireles (Universidade Federal do Ceará - UFC), um trabalho de plantio de mudas nas áreas dunares impactadas tanto pela circulação de veículos como pela expansão urbana foi realizado em março de 2005, na forma de mutirão, contando com a participação da população local. Este trabalho teve o intuito de conter $\mathrm{o}$ avanço de sedimentos em direção à parte da vila $e$, assim evitar $\mathrm{o}$ acúmulo destes sedimentos nas vias de acesso, além de prevenir 0 soterramento de casas e prédios públicos. 


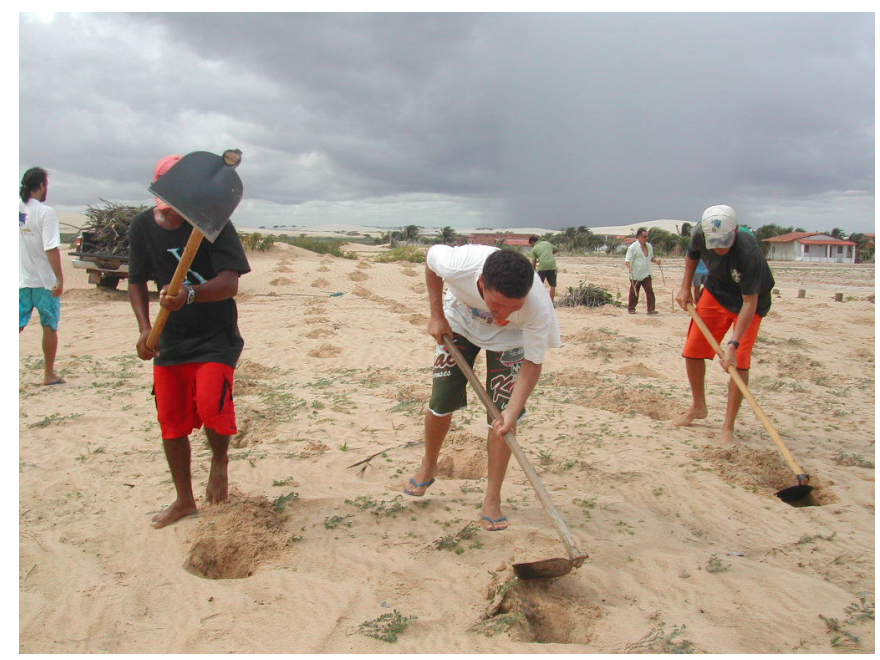

Fig. 11 - Plantio de mudas em áreas dunares (Antonio Jeovah Meireles, 2005)

Desde fevereiro de 1998, os habitantes de Jericoacoara organizados através do Conselho Comunitário (contando com o empenho da médica sanitarista Denise Cury), realizaram ações cotidianas de limpeza da vila e de praias, e implementaram um sistema de coleta e reciclagem de plásticos e vidros e de compostagem do material orgânico, frente à ineficiência do serviço público de coleta de resíduos sólidos no local. Com isso o Conselho Comunitário contou com a parceria do Ministério Público Estadual na erradicação de um lixão situado atrás da Duna do Pôr do Sol, em 1999. Porém desde o fim dos repasses dos recursos financeiros ao Conselho Comunitário por parte da SEMACE (Superintendência Estadual do Meio Ambiente) e da SOMA (Secretaria da Ouvidoria do Meio Ambiente), em 2002, este trabalho diminuiu sensivelmente.

Conforme depoimentos de membros do Conselho, a verba prevista para o trabalho de coleta seletiva, reciclagem e compostagem do lixo acumulado em Jericoacoara não foi liberada por razões políticas, uma vez que este Conselho não estava apoiando a candidatura de um deputado estadual no Ceará $^{34}$ e era visto, equivocadamente, como uma "facção política", considerando-se as denúncias feitas pelo mesmo sobre as irregularidades de obras que o Governo

\footnotetext{
${ }^{34}$ João Jaime Ferreira Gomes - PSDB
} 
do Estado vinha executando na vila ${ }^{35}$, através do Plano Diretor de Jijoca de Jericoacoara e o conseqüente Projeto de Requalificação Urbana da Vila de Jericoacoara (abordados mais profundamente no capítulo 4).

\title{
3.2. O MERCADO
}

O lugar turístico é capitalisticamente comercializado, e a apropriação pelo mercado ocorre, entre outras formas, com a introdução de elementos da cultura empresarial no mundo do turismo (Hiernaux-Nicolas, 1996). Cada vez mais a lógica do mercado e da mercadoria impõe-se à vida privada, inclusive no tempo do não-trabalho. Sobre esta questão, Martins (2001, p. 31-32) afirma que:

\begin{abstract}
Através da colonização insidiosa da vida privada, alcançada pelos circuitos de valorização, as malhas do mercado se estendem justamente até esse tempo que não se encontrava diretamente inserido nas tramas reprodutivas do capital. O que implica alienação, pois coações de toda ordem cada vez mais pesam sobre a vida, privando-a de capacidade criadora, e, portanto, de possibilidades de apropriação pelo homem da sua natureza. Isso se verifica, cabalmente, por exemplo, no consumo do espaço prescrito pela chamada indústria do turismo.
\end{abstract}

O mercado, representado pelas empresas, abarca, neste caso, agências de viagens, hotéis e pousadas, bares e restaurantes, e estabelecimentos comerciais e de serviços diversos que dão suporte aos turistas. Com o turismo, o espaço muda de função e converte-se num novo meio de produção, destinado a produzir novos valores de troca. Disso surge, no dizer de Sánchez (1991), uma nova aglomeração humana inserida nesta lógica, e assim novos

\footnotetext{
${ }^{35}$ Uma postura contestadora da sociedade (neste caso, por meio de uma entidade civil sem fins lucrativos, o Conselho Comunitário de Jericoacoara) pode causar certos desconfortos a uma parcela de representantes do poder público que viabilizam ações que vêm ao encontro de seus interesses. Estes, por sua vez, podem apresentar determinadas atitudes de repressão às "vozes que não querem se calar".
} 
serviços coletivos diversos são criados, como bares, retaurantes, comércios, lugares de distração, transporte, comunicação, etc., além da rede hoteleira, campings, pousadas. Segundo o autor,

Aun cuando el espacio litoral de ócio en sentido estricto sea un bien gratuito, la producción de los espacios necesarios complementarios conllevará, y efectivamente conlleva, la comercialización del tiempo de ócio al introducirlos en el circuito de mercantilización de unos servicios. La playa, el mar, el paisaje, el Sol y el clima pueden ser gratuitos, pero el alojamiento, la manutención, los servicios [...] imprescindibles para poder desplazarse y mantenerse, entra dentro de um circuito de producción-intercambio-consumo mercantilizado. ( $p$. 228).

Em Jericoacoara, há hoje um número considerável (devido ao pequeno tamanho da vila) de pousadas, restaurantes, bares, lanchonetes e algumas casas noturnas, responsáveis, entre outras coisas, pela poluição sonora no local $^{36}$.

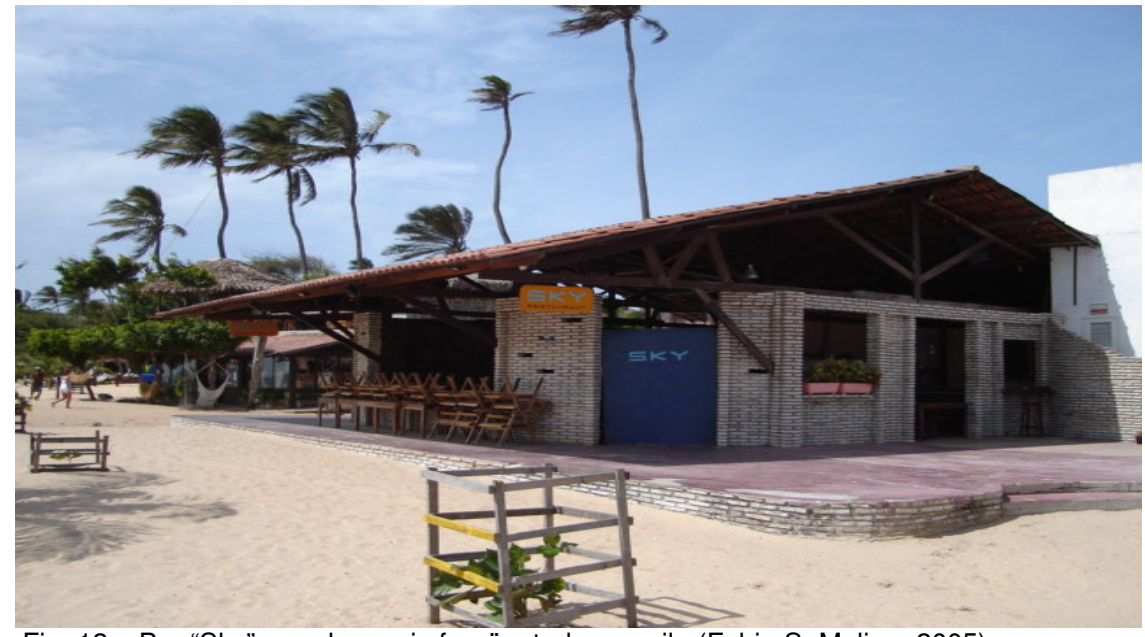

Fig. 12 - Bar "Sky", um dos mais freqüentados na vila (Fabio S. Molina, 2005)

\footnotetext{
${ }^{36}$ É possível, em qualquer parte da vila, ouvir-se o som do forró ou da música eletrônica, durante a madrugada.
} 


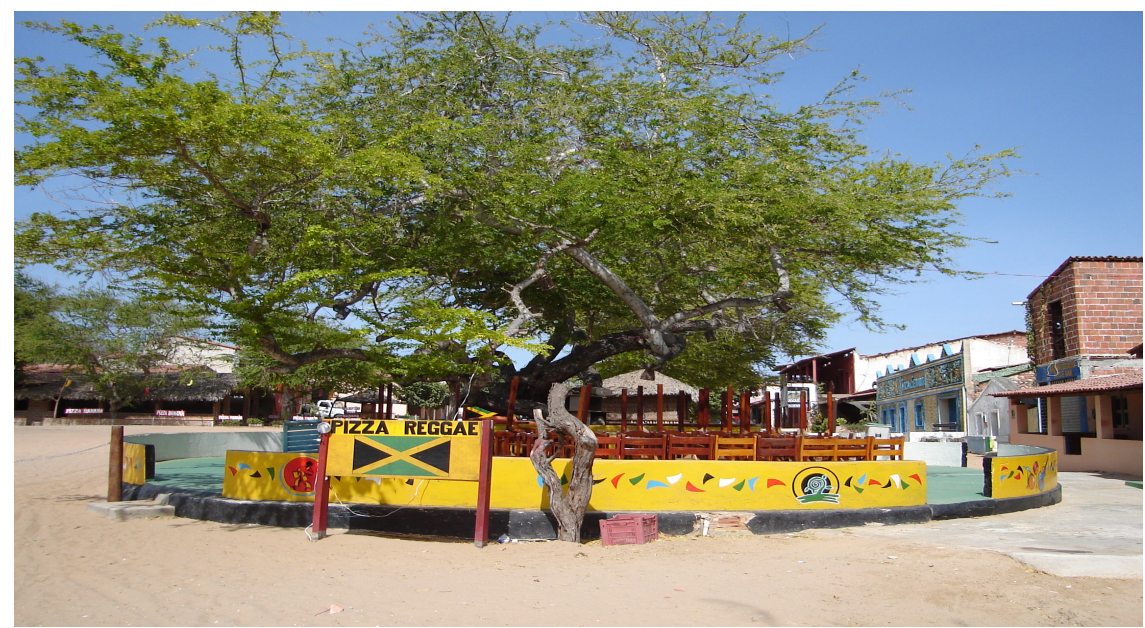

Fig. 13 - Pizzaria em local impróprio (Fabio S. Molina, 2005)

São muitas as agências de viagens em Fortaleza que promovem o destino turístico de Jericoacoara, oferecendo pacotes, em sua maioria de duas noites, incluindo transporte, hospedagem e alguns passeios de buggy pelas lagoas, dunas e pela vila vizinha, Nova Tatajuba. É grande o número de bugueiros, na vila, oferecendo-se para tais passeios e oferecem também, juntamente com donos de caminhonetes e moto-taxis, o serviço de transporte até a sede do município (comumente chamada somente de Jijoca).

A vila possui cerca de cinco agências de viagens que, de forma mais organizada, oferecem passeios de buggy e veículos off-road para localidades próximas ou mais distantes, como passeios que saem de Jericoacoara e vão até São Luis, no Maranhão, passando pelo Delta do Parnaíba (PI) e Lençóis Maranhenses (MA). A respeito da importância das agências de viagem na produção do espaço para o turismo, Sánchez (1991, p. 242) evidencia que

... los operadores turísticos ejercen una influencia esencial y condicionante, aunque sea indireta, sobre los agentes productores de espacio: 1) por cuanto controlan una parte importante del turismo extranjero [...]; 2) por cuanto son ellos los que eligen el espacio a consumir a través de sus ofertas; y 3) porque su posición en el mercado les permite imponer lãs condiciones que deben reunir los espacios de ocio para que sean aceptados, y así entrar a formar parte de su área de intervención. 
O comércio informal também é muito presente na vila. Durante o dia, é comum alguém ser abordado na praia com a venda de bijuterias, artesanatos e petiscos/doces caseiros, e à noite, no início da Rua Principal (próximo à praia), diversas barracas concorrem entre si e com os estabelecimentos fixos na venda principalmente de bebidas alcoólicas, a preços baixos.

Outra atividade que começa a ser explorada em Jericoacoara são os esportes náuticos, principalmente o windsurf e o kitesurf $f^{37}$, praticados em sua maioria por estrangeiros e pessoas de alto poder aquisitivo, por se tratar de atividades cujo aluguel dos equipamentos é, geralmente, alto.

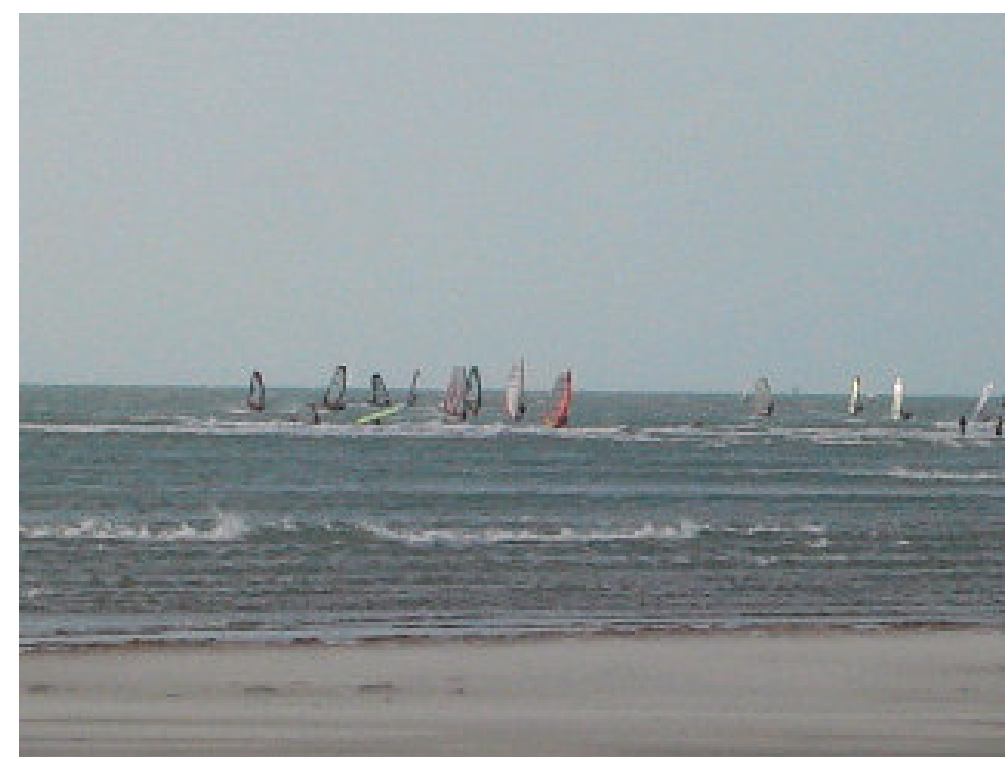

Fig. 14 - Prática do winsurf em Jericoacoara (Fabio S. Molina, 2005)

Pela disposição e velocidade dos ventos, Jericoacoara é muito procurada por adeptos a estes esportes, e já está sendo divulgada no exterior, em revistas especializadas, pelo proprietário do "Clube dos Ventos", estabelecimento que vende este serviço (aluguel de equipamentos e cursos

\footnotetext{
${ }^{37}$ Estes dois esportes utilizam-se de uma prancha parecida com a de surf, com uma estrutura de suporte para os pés; o windsurf é realizado à vela e o kitesurf, realizado com o que os adeptos chamam de pipa, "papagaio" ou, simplesmente, asa.
} 
para principiantes) e possui, na vila, um espaço de convivência, com restaurante e lanchonete. É curioso notar também o considerável número de massagistas na vila, tendo em vista a recomposição física dos esportistas ao final do dia. Surge, portanto, mais uma atividade em função da existência de outra.

Atualmente, a oferta hoteleira de Jericoacoara é composta de 71 estabelecimentos, 833 UHs (apartamentos) e 2.373 leitos. Segundo pesquisa realizada em fevereiro de $2005^{38}$, a capacidade instalada, em termos de UHs, apresentou a seguinte composição: hotéis $(14,9 \%)$ e pousadas $(85,1 \%)$.

\begin{tabular}{|l|l|l|l|l|l|l|}
\hline \multicolumn{7}{|c|}{ QUADRO 6 } \\
\hline \multirow{2}{*}{ Ostabelecimento } & Quantidade & \multicolumn{2}{l|}{ Uhs } & \multicolumn{2}{l|}{ Leitos } & \\
\cline { 2 - 8 } & № & $(\%)$ & № & $(\%)$ & № & $(\%)$ \\
\hline Hotéis & 5 & 7,0 & 107 & 149 & 269 & 11,0 \\
\hline Pousadas & 66 & 93,0 & 726 & 85,1 & 2.113 & 89,0 \\
\hline Total Geral & 71 & 100,0 & 833 & 100,0 & 2.373 & 100,0 \\
\hline
\end{tabular}

Fonte: SETUR/CE, Pesquisa Direta - Fevereiro de 2005.

Numa pesquisa realizada em 60 pontos de hospedagem ${ }^{39}$, incluindo campings e quartos avulsos, Nascimento (2001, p. 378) identificou que $85 \%$ dos meios de hospedagem não eram registrados pela EMBRATUR ${ }^{40}$.

No que diz respeito ao quadro de funcionários, este é composto, em sua maioria, pelos proprietários e seus familiares, que não possuem capacitação profissional. A pesquisa detectou ainda que somente $30 \%$ dos meios de hospedagem pertencem aos nativos, devido a grande maioria ter vendido ou sublocado seus estabelecimentos. Com efeito, são os estrangeiros e pessoas

\footnotetext{
${ }^{38}$ GOVERNO O ESTADO. Ceará. Secretaria do Turismo. Demanda turística de Jericoacoara. Fortaleza, fevereiro de 2005.

${ }^{39}$ Em 2001 haviam 39 pousadas em Jericoacoara, com 866 leitos, e para 2005, este número cresceu cerca de 69,23\%, num total de 71 estabelecimentos (porém, conforme o Conselho Comunitário, a vila apresenta atualmente um número maior - cerca de 110 pousadas -, diferindo dos dados da SETUR).

${ }^{40}$ Instituto Brasileiro de Turismo, vinculado ao Ministério do Turismo.
} 
vindas de outras partes do Brasil que se estabelecem como donos dos melhores pontos de serviços de Jericoacoara.

Conforme noticiado pela imprensa ${ }^{41}$, um levantamento feito no período de 1 de janeiro a 3 de março de 2005 pela Junta Comercial do Ceará detectou que, de um total de 39 empreendimentos estrangeiros ao longo do litoral cearense, 14 destes tiveram Jericoacoara como endereço. Italianos e portugueses detêm a maior participação dos investimentos estrangeiros no local, e quanto aos comerciantes brasileiros, não há sequer registros de iniciativas nacionais em equipamentos como hotéis, pousadas, restaurantes e bares abertos no período compreendido por este referido levantamento (cabe ressaltar que boa parte desses equipamentos localiza-se em terrenos à beiramar).

\subsection{OS TURISTAS}

Jeri (como se referem os moradores e frequentadores) foi citada internacionalmente pelo jornal americano The Washington Post, em 15 de março de 1987, numa lista dos dez lugares mais belos do mundo, fato que despertou o aumento considerável de sua procura por turistas (nacionais e estrangeiros). Antes disso, a vila era visitada por um pequeno número de viajantes, em sua maioria hippies e "mochileiros", que buscavam no local a tranqüilidade e um contato íntimo com a natureza, hospedando-se nas casas de pescadores. É possível pressupor que o público àquela época demonstrava um respeito maior à natureza e à cultura local.

A presença deste tipo de turistas (eventuais, aventureiros, solitários) definiu (a ainda define) diversas localidades do planeta como lugares turísticos. Conforme Cruz (2001, p. 21):

\footnotetext{
${ }^{41}$ Jornal Diário do Nordeste. Cidade. Fortaleza, 20 de maio de 2005.
} 
A apropriação primitiva de lugares por turistas pode ou não desdobrar-se em uma apropriação organizada, ou seja, na inserção dessas localidades entre os destinos turísticos oficiais. O modo como se dá a passagem de uma para outra condição é que vai determinar a qualidade $e$ a intensidade das transformações passíveis de ocorrer nesses territórios devido a seu uso pelo turismo.

Jericoacoara insere-se nos casos em que a funcionalização turística do espaço ocorre devido à pressão da demanda, e sua chegada põe em ação os agentes que ofertam serviços, provocando mudanças na produção do espaço (Sánchez, 1991).

O tipo de turista que deu origem à especialização turística de Jericoacoara foi substituído por turistas de classe média / alta, com predominância do sexo masculino, alguns dos quais também buscam diversão e vida noturna, sexo e uso de drogas, uma vez que os mesmos provêem de áreas urbanas e, em muitos casos, de grandes cidades. A casa do pescador já não tem mais tanta importância para estes turistas, uma vez que os mesmos hospedam-se em pousadas, hotéis ou casas alugadas.

Esses turistas esperam, muitas vezes, encontrar, no lugar visitado, algo similar ao que dispõem em seu lugar de residência e, em função disso, são criados na vila, por exemplo, alguns cyber cafés e danceterias. José Osmar Fonteles (2004, p. 86) identificou em Jericoacoara a presença de "turistas ecológicos e não ecológicos, alternativos e de massa, de lazer e mesmo de eventos" $^{\prime 42}$.

A Vila de Jericoacoara é conhecida internacionalmente e boa parte dos turistas estrangeiros chegam através de vôos charters à capital, Fortaleza, que como dissemos anteriormente, é o portão de entrada do turismo no estado do Ceará. De Fortaleza, pode-se chegar à Jericoacoara de ônibus (aproximadamente 7 horas de viagem), avião (desembarcando no aeroporto de Camocim - uma cidade próxima - e seguindo via terrestre até a vila) e há

\footnotetext{
${ }^{42}$ O autor não define, porém, cada um desses segmentos. No que diz respeito a eventos houve, em 1996, a Primeira Regata Verde de Canoas de Jericoacoara, com o intuito de atrair turistas na baixa temporada, promovido pelo Conselho Comunitário.
} 
também passeios off-road, oferecidos por agências de turismo especializadas neste tipo de viagem.

Segundo dados da SETUR, Jericoacoara recebe $14 \%$ do total da demanda de turistas do Estado do Ceará que em 2004, ultrapassou a marca de 1.700.000 turistas. A maioria dos turistas estrangeiros em Jericoacoara são provenientes da Holanda, Itália e Argentina, e os nacionais, provenientes de São Paulo (principal pólo emissor de turistas no Brasil), Rio de Janeiro e Minas Gerais, conforme quadros 7 e 8 :

\begin{tabular}{|l|c|}
\hline \multicolumn{2}{|c|}{ QUADRO 7 } \\
Procedência dos turistas (2005) \\
\hline Países & Geral (\%) \\
\hline Brasil & 66,1 \\
Holanda & 6,2 \\
Itália & 4,1 \\
Argentina & 3,1 \\
Canadá & 2,0 \\
Israel & 2,0 \\
Inglaterra & 1,8 \\
Outros & 14,7 \\
\hline Total & 100,0 \\
\hline
\end{tabular}

Fonte: SETUR - Pesquisa Direta - Fevereiro de 2005

\begin{tabular}{|l|c|}
\hline \multicolumn{2}{|c|}{ QUADRO 8 } \\
Procedência dos turistas nacionais (2005) \\
\hline Estados & Geral (\%) \\
\hline São Paulo & 29,6 \\
Rio de Janeiro & 10,7 \\
Minas Gerais & 10,7 \\
Distrito Federal & 8,5 \\
Ceará & 7,2 \\
Rio Grande do Sul & 5,0 \\
Piauí & 4,4 \\
Bahia & 3,8 \\
Pernambuco & 3,8 \\
Outros & 16,3 \\
\hline Total & 100,00 \\
\hline
\end{tabular}

Fonte: SETUR - Pesquisa Direta - Fevereiro de 2005 
Em entrevista acerca da presença de turistas em Jericoacoara ${ }^{43}$, Marcos Dantas, subsecretário de turismo do Município, afirmou que a vila contou com cerca de 12 mil turistas na passagem do ano de 2005, e essa estimativa pode chegar a 14 mil levando-se em consideração à presença de pessoas que chegam e voltam no mesmo dia ${ }^{44}$. O mesmo afirma que cada turista gasta em média de 250 a 300 reais por dia, e "eles chegam de carro pequeno, de veículo $4 \times 4$, pau-de-arara, ônibus de linha e até de helicóptero, este último, por sinal, quando baixa ao lado da duna é uma correria, gente com filmadoras e câmeras fotográficas cercam a aeronave na expectativa de flagrarem alguma celebridade...".

Cabe ressaltar que alguns turistas transformaram-se em moradores, dado o deslumbramento adquirido pelo lugar enquanto, num primeiro momento, eram apenas visitantes. Assim, alguns tornaram-se donos de pousadas, comerciantes, ou empregados em estabelecimentos diversos na vila, como é o caso de uma jovem paulistana que conseguiu um emprego temporário como garçonete num restaurante local e, desta forma, planejou sua permanência em Jericoacoara para um ano, morando em casa alugada com outras pessoas nestas mesmas condições.

\subsection{OS PLANEJADORES E PROMOTORES TERRITORIAIS E AS POLÍTICAS DE TURISMO}

$\mathrm{O}$ agente Estado, aqui representado pelos planejadores e promotores territoriais, tem uma inestimável hegemonia no processo de produção do espaço da vila de Jericoacoara para o turismo se comparado aos agentes citados anteriormente (habitantes locais, mercado e turistas). Esta diferenciação não ocorre por acaso, mas como reflexo do papel efetivo que tem

\footnotetext{
${ }^{43}$ Jornal Diário do Nordeste. Regional. Fortaleza, 13 de janeiro de 2005.

${ }^{44}$ Lembre-se que a vila de Jericoacoara conta com cerca de 2.328 moradores.
} 
tido o poder público na produção do espaço para o turismo (neste caso, regional, representado pelo nordeste brasileiro).

Com o turismo, espaços antes não-urbanizados (pequenas localidades, como Jericoacoara) começam a viver um intenso e abrupto processo de transformação, decorrente de toda uma infra-estrutura urbana necessária ao fazer turístico e, neste contexto, é lícito dizer que "a lógica do Estado completa a lógica da mercadoria, igualizando as desigualdades [...], impondo estruturas espaciais homogeneizantes, fragmentadoras e hierarquizantes" (Damiani, 2001, p. 51). No que diz respeito ao caráter espacial das intervenções do Estado, a autora afirma que "a planificação espacial tem uma função organizadora na economia, e a economia moderna cada vez mais toma forma espacial: os fluxos se generalizam. E o domínio do espaço tende a torná-los eficientes, tentando anular as contradições" (p. 56).

O estado do Ceará foi e ainda vem sendo (re)configurado territorialmente de forma a atender às demandas do turismo. À respeito do papel do Estado nesta questão, coloca Lima (2002, p.82-83):

Os resultados da intervenção estatal estão espacialmente manifestos na zona costeira cearense: reforma do Aeroporto Internacional Pinto Martins ${ }^{45}$, estradas asfaltadas, rodovias construídas e/ou ampliadas, construção de infra-estrutura de saneamento básico e urbanização turística. Além disso, conferiu-se incentivo aos empreendedores turísticos (recursos financeiros e pouca exigência em termos de mitigação dos impactos ambientais).

\footnotetext{
${ }^{45}$ Localizado na capital, Fortaleza.
} 


\begin{tabular}{|c|c|c|c|c|c|c|c|}
\hline \multicolumn{8}{|c|}{$\begin{array}{c}\text { QUADRO } 9 \\
\text { Metas para os Agregados Turísticos - 1995/2007 }\end{array}$} \\
\hline \multirow[t]{2}{*}{ Agregados } & \multicolumn{2}{|c|}{ Resultados } & \multicolumn{2}{|c|}{$\begin{array}{l}\text { Variações } \\
(\%)\end{array}$} & \multicolumn{2}{|c|}{ Metas } & \multirow[t]{2}{*}{$\begin{array}{l}2007 / 05 \\
\operatorname{Var}(\%)\end{array}$} \\
\hline & 1995 & 2005 & Total & Anual & 2006 & 2007 & \\
\hline Demanda Turística via & & & & & & & \\
\hline Fortaleza & 761.777 & 1.968 .856 & 158,5 & 10,0 & 2.250 .000 & 2.500 .000 & 27,0 \\
\hline - nacional & 723.688 & 1.703 .060 & 135,3 & 8,9 & 1.935 .000 & 2.125 .000 & 24,8 \\
\hline - Internacional & 38.089 & 265.796 & 597,8 & 21,4 & 315.000 & 375.000 & 41,1 \\
\hline $\begin{array}{l}\text { Receita Turística Direta } \\
\text { (R\$ milhões) }\end{array}$ & 4860 & 23004 & 3733 & 168 & 29700 & 34250 & 48.9 \\
\hline Renda Gerada & 651,2 & $4.025,8$ & 518,2 & 20,0 & $5.197,5$ & $5.993,8$ & 48,9 \\
\hline $\begin{array}{l}\text { (R\$ milnoes) } \\
\text { - Impacto sobre o PIB }\end{array}$ & 5,2 & 11,8 & 126,1 & 8,5 & 14,1 & 15,0 & 27,6 \\
\hline Oferta Hoteleira no Ceará & & & & & 26880 & & \\
\hline - Fortaleza & $\begin{array}{r}10.739 \\
5.264\end{array}$ & $\begin{array}{l}22.990 \\
10.407\end{array}$ & $\begin{array}{r}114,1 \\
97,7\end{array}$ & $\begin{array}{l}7,9 \\
7,1\end{array}$ & $\begin{array}{l}20.880 \\
11.200\end{array}$ & 12.000 & $\begin{array}{l}30,5 \\
15,3\end{array}$ \\
\hline - Interior & 5.475 & 12.583 & 129,8 & 8,7 & 15.680 & 18.000 & 43,1 \\
\hline Nível de Emprego no & & & & & & & \\
\hline Turismo do CE (mil) & 122 & 256 & 109,8 & 7,7 & 266 & 272 & 6,1 \\
\hline $\begin{array}{l}\text { - Participação na PEA } \\
(\%)\end{array}$ & 3.8 & 6.7 & 75,3 & 5,8 & 6.8 & 6.8 & 2.0 \\
\hline $\begin{array}{l}\text { Movimento no Aeroporto } \\
\text { (mil Pax) }\end{array}$ & 1.147 & 2.399 & 109,2 & 7,7 & 2.650 & 3.000 & 25,1 \\
\hline Movimentação Turística $\left({ }^{*}\right)$ & 3.275 .641 & 8.309 .097 & 153,7 & 9,8 & 9.675 .000 & 10.750 .000 & 29,4 \\
\hline
\end{tabular}

Nos seus estudos sobre a geografia do turismo na Região Nordeste do Brasil, Cruz (2001) analisa as políticas de turismo incidentes sobre esse território, como a Política de Megaprojetos e o PRODETUR-NE, que tecem efeitos tanto nas capitais dos estados como também sobre pequenas localidades litorâneas e do interior da região.

Em termos gerais, as políticas públicas de turismo devem criar as condições para fomentar a atividade turística no país, através de parcerias e articulação com os diversos agentes, de modo a executar e avaliar programas e projetos voltados para o setor. Conforme Cruz (2001, p. 32), "uma política de turismo pode ser entendida como um conjunto de intenções, diretrizes e estratégias estabelecidas e/ou ações deliberadas, no âmbito do poder público, em virtude do objetivo geral de alcançar e/ou dar continuidade ao pleno desenvolvimento da atividade turística num dado território". Num primeiro momento, uma política pública de turismo é fruto do processo de planejamento governamental para o setor turismo, e em outro momento passa a orientar este processo de planejamento, que assume a forma de projetos, programas, 
planos, entre outros. Em suma, conforme Hall (2004), uma política pública é tudo o que um governo decide fazer ou não.

O PRODETUR-NE (Programa de Desenvolvimento do Turismo no Nordeste), lançado em 1991, é uma "política de urbanização" para o turismo, financiado pelo BID (Banco Interamericano de Desenvolvimento) ${ }^{46}$, que visa à criação de infra-estruturas (essencialmente urbanas) que darão suporte ao turismo, como as de acessibilidade, circulação, saneamento básico, entre outros. Trata-se, portanto, de uma política de turismo que faz as vezes de uma política urbana (Cruz, 2001).

Como marco conceitual das ações de planejamento territorial do turismo no estado do Ceará, o PRODETURIS (Programa de Desenvolvimento do Turismo do Litoral do Ceará) foi um programa criado em 1989, promovido e viabilizado pelo governo estadual, "compreendido como um conjunto de ações e de diretrizes voltadas para um diagnóstico territorial e para o planejamento a longo prazo de territorialidades turísticas" litorâneas (Benevides, 2004, p. 76). Fruto de um contrato celebrado entre o governo estadual e um consórcio de empresas de consultoria, o PRODETURIS foi antecessor da criação do PRODETUR-NE e à sua versão cearense, ou seja, o PRODETUR-CE. Conforme Benevides (2004, p.76), "findo os inventários territoriais, os estudos técnicos, os diagnósticos, os projetos, o relatório de oportunidades de investimentos e o relatório final, todos estes documentos elaborados pelo PRODETURIS acabaram por subsidiar os termos de referência a concepção e os conceitos operativos para a área prioritária inicial do PRODETUR-NE no Ceará ${ }^{47}$.

O PRODETURIS produziu um zoneamento territorial no Ceará que foi seguido pelo PRODETUR-CE. O mesmo consistia em quatro regiões turísticas (RT) em áreas litorâneas e, nas palavras de Benevides (2002, p. 153), "a

\footnotetext{
${ }^{46}$ Nas palavras de Rodrigues (2001, p. 102), “...fecunda é a busca da compreensão da ideologia subjacente que determina as diretrizes políticas, quase sempre elitistas, com tendência a favorecer a classe empresarial, em particular os megaprojetos sustentados por capitais transnacionais, por intermédio dos agentes financeiros mundiais, tipo Banco Mundial, Banco Interamericano de Desenvolvimento, além de outros".

${ }^{47}$ O PRODETURIS teve seu relatório final elaborado em 1990.
} 
região contemplada inicialmente pelo PRODETUR-CE I é a RT II, na qual foram também incluídos os municípios de Caucaia e Fortaleza".

\begin{tabular}{|l|l|}
\hline \multicolumn{3}{|c|}{ QUADRO 10 } \\
\multicolumn{2}{|c|}{ Regiões turísticas definidas pelo PRODETURIS (1990) e seus municípios } \\
\hline RT I - Região Metropolitana & Fortaleza, Aquiraz, Caucaia \\
\hline RT II - Sol Poente I & $\begin{array}{l}\text { São Gonçalo do Amarante, Paracuru, } \\
\text { Paraipaba, Trairi e Itapipoca }\end{array}$ \\
\hline RT III - Costa Sol Nascente & Cascavel, Beberibe, Fortim, Aracati, Icapuí \\
\hline RT IV - Sol Poente II & $\begin{array}{l}\text { Barroquinha, Camocim, Cruz, Acaraú, Itarema, } \\
\text { Jijoca de Jericoacoara, Amontada }\end{array}$ \\
\hline
\end{tabular}

Fonte: Benevides (2002). Org.: Fabio Molina

\begin{tabular}{|c|c|c|}
\hline \multicolumn{3}{|c|}{$\begin{array}{c}\text { QUADRO } 11 \\
\text { Ceará - Macrorregiões Turísticas (Configuração de 2005) }\end{array}$} \\
\hline Macrorregiões Turísticas & $\begin{array}{c}\text { Regiões Turísticas - Áreas } \\
\text { de Governança }\end{array}$ & $\begin{array}{c}\text { Roteiro Turístico - Salão do } \\
\text { Turismo }\end{array}$ \\
\hline Fortaleza / Metropolitana & Fortaleza & Roteiro de Fortaleza (1) \\
\hline \multirow[t]{3}{*}{ Litoral Oeste / Ibiapaba } & Litoral Oeste / Vale do Curu & Roteiro Costa Sol Poente \\
\hline & $\begin{array}{c}\text { Litoral Extremo Oeste } \\
\text { Serra da Ibiapaba }\end{array}$ & Roteiro Serra de lbiapaba \\
\hline & Vale do Acaraú & Roteiro Vale do Acaraú \\
\hline \multirow{2}{*}{$\begin{array}{l}\text { Litoral Leste / Apodi / Vale } \\
\text { do Jaguaribe }\end{array}$} & Litoral Leste & Roteiro Costa Sol Nascente \\
\hline & Vale do Jaguaribe & - \\
\hline Serras Úmidas / Baturité & $\begin{array}{l}\text { Serras de Aratanha e } \\
\text { Baturité }\end{array}$ & $\begin{array}{l}\text { Roteiro das Serras de } \\
\text { Aratanha e Baturité }\end{array}$ \\
\hline Sertão Central & Sertão Central & Roteiro do Sertão Central (2) \\
\hline \multirow{2}{*}{$\begin{array}{l}\text { Araripe / Cariri / Vale do } \\
\text { Salgado }\end{array}$} & Cariri & Roteiro do Cariri (3) \\
\hline & Vale do Salgado & - \\
\hline Sertão dos Inhamuns & Sertão dos Inhamuns & - \\
\hline \multicolumn{3}{|c|}{$\begin{array}{l}\text { 1. Roteiro da Cultura, Compras, Gastronomia, Entretenimento } \\
\text { 2. Roteiro do Vale Monumental / Roteiro Caminhos da Fé } \\
\text { 3. Roteiro Caminhos da Fé / Roteiro Terra dos Kariris }\end{array}$} \\
\hline
\end{tabular}

Fonte: Setur/CE, 2005. 


\section{Ceará - Macrorregiões Turísticas}

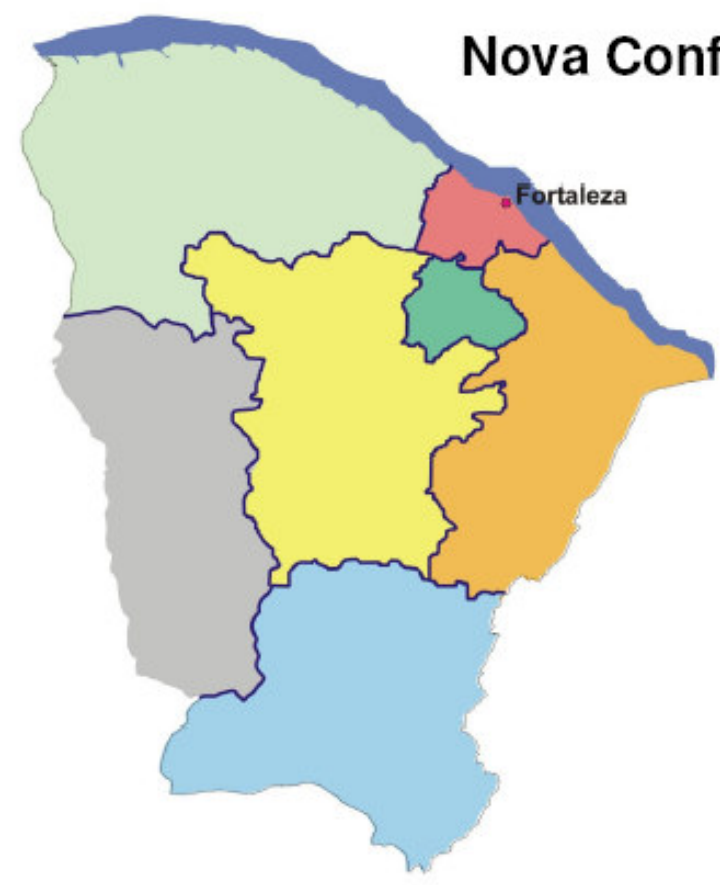

Fig. 15 - Macrorregiões turísticas do Ceará Fonte: SETUR/CE, 2005

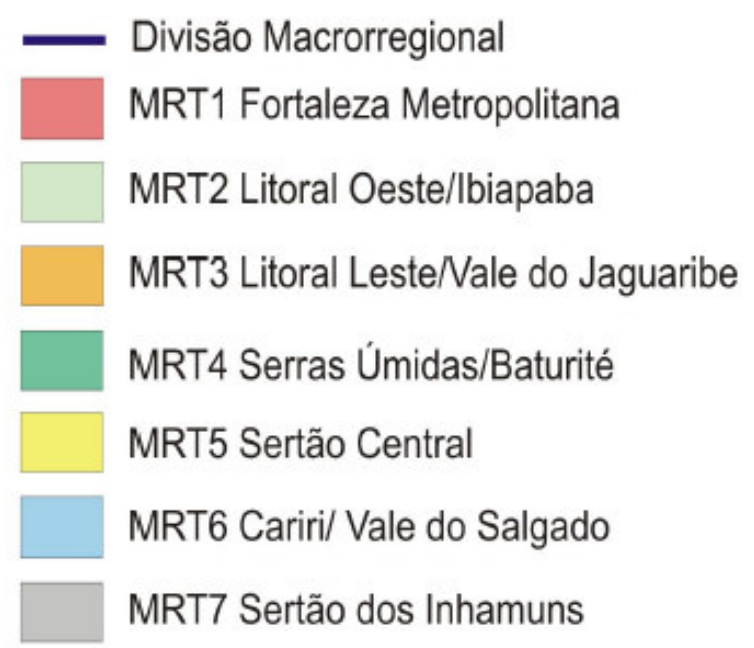

O PRODETUR-CE é, em suma, um desdobramento do PRODETURIS, seguindo ainda as orientações do PRODETUR-NE, que é um programa ao nível federal que se dá nos nove estados nordestinos, fruto de uma contrato entre o governo federal e o BID (Banco Interamericano de Desenvolvimento), que entra com 50\% dos recursos (em alguns casos, 60\%). Há, ainda, a exigência de uma contrapartida estadual antes que o BID libere os recursos, juntamente com o governo federal (este último forneceu empréstimos a alguns estados nordestinos que não tinham como arcar sozinhos com os recursos da exigida contrapartida estadual).

Conforme a SETUR-CE (2002, [p.2]), o PRODETUR-NE "foi concebido a partir de gestões dos Governadores do Nordeste, junto ao Banco do Nordeste S/A (BN), Superintendência do Desenvolvimento do Nordeste (SUDENE), Instituto Brasileiro de Turismo (EMBRATUR) e Comissão de Turismo Integrado do Nordeste (CTI/NE)". Além disso, o programa tem como agentes financeiros o BID e o BNDES (Banco Nacional de Desenvolvimento Econômico e Social), sendo o Banco no Nordeste o órgão mutuário e executor. 
No território cearense, a Secretaria do Turismo do Estado - SETUR atua como órgão coordenador e executor estadual e dentre os órgãos estaduais envolvidos tem-se a SEINFRA (Secretaria de Infra-Estrutura), CAGECE (Companhia de Água e Esgoto do Ceará), DERT (Departamento de Edificações, Rodovias e Transportes), SOMA (Secretaria da Ouvidoria Geral e do Meio Ambiente), SECULT (Secretaria da Cultura) e a SEMACE (Secretaria do Meio Ambiente do Ceará). Segundo a SETUR (2002, p. [2]):

\begin{abstract}
O PRODETUR-CE I é um programa principalmente de obras múltiplas, cujo cenário é definido pelos instrumentos de orientação e parceria dos investimentos da iniciativa pública Estado e Prefeituras - e da iniciativa privada. O Governo é o indutor com ações de infra-estrutura básica, fortalecimento institucional e meio ambiente. A iniciativa privada é o agente interventor dos projetos de serviços e equipamentos turísticos e de atividades produtivas que asseguram o desenvolvimento econômico da região.
\end{abstract}

No que diz respeito à relação Estado - turismo, destaca-se um discurso segundo o qual o turismo gera emprego, renda, desenvolvimento, presente também no objetivo básico do PRODETUR-CE I, que é o de promover "... o desenvolvimento econômico do Estado, elevando o nível de emprego e renda da população a partir da organização da infra-estrutura possibilitando o fomento aos investimentos na indústria do turismo, na agroindústria e no setor de serviços" (SETUR, 2002, p. [2]).

Disso decorre, segundo Cruz (2001, p. 31) "a criação (forjada) de um senso comum de que o turismo constitui a saída econômica para o Nordeste, ou seja, uma possibilidade concreta de minimização das disparidades regionais existentes entre esta a as regiões mais desenvolvidas do país". Antes de mais nada, e ainda conforme a autora, tem-se que ter em mente que o turismo representa apenas uma pequena parte de um imenso jogo de relações e, portanto, não cabe somente a ele a responsabilidade de promover a tão sonhada justiça e igualdade social. Uma vez que esta discussão não é o foco de nossas análises neste trabalho e portanto não será melhor aprofundada, ressalte-se apenas que o turismo, como reflexo do modo capitalista de produção, é uma atividade que busca, entre tantas outras coisas, o lucro, e 
leva, tanto quanto outras atividades econômicas, à concentração de riquezas nas mãos de poucos. A este respeito, Benevides (2004, p. 286) afirma:

Inserido num padrão de desenvolvimento concentrador e articulado a uma ordem exógena orientando as organizações de seus territórios, o planejamento do turismo é uma estratégia territorial integrante da reprodução desse padrão e da periferização seletiva de novos lugares turísticos. O turismo é o novo espaço que cabe ao Ceará e ao Nordeste, principalmente, litorâneos, para inserirem-se rutilantemente na nova divisão territorial e social do trabalho nas escalas nacional e internacional. No máximo é um "setor" relevante no Nordeste, contudo, imerso na complexa tessitura das relações que estruturam e comandam um amplo processo de (sub)desenvolvimento sócio-econômico regional.

Os recursos da primeira etapa do programa (PRODETUR I) totalizaram, segundo a SETUR-CE (2002, [p.2]), "inicialmente US\$ 166,13 milhões para obras de estradas, construção do Aeroporto Internacional Pinto Martins de Fortaleza e sua via de acesso, sistemas de abastecimento d'água e esgotamento sanitário, meio ambiente e proteção ambiental e fortalecimento institucional dos Órgãos Estaduais e Municipais envolvidos no Programa".

\begin{tabular}{|c|c|c|}
\hline \multicolumn{3}{|c|}{$\begin{array}{c}\text { QUADRO } 12 \\
\text { Distribuição dos Investimentos e Participações na Fase I do PRODETUR- } \\
\text { CE }\end{array}$} \\
\hline PROJETOS & US\$ Milhões & $\%$ \\
\hline Rodovias & 24,59 & 15,36 \\
\hline Aeroporto & 78,20 & 48,87 \\
\hline Saneamento Básico & 36,82 & 23,00 \\
\hline Meio Ambiente & 5,39 & 3,37 \\
\hline Desenvolvimento Institucional & 2,68 & 1,68 \\
\hline Custos de Operação & 5,33 & 3,33 \\
\hline Engenharia e Administração & 7,03 & 4,39 \\
\hline
\end{tabular}

Fonte: SETUR/CE (2004)

Estas ações abarcaram uma extensão de $155 \mathrm{~km}$ de litoral a oeste de Fortaleza (parte do Pólo Ceará Costa do Sol), contemplando 7 sedes municipais (Fortaleza, Caucaia, São Gonçalo do Amarante, Paracuru, Paraipaba, Trairi e Itapipoca) e, nestas, 21 localidades costeiras. O Pólo Ceará 
Costa do Sol, em sua totalidade, abrange os seguintes 18 municípios: Aquiraz, Fortaleza, Caucaia, São Gonçalo do Amarante, Paracuru, Paraipaba, Trairi, Itapipoca, Amontada, Itarema, Acaraú, Cruz, Jijoca de Jericoacoara, Camocim, Barroquinha, Chaval, Granja e Viçosa do Ceará.

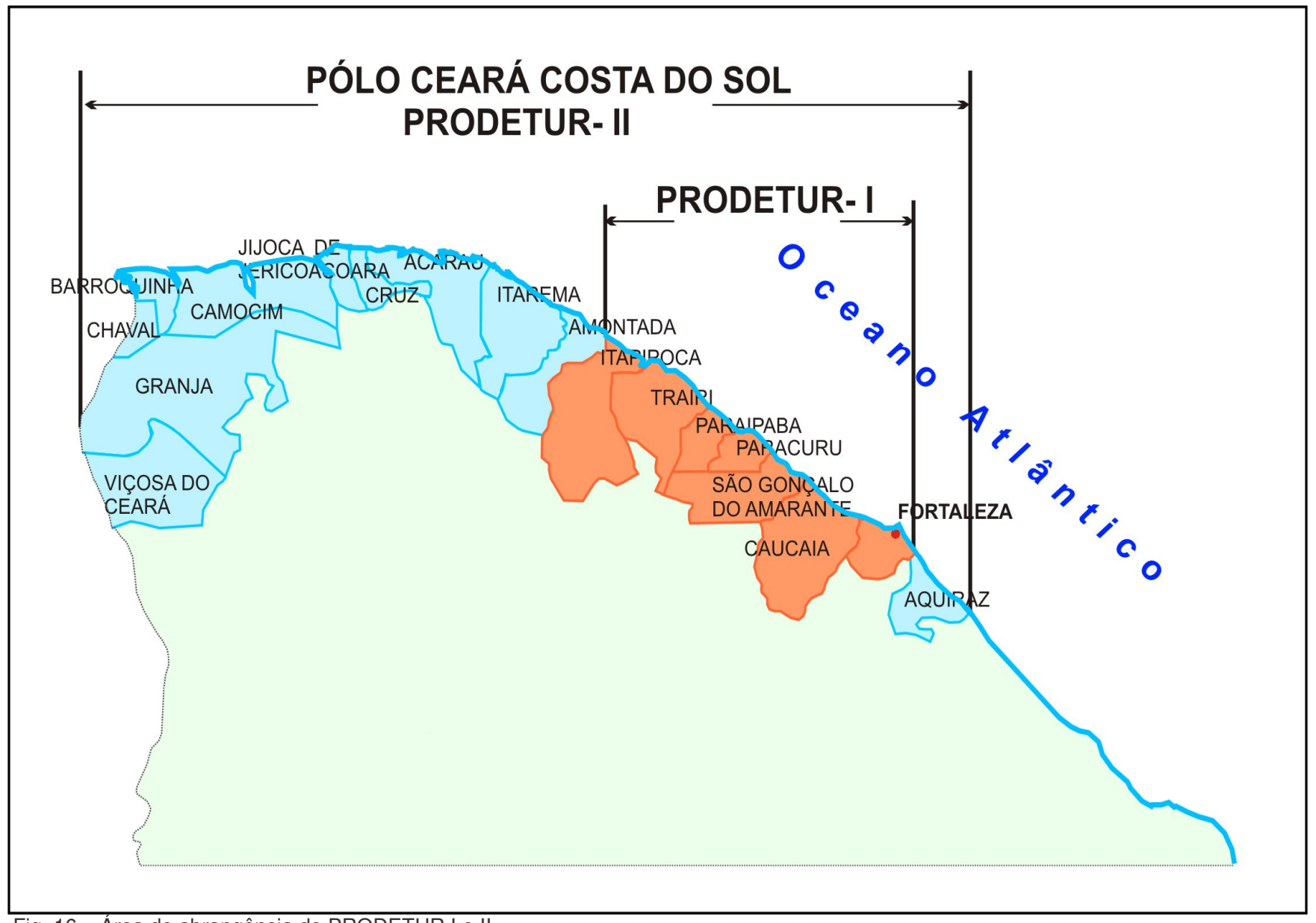

Fig. 16 - Área de abrangência do PRODETUR I e II

Fonte: SETUR-CE, 2005

A respeito da criação de condições materiais e imateriais ao desenvolvimento do turismo no Ceará (iniciado com o PRODETUR-CE), Ireleno Porto Benevides (2004, p. 161-162) elucida três componentes na questão de planejamento turístico: o componente da infra-estrutura básica - que contempla a materialização, no espaço, de um novo sistema de engenharia (sistema viário, de saneamento, energético e de proteção ambiental); o componente da infra-estrutura de apoio, que visa a articulação dos poderes estadual e municipal através do apoio à capacitação dos núcleos urbanos e as áreas de 
uso turístico (com o aprimoramento de serviços e equipamentos urbanos, e capacitação da população local) e ainda o componente institucional, que diz respeito à criação de instrumentos técnico-normativos, que se traduzem também no fortalecimento das prefeituras para a gestão, o acompanhamento e o controle do PRODETUR em nível local, conforme está contemplado para a fase II do programa.

O Programa encontra-se atualmente em sua segunda etapa (PRODETUR II), submetido ainda à aprovação do Banco do Nordeste ${ }^{48}$, através da análise do PDITS (Plano de Desenvolvimento Integrado do Turismo Sustentável), que se trata basicamente de um plano elaborado com a finalidade de avaliar e efetuar o diagnóstico turístico das áreas abrangidas pelo PRODETUR I e apontar as ações para o PRODETUR II que inclui, no Ceará, todos os municípios do Litoral Oeste e também o município de Aquiraz.

O objetivo da segunda etapa do PRODETUR/NE repete o discurso já utilizado anteriormente: a melhoria da qualidade de vida de populações locais a partir do desenvolvimento sustentável do turismo. Conforme texto presente no Parecer Técnico do PDITS Ceará Costa do Sol (2004, p.1-2),

As Condições Gerais do Regulamento Operacional do PRODETUR/NE-II (ROP) dispõem que a inserção dos Estados e Municípios no Programa tem como base uma política de turismo, focada no conceito de pólos de turismo e detalhada sob a forma de um Plano de Desenvolvimento Integrado do Turismo Sustentável - PDITS, que por sua vez deve ser validado pelo Conselho de Turismo do Pólo.

O PDITS foi elaborado no ano de 2003 por uma empresa de consultoria turística localizada na cidade de São Paulo, a Ruschmann Consultores, juntamente com o Governo do Estado do Ceará $^{49}$ (diga-se de passagem, uma empresa hegemônica no que diz respeito à elaboração de planos e projetos de desenvolvimento do turismo no país). Conforme texto do Plano (2003), "o PDITS nasceu para estabelecer todas as diretrizes, normas, procedimentos,

\footnotetext{
${ }^{48}$ O PRODETUR II tem como mutuário do programa o Banco do Nordeste (BN), e como coordenador e executor estadual a Secretaria de Turismo do Estado do Ceará (SETUR-CE).

${ }^{49}$ O Governo do Estado do Ceará utiliza o PDITS como um instrumento para a operacionalização das ações para o turismo. Além disso, o PDITS apresenta-se como um requisito para o PRODETUR II.
} 
áreas de investimentos públicos e privados, metas, indicadores e todas as condições para se ampliar os negócios turísticos em toda a região entre Aquiraz e Jijoca de Jericoacoara". Abaixo, segue quadro de análise SWOT ${ }^{50}$ presente no PDITS referente à Jijoca de Jericoacoara e Camocim, municípios tratados juntamente, provavelmente devido à proximidade territorial, apesar de apresentarem, in loco, realidades, existências, situações geográficas ${ }^{51}$ distintas:

\begin{tabular}{|c|c|c|}
\hline \multicolumn{3}{|c|}{$\begin{array}{c}\text { QUADRO 13 } \\
\text { Análise SWOT das áreas de interesse turístico: Jijoca de Jericoacoara e } \\
\text { Camocim (2003) }\end{array}$} \\
\hline & $\begin{array}{l}\text { POTENCIALIDADES } \\
\text { - Receptividade ao turista } \\
\text { - Parque Nacional de } \\
\text { Jericoacoara } \\
\text { - Peculiaridade da vila de } \\
\text { Jericoacoara } \\
\text { - Grandes áreas com baixa } \\
\text { ocupação } \\
\text { - Patrimônio natural de grande } \\
\text { expressão }\end{array}$ & $\begin{array}{l}\frac{\text { FRAQUEZAS }}{\text { - Insuficiência dos serviços de }} \\
\text { saneamento básico } \\
\text { - Impactos ambientais de } \\
\text { média gravidade, } \\
\text { principalmente nas dunas, } \\
\text { lagoas e lagamares }\end{array}$ \\
\hline $\begin{array}{l}\text { OPORTUNIDADES } \\
\text { - Existência de recursos } \\
\text { públicos para investimentos } \\
\text { em turismo } \\
\text { - Migração de parte do fluxo } \\
\text { turístico de Fortaleza e } \\
\text { municípios limítrofes } \\
\text { - Desenvolvimento turístico da } \\
\text { Área de Planejamento Costa } \\
\text { do Delta - PI }\end{array}$ & $\begin{array}{l}\text { a) Incentivar a instalação de } \\
\text { empresas de turismo voltadas } \\
\text { ao segmento de lazer e } \\
\text { ecoturismo } \\
\text { b) Dar continuidade às } \\
\text { campanhas de marketing que } \\
\text { vêm sendo desenvolvidas } \\
\text { atualmente } \\
\text { c) Posicionar a região como } \\
\text { destino ecoturístico }\end{array}$ & $\begin{array}{l}\text { e) Investir na ampliação do } \\
\text { sistema de saneamento } \\
\text { básico dos municípios } \\
\text { f) Desenvolver ações } \\
\text { mitigadoras visando evitar } \\
\text { possíveis impactos }\end{array}$ \\
\hline $\begin{array}{l}\text { RISCOS } \\
\text { - Crescimento desordenado } \\
\text { das cidades e da atividade } \\
\text { turística }\end{array}$ & $\begin{array}{l}\text { d) Ordenar o uso turístico e a } \\
\text { ocupação das praias e } \\
\text { atrativos naturais }\end{array}$ & $\begin{array}{l}\text { g) Evitar a implantação de } \\
\text { novos empreendimentos em } \\
\text { áreas ainda desprovidas de } \\
\text { infra-estrutura }\end{array}$ \\
\hline
\end{tabular}

Fonte: PDITS - Ruschmann Consultores (2003)

50 A sigla SWOT significa "Strengths, Weaknesses, Opportunities, Threats" (ou Forças, Fraquezas, Oportunidades e Ameaças) e trata-se de uma análise voltada ao diagnostico e definições de planos estratégicos de ação. Originariamente utilizado na área de administração de empresas, o método de análise SWOT vem sendo utilizado em planejamento estratégico do turismo. O Relatório Técnico do PDITS (2004, p.18) apresentou uma crítica à utilização deste método: "ainda que propostos na formulação das estratégias, os resultados advindos do cruzamento dos fatores mencionados na aplicação da Matriz SWOT não são utilizados adequadamente, não se constatando os vínculos entre diagnóstico e estratégias. As chamadas macroestratégias se resumem à descrição dos componentes do PRODETUR/NE II".

51 A idéia de situação geográfica é, para Silveira (1999b, p. 22), vinculada à noção de evento, compreendido como um veículo de possibilidades existentes no mundo e que se geografizam no lugar. Numa situação geográfica podemos reconhecer "objetos técnicos, ações, normas, agentes, escalas, ideologias, discursos, imagens, que são diversos no processo histórico e nos lugares” (p. 26). 
Tendo em vista o desenvolvimento do PDITS no estado do Ceará ${ }^{52}$, reuniões foram realizadas com a participação das comunidades, instituições públicas e privadas, prefeituras e ONGs, no intuito de se validar o diagnóstico turístico e os projetos propostos para a área de planejamento do Pólo Ceará Costa do Sol. A dinâmica destas reuniões deu-se inicialmente com a apresentação do diagnóstico turístico do pólo e proposições dos projetos (Fase I), seguido de 4 grupos de discussões com cerca de 5 representantes (Fase II) organizados da seguinte forma:

\begin{tabular}{|c|c|c|}
\hline \multicolumn{3}{|c|}{$\begin{array}{c}\text { QUADRO } 14 \\
\text { Organização dos grupos de discussões no processo de elaboração do } \\
\text { PDITS }\end{array}$} \\
\hline GRUPOS & TEMAS & SUB-COMPONENTES \\
\hline 1 & Recursos naturais e culturais & $\begin{array}{l}\text { - Proteção e conservação de } \\
\text { recursos naturais } \\
\text { - Proteção e conservação do } \\
\text { patrimônio cultural }\end{array}$ \\
\hline 2 & Infra-estrutura básica & \begin{tabular}{|l|} 
- Gestão de resíduos sólidos \\
- Obras de infra-estrutura \\
- Água potável e saneamento
\end{tabular} \\
\hline 3 & $\begin{array}{l}\text { Serviços receptivos, } \\
\text { capacitação e treinamento }\end{array}$ & $\begin{array}{l}\text { - Campanhas de } \\
\text { conscientização } \\
\text { - Treinamento profissional } \\
\text { - Capacitação da população } \\
\text { local }\end{array}$ \\
\hline 4 & Gestão pública do turismo & $\begin{array}{l}\text { - Gestão administrativa e fiscal } \\
\text { dos municípios } \\
\text { - Gestão municipal do turismo } \\
\text { - Planejamento estratégico e } \\
\text { preparação de projetos }\end{array}$ \\
\hline
\end{tabular}

Fonte: PDITS - Ruschmann Consultores (2003)

Org.: Fábio Silveira Molina

Após as reuniões dos grupos acima detalhados, fez-se a apresentação de suas proposições (Fase III), onde as mesmas foram discutidas (Fase IV) para, por fim, serem incorporadas ao PDITS (Fase V). Pela relevância das informações contidas em tabela presente no PDITS, segue abaixo (quadro 15) observações acerca da drenagem e urbanização da orla da praia de Jericoacoara:

52 Os PDITSs também foram elaborados em outros estados nordestinos que receberam recursos do PRODETUR/NE e que têm a intenção de obter recursos da segunda fase do programa. 


\begin{tabular}{|c|c|}
\hline \multicolumn{2}{|c|}{ Observações acerca da drenagem e urbanização da orla da praia de } \\
Jericoacoara
\end{tabular}

Fonte: PDITS - Ruschmann Consultores (2003)

(com base em vistoria no local em abril de 2002)

Org.: Fábio Silveira Molina

Logo após a finalização do PDITS (setembro de 2003), um Grupo Técnico foi constituído para fins de análise do Plano, no período compreendido entre outubro de 2003 e março de 2004, resultando no Parecer Técnico ${ }^{53}$ e no Relatório Técnico do Plano de Desenvolvimento Integrado do Turismo Sustentável do Pólo Ceará Costa do Sol (o Relatório Técnico apresenta-se como um anexo do Parecer Técnico).

A análise do referido Grupo Técnico, formado por representantes do Ministério do Turismo (MTur), do Banco do Nordeste do Brasil (BNB) e com o apoio de uma consultoria especializada nos diversos aspectos abordados no

${ }^{53}$ Conforme o Parecer Técnico, a análise que dá base ao mesmo teve como instrumento orientador o Termo de Referência (TR), para elaboração dos PDITS, Anexo A do Regulamento Operacional do PRODETUR/NE-II. 
Plano (a Ruschmann Consultores), compreendeu as seguintes atividades: apresentação do PDITS pela Equipe da Unidade Executora Estadual do Programa no Estado do Ceará, UEE/CE, em 23/10/2003; leitura crítica do Plano pelo GT-PDITS; visita às localidades selecionadas entre os municípios do Pólo de 15 a 19/12/2003; e discussão e consolidação do Parecer Técnico.

No Relatório Técnico, que contém uma avaliação dos capítulos do Plano, foram definidas algumas críticas e orientações para efetuação de ajustes no PDITS (o fomento previsto pelo PRODETUR/NE II está condicionado na medida em que estes ajustes são feitos; portanto, em primeira instância, o PDITS não foi aprovado pelo Banco do Nordeste). A essência das críticas diz respeito à presença de análises superficiais de impactos (sociais, econômicos e ambientais) dos locais verificados in loco pelos elaboradores do PDITS, desconsiderando-se ainda as externalidades (à atividade turística e/ou à área de planejamento) que possam interferir na dinâmica local. Desta forma, não há, portanto, uma base sólida para construir e implementar um Plano de Ação à área de planejamento. Entre as observações do Grupo Técnico relacionadas direta ou indiretamente à Jericoacoara, destacam-se (conforme o Relatório Técnico, de janeiro de 2004):

- "A inclusão dos municípios de Jijoca de Jericoacoara e Aquiraz na àrea de planejamento justifica-se devido à identificação da necessidade de implementação de ações locais, voltadas à sustentabilidade da atividade turística nesses municípios";

- "A análise das características do Pólo está estruturada em duas vertentes básicas, compreendendo respectivamente, o conjunto dos municípios de Fortaleza, Caucaia, São Gonçalo do Amarante, Paracuru, Paraipaba, Trairi, Itapipoca que receberam investimentos diretos do PRODETUR/NE I e o conjunto dos municípios de Aquiraz, Jericoacoara e Camocim, considerados impactados pelo primeiro Programa. Esse mecanismo de análise adotado imprimiu dirigismo 
para os municípios que não receberam investimentos do PRODETUR/NE I";

- "Reavaliar, na condução das análises que permeiam todos os capítulos do PDITS, a tendência em se tratar distintivamente os municípios Aquiraz, Jijoca de Jericoacoara e Camocim dos demais municípios da Área de Planejamento que não foram objeto de intervenções do Programa, evitando assim um dirigismo analítico constatado no documento. Esse tipo de análise leva a resultados que nem sempre reproduzem a dinâmica socioambiental da Área de Planejamento, com seus vetores de expansão, podendo distorcer 0 Plano de Ação";

- "Devem ser avaliados os impactos associados a outras ações realizadas pelo PRODETUR/NE I no Pólo. Nesse contexto, deve-se analisar, de forma mais detalhada, os impactos decorrentes do Programa nos municípios de Aquiraz, Jijoca de Jericoacoara e Camocim, cuja inserção na Área de Planejamento é apresentada no PDITS pelo fato de terem sofrido impactos indiretos do PRODETUR/NE I";

- "Os municípios de Jijoca de Jericoacoara e Aquiraz constituem destinos turísticos consolidados, como atestam diversos indicadores que constam do PDITS, apresentando nos últimos anos aumento no fluxo turístico, na capacidade hoteleira, tendo recebido ainda outros investimentos que contribuíram para o desenvolvimento do setor de turismo nesses locais";

- "Constata-se, ainda, que esses municípios [Jijoca de Jericoacoara e Aquiraz] apresentam uma dinâmica de desenvolvimento da atividade turística própria e relativamente independente dos demais municípios da Área de Planejamento. Portanto, não é possível atribuir aos investimentos realizados no âmbito do PRODETUR/NE I todos os impactos, negativos e positivos, do turismo nesses municípios”. 
Ainda no Relatório Técnico do PDITS (2004, p. 35), algumas considerações gerais foram elaboradas sobre Jericoacoara quando o Grupo Técnico do PDITS esteve em visita técnica no local, em dezembro de 2003:

- Passeios de buggys e carros 4x4 são extremamente estimulados, formando enorme marcas de trilhas que vem sendo desenvolvidas possível de ser observada em imagem satélite existente no escritório do IBAMA;

- O Parque Nacional ainda não possui decreto ${ }^{54}$;

- A área do parque vem sofrendo invasões de terras;

- A equipe responsável pela fiscalização da área de parque é subdimensionada.

A Área de Planejamento referente ao PRODETUR/NE II do Ceará, abordada no PDITS, compreende basicamente duas situações: a primeira delas refere-se aos municípios que receberam recursos e sofreram intervenções diretas do PRODETUR/NE I. Neste caso, as ações do PRODETUR/NE II serão a completar e complementar a primeira fase do programa, sob a intenção de garantir a sustentabilidade do turismo. A segunda situação refere-se aos municípios que foram impactados indiretamente pela primeira fase do Programa e Jericoacoara enquadra-se, portanto, nesta situação, juntamente com Camocim ${ }^{55}$ e Aquiraz.

O PRODETUR II é basicamente um programa que deverá complementar e corrigir eventuais falhas da sua primeira fase (PRODETUR I), verificadas in loco pelo PDITS, e apresenta um forte discurso enfocando ora a

\footnotetext{
${ }^{54}$ Observação equivocada, pois o Parque Nacional de Jericoacoara foi criado pelo Decreto Federal n. 9492, de 4 de fevereiro de 2002.

55 Conforme o Relatório Técnico, é insatisfatória a justificativa da inserção de Camocim na Área de Planejamento, pelo fato do mesmo não ser um município em fase de consolidação da atividade turística e, desta forma, sem ter, portanto, um impacto indireto da ação do PRODETUR /NE I no Ceará.
} 
sustentabilidade socioambiental, ora a melhoria na infra-estrutura (principalmente as de acessibilidade) como premissas básicas, de forma a alcançar os dois objetivos principais do programa: a sustentabilidade do turismo no Pólo Ceará Costa do Sol (e com isso afirma-se contribuir para a melhoria da qualidade de vida nos municípios beneficiados pelo Programa, disseminando-se a idéia equivocada de que o turismo minimizará as disparidades sociais no Ceará) e a melhoria na capacidade de gestão do turismo dos governos municipais (através do fortalecimento institucional e da capacitação destes, e de comunidades receptoras, na gestão do turismo em nível local). Como já citado anteriormente, outro aspecto do PRODETUR II (e evidenciado no PDITS) é o tratamento especial às áreas consideradas impactadas pelo PRODETUR I (é aqui que Jericoacoara insere-se na Área de Planejamento do PRODETUR II). Existe ainda, como componente estratégico, a promoção de investimentos do setor privado (integração entre os setores público e privado).

Em termos gerais, o PRODETUR I teve destaque, no Ceará, principalmente pela construção da rodovia Costa do Sol Poente (que visa o acesso a algumas praias do Litoral Oeste) e obras de saneamento e requalificação urbana em alguns municípios de interesse turístico.

A Rodovia Costa do Sol Poente, mesmo não tendo alcançado o município de Jijoca de Jericoacoara, facilitou o deslocamento mais rápido até o mesmo e, desta forma, teve algum impacto sobre o local. Conforme depoimento de Roberto Meira Barreto ${ }^{56}$,

O PRODETUR II irá contemplar algumas obras de infraestrutura ainda absolutamente necessárias para dar o salto de qualidade que o turismo precisa. Cito o Centro Multifuncional de Feiras, o Aeroporto em Parazinho (distrito de Granja, entre este e Jijoca de Jericoacoara) e algumas outras obras estruturantes. Mas a grande vertente do PRODETUR II, complemento do PRODETUR I, será a capacitação nos municípios impactantes, a restauração e a conservação do nosso patrimônio histórico e cultural, o término das obras de saneamento e de preservação do meio ambiente [...] precisamos dar uma arrumada na cidade de Fortaleza que é o

\footnotetext{
${ }^{56}$ Titular da Setur, em entrevista ao jornal Diário do Nordeste no dia 08 de junho de 2003.
} 
grande portão de entrada e começar a trabalhar a qualificação de algumas âncoras como Jericoacoara e Canoa Quebrada.

O total de recursos do PRODETUR II para o nordeste brasileiro é de US $\$ 800$ milhões, divididos em duas etapas, conforme quadro 16 . Indicado no PDITS, o total de recursos do Programa pleiteado pelo estado do Ceará para a primeira etapa do PRODETUR/NE II (US\$400 milhões, disponibilizados desde 2002 ) é de US $\$ 130,56$ milhões (quadro 14). Do total previsto, US $\$ 78,3$ milhões $(60 \%)$ seriam financiados pelo Banco Interamericano de Desenvolvimento (BID), enquanto US $\$ 52,2$ milhões (40\%) formariam a contrapartida dos governos federal e estadual (o empréstimo do BID tem carência de cinco anos e será pago em até 25 anos, com taxa de juros de cerca de $5 \%$ ao ano, sofrendo pequenas variações).

No segundo semestre de 2005, dois contratos de financiamento foram fechados entre o Governo Federal, Governo do Estado de Ceará e o Banco do Nordeste (responsável pela execução do Programa): um primeiro no valor de US\$ 47,3 milhões para obras de infra-estrutura (Rodovia Estruturante, projetos de saneamento básico dos municípios por onde passa a Rodovia, como Fleixeiras, Lagoinha, Caucaia e Jijoca de Jericoacoara e elaboração dos planos diretores dos municípios) e outro no valor de US\$38 milhões, voltados para a urbanização de orlas de alguns municípios (entre eles, Fortaleza) e recuperação do patrimônio histórico do Estado.

\begin{tabular}{|c|c|c|}
\hline \multicolumn{3}{|c|}{$\begin{array}{c}\text { QUADRO } 16 \\
\text { Financiamento do PRODETUR II para o Nordeste } \\
\text { (em milhões de dólares - US\$) }\end{array}$} \\
\hline & $1^{a}$ etapa & $2^{\mathrm{a}}$ etapa \\
\hline BID & 240 & 240 \\
\hline Estado/União & 160 & 160 \\
\hline TOTAL & 400 & 400 \\
\hline
\end{tabular}

Fonte: Setur/CE 


\begin{tabular}{|c|l|r|}
\hline \multicolumn{3}{|c|}{ Quadro 17 } \\
\hline \multicolumn{3}{|c|}{ Projetos e recursos indicados pelo PDITS para o PRODETUR/CE II } \\
\hline № & \multicolumn{1}{|c|}{ Componentes/Projetos } & Valor (milhões de US\$) \\
\hline 1 & $\begin{array}{l}\text { Fortalecimento da capacidade municipal para a } \\
\text { gestão do turismo }\end{array}$ & $35.328 .966,00$ \\
\hline 1.1 & Gestão administrativa e fiscal dos municípios & $70.000,00$ \\
\hline 1.2 & Gestão municipal do turismo & $534.000,00$ \\
\hline 1.3 & Gestão dos resíduos sólidos & $2.200 .000,00$ \\
\hline 1.4 & Proteção e conservação de recursos naturais & $7.267 .000,00$ \\
\hline 1.5 & Proteção e conservação de recursos culturais & $14.067 .966,00$ \\
\hline 1.6 & Urbanização de áreas turísticas & $11.190 .000,00$ \\
\hline 2 & $\begin{array}{l}\text { Planejamento estratégico, treinamento e infra- } \\
\text { estrutura para o crescimento turístico }\end{array}$ & $88.617 .688,00$ \\
\hline 2.1 & $\begin{array}{l}\text { Planejamento estratégico e preparação de } \\
\text { projetos }\end{array}$ & $2.805 .000,00$ \\
\hline 2.2 & Campanhas de conscientização & $600.000,00$ \\
\hline 2.3 & $\begin{array}{l}\text { Treinamento profissional e capacitação da } \\
\text { população local }\end{array}$ & $4.400 .000,00$ \\
\hline 2.4 & Água potável e saneamento & $25.607 .355,00$ \\
\hline 2.5 & Obras de infra-estrutura & $55.205 .333,00$ \\
\hline 3 & Promoção de investimentos do setor privado & $6.613 .365,00$ \\
\hline \multicolumn{2}{|c|}{ TOTAL } \\
\hline
\end{tabular}

Fonte: Setur/CE

As obras de infra-estrutura correspondem àquelas que mais consomem recursos e estas dizem respeito basicamente à construção ou ampliação de vias de circulação (vias estruturantes, de acessos e de percursos) e aeroportos. Seguem-se a estas, em termos de maior montante de recursos necessários, as obras relativas à abastecimento de água e coleta e tratamento de esgotos. Estas obras de engenharia, por sua vez, são, por um lado, requerentes de grandes montantes de recursos; por outro lado, faz-se necessário reconhecer que deficiências em termos de infra-estrutura de saneamento são comuns a todas as regiões do país. 


\section{JERICOACOARA - DAS CONTRADIÇÕES GERAIS À PRODUÇÃO DO ESPAÇO LOCAL}

Com o crescimento acelerado do turismo em Jericoacoara nos últimos anos, a vila passou por significativas transformações espaciais, compreendendo tanto as dimensões sociais como as manifestadamente físicas. Estradas de acesso foram construídas, e há um projeto para a criação de um aeroporto nas proximidades, além de também ter ocorrido a ampliação da infra-estrutura urbana, por exemplo, rede de abastecimento de água e de energia (com fiação subterrânea e ausência de postes de luz nas ruas, por exigência da comunidade local). As mudanças mais significativas estão relacionadas à construção de hotéis, pousadas, restaurantes e outras infraestruturas necessárias para receber os turistas. Como já dissemos anteriormente, houve, também, um processo de ocupação desordenada nos limites da vila com o Parque Nacional de Jericoacoara e a inserção de novas relações de trabalho no local, intensificadas com o incremento da atividade turística, que impulsionou a circulação tanto de pessoas e mercadorias quanto de idéias, valores e informações. Isto não é, a priori, bom ou ruim, mas sabe-se que, de um modo geral, o turismo se impõe aos lugares como uma verticalidade desestabilizadora de uma ordem pré-existente.

As produção espacial em Jericoacoara em função do uso turístico está diretamente relacionada com os interesses privados e a especulação imobiliária, e também com o fato de que:

...o crescimento do capitalismo acaba exigindo uma economia política do e no espaço, caracterizada pela produção do espaço [aliada à questão sobre a qual] as relações de produção capitalistas dominam o espaço e se apropriam dele, passando a produzi-lo e a transforma-lo através do sentido do urbano (SANTANA, Paola Verri, 2001, p. 182).

$\mathrm{Na}$ década de 1990, o Governo do Estado do Ceará (através da Secretaria de Desenvolvimento Local e Regional - SDLR) instituiu, sob o lema 
"urbanizar para desenvolver", o Projeto de Desenvolvimento Urbano e Gestão de Recursos Hídricos (PROURB), também conhecido como Projeto Cidades do Ceará. Trata-se de uma política urbana com a duração de 9 anos (1995 a 2003), em parceria com Prefeituras Municipais e o apoio do Banco Mundial (BIRD), compreendendo um conjunto de 44 municípios, que devem ser estruturados do ponto de vista urbano, tornando-os competitivos para atrair indústrias, impulsionar a agricultra irrigada e incrementar o turismo.

Neste contexto, os municípios do PROURB (no qual Jijoca de Jericoacoara está inserido) elaboraram seus Planos Diretores de Desenvolvimento Urbano (PDDU) de acordo com a política urbana definida na Constituição Federal de 1988, tomados como sendo o principal instrumento de planejamento urbano, composto dos seguintes segmentos: a) caracterização do município, b) planejamento estratégico, c) plano de estruturação urbana, d) legislação e e) projetos estruturantes.

No ano de 1999 foi elaborado o PDDU de Jijoca de Jericoacoara e, entre os principais projetos estruturantes contidos no mesmo ${ }^{57}$ destaca-se o Projeto de Requalificação Urbana da Vila de Jericoacoara, que previa a construção de um centro cultural e de turismo, um mercado público, creche, oficina de artesanato, centro esportivo, posto de saúde, posto policial, parque do cemitério, quiosques e serviços de terraplanagem, urbanização, pavimentação, paisagismo, sinalização de vias, estacionamento, além também de dar início à licitação para a implantação do sistema de esgotamento sanitário de Jericoacoara ${ }^{58}$.

Em 21/02/2000 foi eleita, na comunidade, uma Comissão de ContraProposta ao PDDU de Jericoacoara ${ }^{59}$, em assembléia popular promovida pela Comissão Especial de Regularização Fundiária e Instituto de Desenvolvimento Agrário do Ceará - IDACE (representado pelo técnico, Sr. Wilson Brandão), como forma de promover a participação local no estudo, discussão e

\footnotetext{
${ }^{57}$ Outros 3 projetos constantes no PDDU destacam-se: a) Via Paisagística e da Urbanização da Lagoa de Jijoca, b) Construção e Implantação de Edificações e Urbanização da Área de Caminho de Chegada e c) Projeto Executivo de Controle de Acesso à APA de Jericoacoara.

${ }^{58}$ Informação oficial do Governo do Estado, datada de 27/02/2002, disponível em <www.ceara.gov.br>.

${ }^{59}$ A Comissão foi composta de 13 membros efetivos e 5 suplentes.
} 
proposição de eventuais ajustes a serem feitos no PDDU conforme interesses da coletividade da vila.

A grande maioria dos ítens propostos pelo PDDU foram aprovados pela comunidade, e dentre as observações elaboradas pelos habitantes locais referentes a algumas de suas partes, destacam-se, conforme o documento "Comissão Comunitária de Contra-Proposta ao PDDU - Síntese dos Trabalhos" (outubro de 2000):

- Concordância com a "ampliação do atual Sistema de Terra VIII (vila de Jericoacoara ${ }^{60}$, com a ressalva de que deve ser realizado um estudo sobre os avanços das dunas móveis dentro da APA, a fim de garantir que nas próximas décadas, os ora favorecidos com a ampliação do Sistema de Terra VIII não percam suas propriedades";

- Em trecho do PDDU, lê-se: "As áreas remanescentes e vazios urbanos compreendidos no perímetro urbano são consideradas áreas institucionais para localização de equipamentos públicos, podendo também serem utilizadas para empreendimentos de interesse coletivo em parceria com a iniciativa privada". Frente à este parágrafo, localizado no ítem "Parcelamento do Solo", a comunidade sugeriu que o trecho final seja retirado, ou seja, onde se lê "em parceria com a iniciativa privada";

- No ítem "Equipamentos Especiais em Jericoacoara", o PDDU sugere a criação de um único portão de acesso à APA. A comunidade, em contra-proposta, sugere que sejam feitos três portões de entrada: 0 primeiro (e principal) seria o proposto pelo PDDU (relacionado ao caminho que interliga diretamente a vila à sede do município), mas que seja considerado também mais dois acessos já existentes e úteis

\footnotetext{
${ }^{60}$ Como já dito anteriormente, tanto a Instrução Normativa $\mathrm{n}^{\circ} 4$, de 15 de maio de 1992 , quanto a de mesmo número, de janeiro de 2001 (ambas do IBAMA), definem espacialmente, na APA de Jericoacoara, uma Zona de Vida Silvestre e oito Sistemas de Terras, sendo o povoado (vila de Jericoacoara) referente ao Sistema de Terras VIII. Em 1992, a área total deste Sistema de Terras era de
} 
à vila, referentes à interligação a duas praias (comunidades) vizinhas: Guriú e Preá, contando ainda, as três, com a construção de guarita e estacionamento;

- Quanto ao ítem "Melhorias de Acesso", a comunidade sugere que as vias de acesso à vila "sejam apenas demarcadas com piquetes, conservando seu piso natural (areia), sem sofrer nenhum tipo de melhoria de pavimentação. $\mathrm{O}$ acesso deve continuar como está, ou seja, apenas para veículos "off-road". Afinal, o veículo e o visitante é que devem se adequar ao acesso e à natureza, e não o contrário ${ }^{61 ” ;}$

- A comunidade rejeitou, por unanimidade, o ítem que permite acesso de veículos ao Serrote ${ }^{62}$, mesmo que por uma única trilha demarcada, pois o mesmo está, visivelmente, em processo de erosão. Sendo assim, sugere-se que "o acesso ao Serrote seja exclusivo para pedestres";

- No ítem "Espaço de Apoio aos Esportes Náuticos - Guarderia / Mirante / Guaderia de Barcos", a comunidade coloca-se estritamente contra a construção de um mirante artificial (projetado para ser construído em terreno particular), pois Jericoacoara já possui dois mirantes naturais: o Serrote e a Duna do Pôr do Sol. Além disso, tratando-se de terreno particular, a construção de tal empreendimento deveria estar "de acordo com os trâmites legais exigidos pelo IBAMA e demais órgãos. E, não tendo o privilégio de englobar seu projeto particular dentro de um PDDU público. Todos os moradores de Jericoacoara submetem-se aos critérios rígidos do IBAMA para viabilizar seus projetos particulares. Sendo assim, a comissão não vê porque ser diferente nesse caso";

$0,41 \mathrm{~km}^{2} \mathrm{e}$, em 2001 , ampliou-se para $0,78 \mathrm{~km}^{2}$, delimitada por uma poligonal cujo perímetro mede $3.525,33 \mathrm{~m}$.

${ }^{61}$ Nota-se, no decorrer desta pesquisa, que a população local de Jericoacoara é marcadamente contra a pavimentação de vias de circulação na vila e, também, das de acesso à mesma. Esta posição nada tem a ver com a eventual pavimentação e/ou melhorias nas estradas estaduais de acesso à sede do município (Jijoca de Jericoacoara, localizado cerca de $18 \mathrm{~km}$ da vila de Jericoacoara).

${ }^{62}$ Formação dunar fixada por vegetação, localizada na área do Parque Nacional, e não na APA (área correspondente à vila de Jericoacoara). 
O Plano Diretor de Desenvolvimento Urbano do Município de Jijoca de Jericoacoara é composto juridicamente, ainda, de seis leis, a saber: 1) Lei de Diretrizes Urbanas, 2) Lei de Organização Territorial, 3) Lei de Parcelamento, Uso e Ocupação do Solo 4) Lei do Sistema Viário, 5) Lei Ambiental e 6) Código de Obras e Postura.

Da mesma forma, a Comissão de Contra-Proposta ao PDDU, apresentada pela comunidade da vila de Jericoacoara, apresentou algumas observações à respeito destas leis. Algumas delas sugeriam complementações e/ou alterações textuais no sentido de se garantir uma maior participação dos habitantes nas discussões políticas locais, buscando-se um processo democrático e participativo quanto à elaboração e execução do PDDU no município. Outras, diziam respeito à circulação (proibição de veículos em áreas frágeis, como as dunares e o Serrote) e aos limites na construção de residências, bares, restaurantes, lojas, pousadas, entre outros, afim de se controlar a verticalização e a expansão da área urbana da APA (vila), destacando-se:

- Quanto ao Projeto de Lei de Parcelamento, Uso e Ocupação do Solo, a Comissão não aprovou o texto (art. 12): "As construções terão altura máxima de 7,5 $\mathrm{m}$ (sete metros e cinqüenta centímetros), compostas por dois pavimentos...". Desta forma, sugeriu-se nova redação à este artigo: "O gabarito máximo de altura das edificações será sempre de 1 (um) pavimento, e a edificação jamais terá altura superior a 5,0 m (cinco metros), a partir do nível de soleira (base)". A justificativa apresentada foi de que construções deste porte viriam a descaracterizar totalmente a APA de Jericoacoara, como também proporcionariam a duplicação da área de construção ( 2 pavimento), acarretando assim um aumento vertiginoso da capacidade de hospedagem e por conseqüência das demandas à ela intrínsecas (ou seja, um turismo massificado); 
- No PDDU, o item 7.2.7 (Plano de Estruturação Urbana, em conformidade com a Instrução Normativa no4 do IBAMA, de 1992) há a seguinte redação: "Fica limitado o número de pousadas, hotéis e assemelhados ao atualmente existente". A Comissão de ContraProposta possui uma posição contrária à este item, justificando-se do seguinte modo: "A comissão entende que a restrição para construção de pousadas não faz mais sentido, uma vez que a presente restrição não conseguiu impedir o aumento da oferta de leitos em Jericoacoara durante os últimos oito $a_{n o s}{ }^{63}$, seja pela expansão das pousadas existentes ou pela construção de "pousadas residenciais", sendo assim, a comissão sugere que 0 item acima seja retirado do texto, adequando o mesmo à realidade e permitindo que os meios de hospedagem existentes sejam corretamente cadastrados e regulamentados".

A Instrução Normativa no4 do IBAMA (de 1992) sofreu propostas de alteração pelos urbanistas e técnicos responsáveis pela elaboração do PDDU, e as mesmas foram todas aprovadas pela Comissão de Contra-Proposta, exceto sobre o item acerca da proibição de barcos à motor no mar (concordase sua proibição em lagoas), justificando-se a importância dos mesmos em resgates (apoio à prática de esportes náuticos).

A análise do PDDU (que, por ser um documento extenso - contendo mais de 1000 páginas - durou cerca de oito meses) pela comunidade foi, como se pode perceber, minuciosa e participativa, fruto de reuniões onde ocorriam a leitura do Plano, discussão e posterior votação dos pontos abordados, finalizando-se com a elaboração de atas. Em sua maioria, os membros representantes da Comissão de Contra-Proposta ao Plano Diretor de Jericoacoara eram pessoas nativas do lugar, mas contavam também com atuais moradores (e proprietários de estabelecimentos) provenientes de outros lugares e com formação diversa, como é o caso de uma advogada, proveniente

\footnotetext{
${ }^{63}$ Uma vez que este documento é datado em outubro de 2000, este período compreende, portanto, de
} 1992 até esta data. 
de São Paulo, proprietária de pousada e residente em Jericoacoara há cerca de doze anos, que muito contribuiu nas discussões pelo seu embasamento jurídico e, declaradamente, pelo seu apego e preocupação com a sustentabilidade do lugar.

Conforme informações obtidas na comunidade, a Contra-Proposta foi apresentada em tempo hábil ao órgão estadual responsável, a SEINFRA (Secretaria de Infra-Estruturas do Estado do Ceará), mas esta, aparentemente, ignorou o documento elaborado pela comunidade e, em novembro de 2000 (cerca de um mês após a conclusão do documento referente a contraproposta), o Plano Diretor foi votado e aprovado pela Câmara Municipal de Jijoca de Jericoacoara, sem considerar as posições apresentadas pela comunidade.

O início do estado de tensão e intensa mobilização da população, representada pelo Conselho Comunitário de Jericoacoara, se deu em 22 de dezembro de 2000, com a obra de construção do que era para ser, originalmente, o Centro de Visitantes. Este empreendimento foi muito criticado devido à sua localização ao centro da Rua Principal, a um quarteirão da praia. Como esta rua termina na praia, esta construção impossibilita a vista que se tinha para o mar (no final das tardes era comum os moradores sentarem-se em frente as suas casas para a contemplação do pôr do sol no mar). Mesmo apelando-se ao Ministério Público para evitar que o IBAMA (órgão gestor de Jericoacoara como Área de Proteção Ambiental) permitisse esta construção, a reivindicação de uma mudança de localização do Centro de Visitantes não foi atendida. Afirmando-se que "os insatisfeitos são poucos", o coordenador do IBAMA naquele momento, Sr. Romeu Aldigueri Arruda Coelho ${ }^{64}$, justificou que a localização seria estratégica para que o acesso à praia por veículos automotivos fosse bloqueada, e declarou: "Quem quer contemplar o mar em Jericoacoara vai para o serrote, para a duna ou para a praia". Esta obra tornouse escritório local do IBAMA e, atualmente, abriga a Associação de Bugueiros de Jericoacoara. 


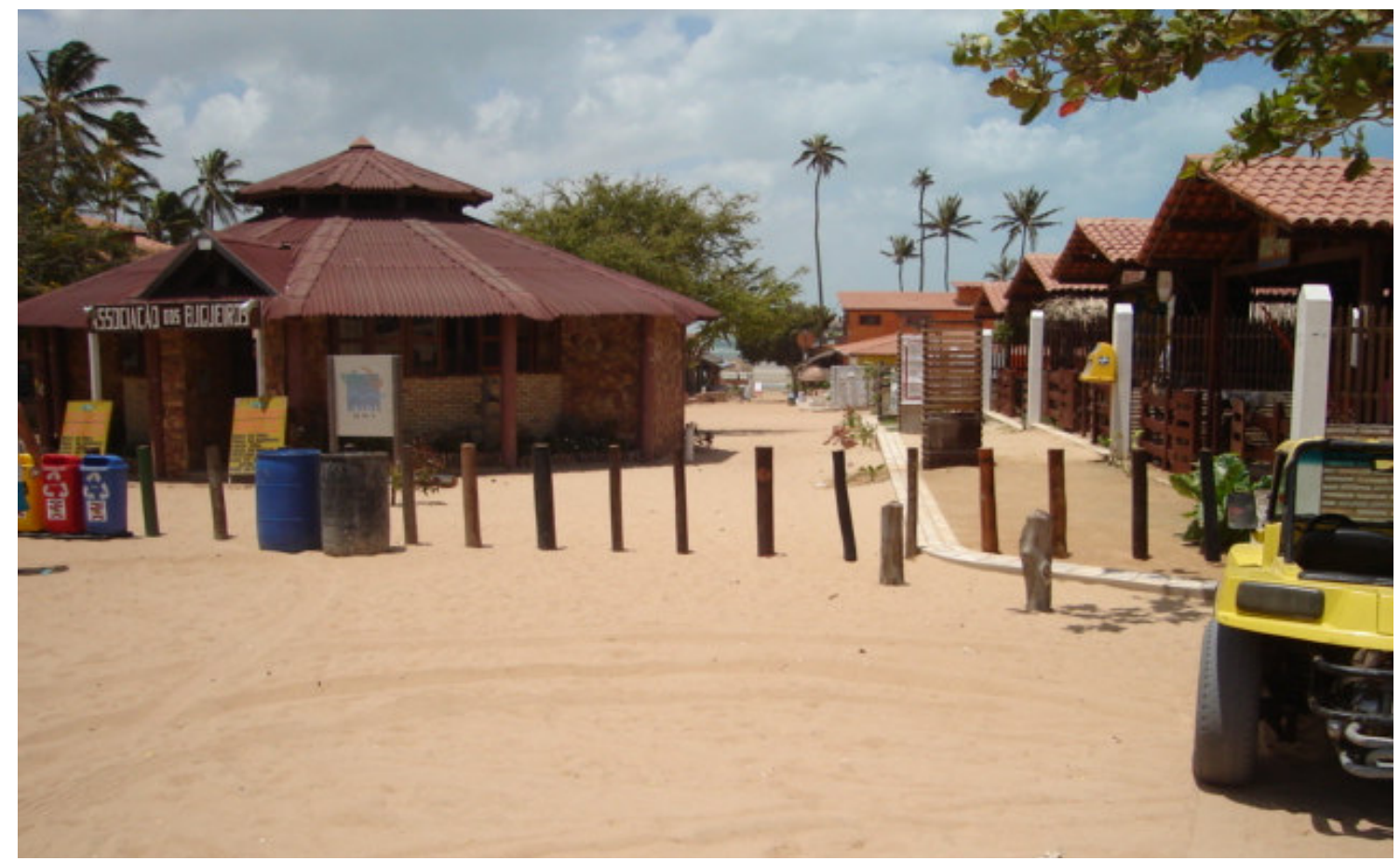

Fig. 17 - Obra localizada no centro da Rua Principal bloqueando-se a visão do mar (Fabio S. Molina, 2005)

Outro momento crítico foi quando houve a liberação da construção de novos hotéis e pousadas (proibidos desde $1992^{65}$ ) e a alteração do limite vertical das construções de 1 pavimento (4 metros) para 2 pavimentos (7,5 metros) ${ }^{66}$. A Instrução Normativa (IN) do IBAMA de 1992 foi revogada em 2001, seguindo as disposições do Plano Diretor de Jijoca de Jericoacoara, recém aprovado. A liberação para construção de novos hotéis e pousadas e a permissão à construção de segundo piso talvez tenham sido as medidas mais preocupantes para as lideranças locais, que se encontram numa posição totalmente contrária à verticalização e à possibilidade de um aumento significativo do número de leitos nas pousadas, o que poderia acarretar na descaracterização do local (arquitetônica e social/cultural) e num uso turístico maior do que a vila pudesse comportar, além de possíveis desequilíbrios ambientais.

\footnotetext{
${ }^{64}$ Em entrevista ao jornal "O Povo" (Fortaleza), em 31 de janeiro de 2001.

${ }^{65}$ BRASIL. Ministério do Meio Ambiente. IBAMA. Instrução Normativa n.4, de 15 de maio de 1992.

${ }^{66}$ BRASIL. Ministério do Meio Ambiente. IBAMA. Instrução Normativa n.4, de janeiro de 2001.
} 
Em suma, revogou-se a IN no4 de 1992, que proibia, entre outras coisas, a construção de novos hotéis e pousadas ${ }^{67}$ a construção de 2 pavimentos e também piscinas, e criou-se uma nova IN no4 (em 2001), atendendo ao ideal de uma urbanização (fundamentalmente turística) da vila de Jericoacoara em conformidade com o PDDU (e o Projeto de Requalificação Urbana da Vila de Jericoacoara), elaborado e executado sem a devida participação da sociedade ${ }^{68}$.

Ao fragilizar as normas de proteção da vila, criou-se, em seguida (04/02/2002), o Parque Nacional de Jericoacoara (que circunda a vila / APA de Jericoacoara), com o intuito de preservar uma área (que já era protegida enquanto APA). Conforme lideranças locais, para confundir a opinião pública nacional com o que realmente estava acontecendo no local, associa-se à criação do Parque à "salvação" de Jericoacoara. Na verdade, o Parque implicou em poucos resultados práticos.

A questão talvez mais positiva acerca do PARNA seja a contenção do avanço urbano sobre as áreas não pertencentes ao Sistema de Terras VIII (APA de Jericoacoara), já que é proibido, por lei, a presença de moradores em áreas de Parque Nacional. Um motivo de crítica refere-se ao impedimento da pesca artesanal praticada por nativos, pois o PARNA estende seus limites $1 \mathrm{~km}$ mar adentro.

\footnotetext{
${ }^{67}$ Conforme texto da IN de 1992, ítem 7.2.7, "Fica limitado o número de pousadas, hotéis e assemelhados ao atualmente existente" (grifo nosso).

${ }^{68}$ Após aprovado o PDDU, o Governo do Estado do Ceará encaminhou ofício ao IBAMA/DF, pedindo a adequação da Instrução Normativa ao que se foi determinado pelo Plano Diretor. Portanto resolveu-se a questão deste dispositivo legal federal, hierarquicamente superior ao PDDU, editando-se um novo em sintonia com o mesmo.
} 


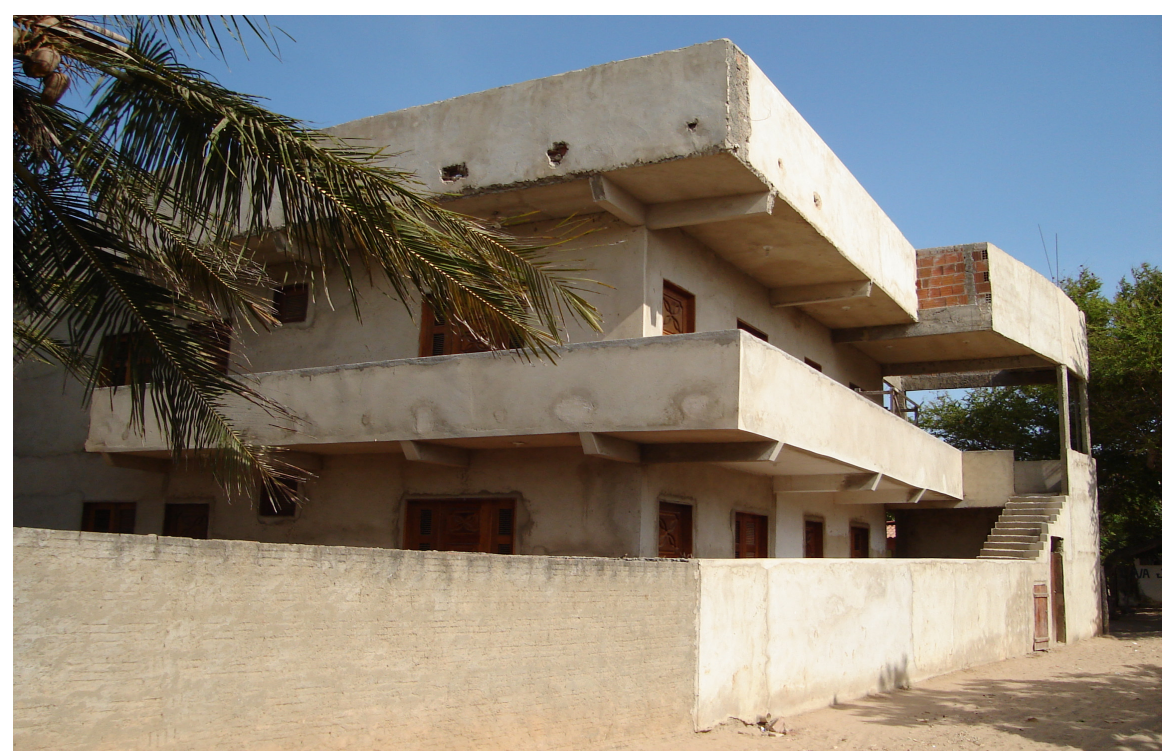

Fig. 18 - Construção de 2 pavimentos na vila (Fabio S. Molina, 2005)

O governo cearense sinaliza também para a realização de diversas obras e medidas estruturantes que permitam que Jericoacoara receba um maior fluxo turístico, com destaque para o possível asfaltamento do acesso até a sede do município de Jijoca de Jericoacoara e a construção de um aeroporto regional (ainda não realizados). Em áreas naturais de difícil acesso (ou com um acesso controlado), lembra Roberto $\mathrm{C}$. Boullón: uma vez "que se melhorem ou se construam estradas e aeroportos e se estabeleçam meios de transporte turístico, corre-se o risco de que qualquer um desses lugares [...] sofra 0 impacto negativo de uma exploração irracional” (2002, p. 237).

As medidas de requalificação urbana em Jericoacoara fundam-se em um discurso político acerca das melhorias infra-estruturais no lugar, mas consideráveis impactos sócio-ambientais tornam-se presentes, alguns noticiados tanto pela imprensa como também pelo movimento "SOS JERI"69, que surgiu como reação à ações impactantes realizadas na vila, como a derrubada de coqueiros para a terraplenagem. Conforme informações contidas no website do SOS JERI acerca da ausência da participação da comunidade na elaboração do Plano Diretor (decidido exclusivamente entre a Prefeitura Municipal e o Governo do Estado do Ceará, através da SEINFRA), "a suposta participação popular foi justificada por estes órgãos apenas por um abaixo

\footnotetext{
${ }^{69}$ Disponível em: $<$ http://planeta.terra.com.br/turismo/sosjeri $>$. Acesso em 25/01/2004
} 
assinado que a prefeitura circulou rapidamente pela vila. Os nativos que assinaram este documento foram convencidos sob o argumento de que eles seriam beneficiados com a liberação da construção de dois pavimentos, pois poderiam montar o seu comércio no térreo e ter o piso superior como moradia, ou ampliar sua residência para um segundo andar quando a família aumentasse. Hoje existe um sentimento de revolta por parte desses nativos em relação ao abaixo assinado, quando eles souberam que na verdade não poderiam fazer o segundo pavimento (o Plano Diretor exige 50\% de área livre no terreno para a construção do segundo pavimento, e a maioria das casas dos nativos situa-se em terrenos pequenos), e portanto os únicos beneficiários com o abaixo assinado e as normas do Plano Diretor seriam os proprietários de terrenos maiores, ou seja, os empresários estabelecidos no local.

Mesmo contrariamente às reivindicações da comunidade local, e alegando-se que o projeto já estava pronto, aprovado e não poderia sofrer alterações, o Governo do Estado do Ceará inicia, em maio de 2002, as obras previstas no Projeto de Requalificação Urbana da Vila de Jericoacoara (que objetiva "estruturar a Vila de Jericoacoara para atender às necessidades primordiais do turismo na região"), com licença para construção emitida pela Superintendência Estadual do IBAMA. As obras (cujo prazo estipulado para o término era de 6 meses) eram administradas pela Prefeitura Municipal de Jijoca de Jericoacoara e o Projeto tinha como empreendedor a Secretaria de InfraEstrutura do Estado do Ceará (SEINFRA), e por executora a empresa licitada, denominada Fujita Engenharia Ltda, com sede em Fortaleza.

É notável a conivência da Prefeitura Municipal de Jijoca de Jericoacoara com as ações do Governo do Estado do Ceará relativas à urbanização e ao processo de descaracterização da praia de Jericoacoara. Por outro lado, um certo descaso da municipalidade com a vila, a exemplo, a especulação imobiliária, a problemática dos resíduos sólidos acumulados, além da pouca disponibilidade e qualidade da água e do saneamento básico, um posto de saúde ineficiente, e principalmente a falta de articulação com outros órgãos públicos (Ibama, Governo do Estado, entre outros) para evitar-se a ocupação desordenada e o processo de descaracterização da vila a favor de um turismo 
massificado (que, obviamente, traria mais recursos ao município, fazendo com que empresários recebam um incentivo para investir em Jericoacoara).

Frente a este certo estado de abandono, Jericoacoara procura encontrar no Conselho Comunitário uma saída para os problemas decorrentes da urbanização (turística) de um lugar que é, contraditoriamente, uma unidade de conservação. Conforme Daniel Lins ${ }^{70}$, "Jericoacoara vive uma grande contradição: de um lado, o Conselho Comunitário, antenado à modernidade, inserido na política ecológica e na indústria do turismo e, de outro, um prefeito antiquado, sem vínculos nem com Jeri nem com a questão do turismo ecológico, riqueza inestimável do Ceará".

O termo "vinculo" refere-se ao fato de o prefeito ser de origem espanhola, atualmente na terceira gestão do município, e proprietário da segunda pousada construída na vila, no início da década de 1980 (hoje, possui duas pousadas). Sérgio Herrero Gimenez elegeu-se primeiro prefeito em 1991 (com a emancipação do município), reelegendo-se nas eleições de 2000 e também na de 2004. Esta última candidatura, sob decisão da justiça eleitoral, foi impugnada (temporariamente, por ter ganho causa após recorrer da decisão do juiz da 30" Zona Eleitoral, Magno Gomes) por motivos de improbidade administrativa, emitida pelo Tribunal de Contas dos Municípios (TCM).

Logo após o início das obras em Jericoacoara, em 24 de junho de 2002, e por pressão do Conselho Comunitário (com o apoio do Dr. Paulo Henrique de Freitas Trece, Promotor de Justiça do Ministério Público do Estado do Ceará, e do Dr. Alessander Wilckson Cabral Sales, Procurador Regional dos Direitos do Cidadão da Procuradoria da República no Estado do Ceará), as obras foram paralisadas por 15 dias, para que peritos do Ministério Público Federal realizassem uma vistoria nas construções do Projeto, ocorrida nos dias 03 e 04 de julho de 2002. O objetivo era avaliar as repercussões ambientais dos projetos e emitir um laudo técnico conclusivo acerca da necessidade ou não da exigência de EIA/RIMAS para cada um dos empreendimentos licenciados pelo IBAMA. Naquele momento, algumas obras ainda não tinham sido iniciadas,

\footnotetext{
${ }^{70}$ Sociólogo, professor da Universidade Federal do Ceará (UFC), em artigo publicado no jornal "O Povo", intitulado "Ai de ti, Jericoacoara" (Fortaleza, 14 de janeiro de 2001).
} 
como o "Centro Esportivo" (esta área estava sendo utilizada somente como canteiro de apoio às obras e alojamento de pessoal), o "Centro de Cultura e Turismo", o "Quiosque/Baia de Cavalos para Pesseio" e o Parque do Cemitério (executada apenas a terraplenagem do arruamento de contorno); o calçamento de partes da vila e outros equipamentos (Estacionamento, Posto Policial, Posto de Saúde, Oficina de Artesanato, Creche, Mercado Público, Urbanização de Largos) estavam sendo implantados de forma simultânea. O que se podia presenciar, conforme depoimento de alguns moradores, era a vila sendo transformada num "verdadeiro canteiro de obras".

O laudo técnico conclusivo elaborado pelos peritos do Ministério Público Federal (10 de julho de 2002) acerca das irregularidades verificadas na vistoria das construções citadas anteriormente apresentou a real necessidade de um estudo de impacto ambiental que deveria ter sido realizado antes do início da construção dos empreendimentos previstos no Plano Diretor (Projeto de Requalificação Urbana de Jericoacoara). Detectou-se a ausência de procedimento de licenciamento ambiental para a ampliação/implantação dos arruamentos e, ainda, o licenciamento ambiental das obras, emitido pelo IBAMA, se deu em modalidade não prevista em lei. Conforme o laudo,

As "Licenças para Construção" emitidas pelo IBAMA consideraram os equipamentos de maneira isolada, deixando de observar os aspectos da proximidade e/ou sequência de equipamentos e da simultaneidade da implantação e futura operação, que marcam o Projeto. Logicamente, esses aspectos imprimem uma atuação sinérgica dos impactos, que escapou da avaliação individual dos equipamentos promovida pelo IBAMA, e requerem a execução de estudos mais elaborados.

Os procedimentos de "Licença para Construção" conduzidos pelo IBAMA são desprovidos de avaliações ambientais acerca do "Projeto de Requalificação Urbana da Vila de Jericoacoara". Nos sintéticos laudos técnicos, elaborados para cada um dos equipamentos, constam apenas algumas poucas informações acerca da topografia e da cobertura vegetal da área. Em todos os laudos os técnicos concluem que "do ponto de vista ambiental" não vêem "impedimentos para a instalação e operação dos equipamentos".

Ademais, o instrumento utilizado pelo IBAMA em resposta a uma solicitação de licença ambiental pela SEINFRA - "Licença para Construção" - não se encontra entre aqueles previstos em legislação. A forma de condução e as licenças a serem expedidas pelo órgão ambiental encontram-se estabelecidas 
no artigo 19 do Decreto no 99.274, de 6 de junho de 1990, que, dentre outros, regulamenta a Lei no 6.938, de 31 de agosto de 1981, que dispõe sobre a Política Nacional do Meio Ambiente.

O laudo apresenta ainda a Resolução CONAMA no 10, de 14 de dezembro de 1988, a qual afirma serem proibidas, nas APAs, atividades de terraplenagem que venham causar danos ao meio ambiente e/ou perigo para pessoas ou para a biota (artigo $6^{\circ}$ ) e, também, em seu artigo $8^{\circ}$, que nenhum projeto de urbanização poderá ser implantado numa APA, sem a prévia autorização de sua entidade administradora, que exigirá, entre outros, a implantação de sistema de coleta e tratamento de esgotos (em Jericoacoara, esse sistema ainda não havia sido implantado).

Após conclusão do laudo, fruto de uma Ação Civil Pública e assinatura de um Termo de Ajustamento de Conduta $(T A C)^{71}$, deu-se o embargo do calçamento da vila e também de alguns empreendimentos. Todavia, em decorrência da elaboração posterior de um estudo de viabilidade ambiental, deu-se continuidade a algumas obras a partir do início de 2004.

Segundo determinado no TAC, o IBAMA/CE é o órgão licenciador competente, uma vez que as obras do Plano de Requalificação Urbana estão sendo executadas em Unidade de Conservação Federal, ou seja, na Área de Proteção Ambiental de Jericoacoara. Assim, coube ao IBAMA/CE reiniciar todo o procedimento administrativo de licenciamento ambiental, tornando sem efeito as licenças ambientais anteriormente concedidas para cada obra individualmente considerada, posto que a crítica maior ao IBAMA/CE foi justamente o fato de ter concedido licenciamento ambiental das obras através de cada equipamento individualmente, e não como um todo, desconsiderandose portanto a sinergia dos impactos decorrentes da construção de todos os equipamentos propostos. Ainda conforme o TAC, é de responsabilidade do

\footnotetext{
${ }^{71}$ O TAC é datado em 15 de julho de 2002, assinado por representante do Ministério Público Federal (Procurador da República, Sr. Alessander Wilckson Cabral Sales), do IBAMA/CE (Gerente Estadual, Sr. Romeu Aldigueri de Arruda Coelho), pelo Prefeito do Município de Jijoca de Jericoacoara, Sr. Sérgio Herrero Gimenez e pelo Sr. Paulo Rubens Fontenele Albuquerque, Secretário do Estado de Infra-Estrutura do Ceará - SEINFRA.
} 
IBAMA/CE a exigência, perante os empreendedores das obras ${ }^{72}$, de um Estudo de Viabilidade Ambiental e, também, de submeter todas as decisões técnicas e administrativas acerca dos procedimentos administrativos de licenciamento ambiental a uma prévia análise técnica do Ministério Público Federal, através de sua 4⿳亠丷厂 Câmara de Coordenação e Revisão.

Em 06 de janeiro de 2005 o Governo do Estado do Ceará informou estarem prontas as obras de requalificação urbana da Vila de Jericoacoara. Estas representaram um investimento de $\mathrm{R} \$ 7.896 .210,37$, recursos referentes à compra dos terrenos e realização das "benfeitorias" aos habitantes. Foram concretizadas a construção do mercado público com $230 \mathrm{~m}^{2}$ de área divididos em 12 boxes; creche com $340 \mathrm{~m}^{2}$ de área, com capacidade para 50 crianças; oficina de artesanato com $650 \mathrm{~m}^{2}$ de área (2 salas de aula, 1 oficina, 1 sala de exposição, 2 banheiros e 2 lanchonetes); posto de saúde com $350 \mathrm{~m}^{2}$ de área construída; estacionamento para 256 vagas; posto policial com $105 \mathrm{~m}^{2}$ de área construída; urbanização e passeios de contorno das vias com 4.100 m²; e demarcação da poligonal de contorno da vila (piquetes) com 2.150m. Resta, ainda, a implementação da rede de esgotamento sanitário.

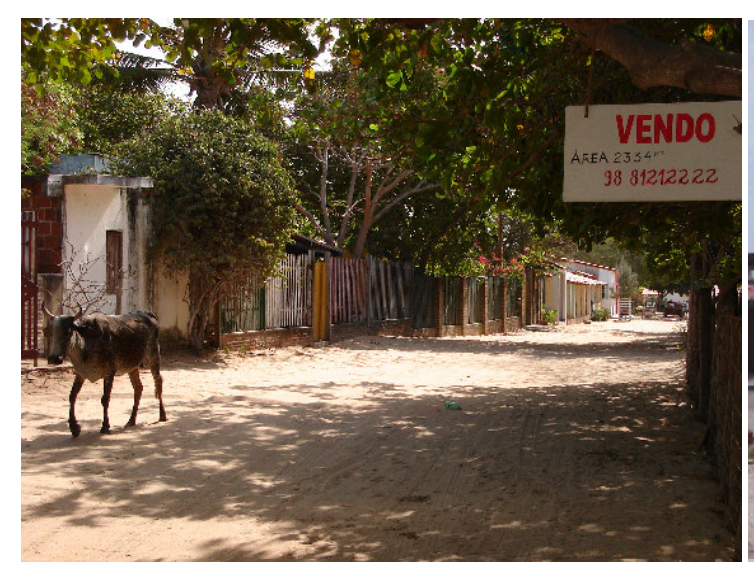

Fig. 19 - Aspecto bucólico de uma rua na vila (detalhe para animais na rua e placa indicando venda de terreno) (Fabio S. Molina, 2005).

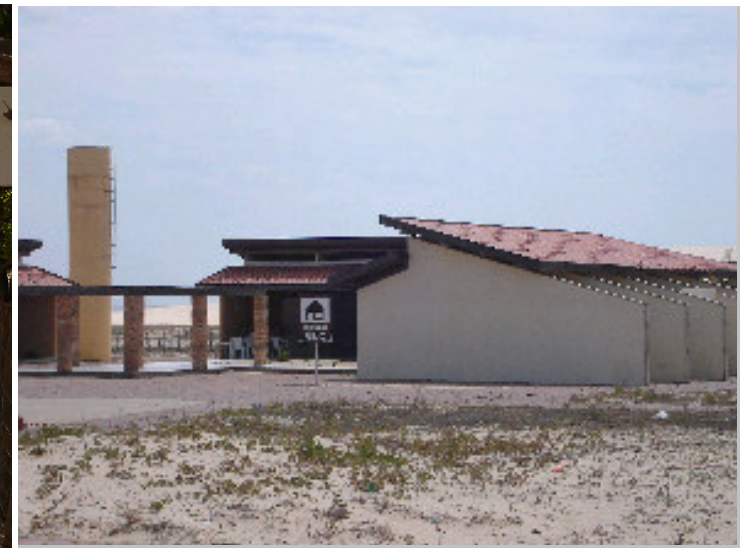

Fig. 20 - Mercado Público e Centro de Artesanato (obras inauguradas, mas sem funcionamento) (Fabio S. Molina, 2005).

\footnotetext{
${ }^{72}$ Representados pelo Estado do Ceará, através da SEINFRA e o Município de Jijoca de Jericoacoara.
} 


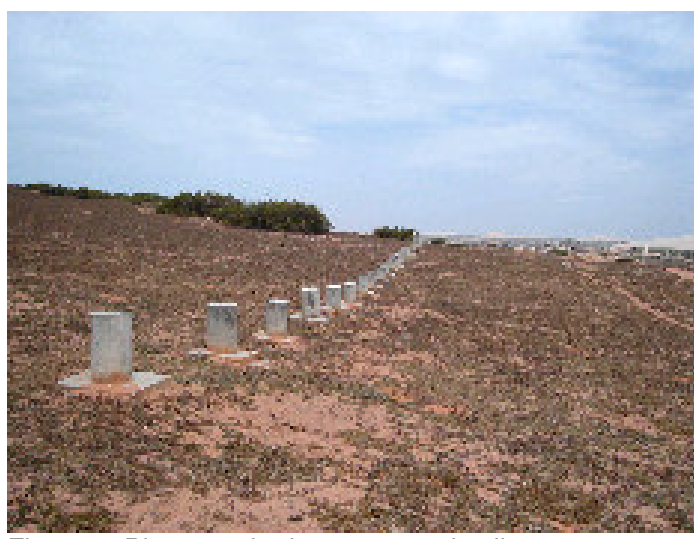

Fig. 21 - Piquetes de demarcação da vila (Fabio S. Molina, 2005)

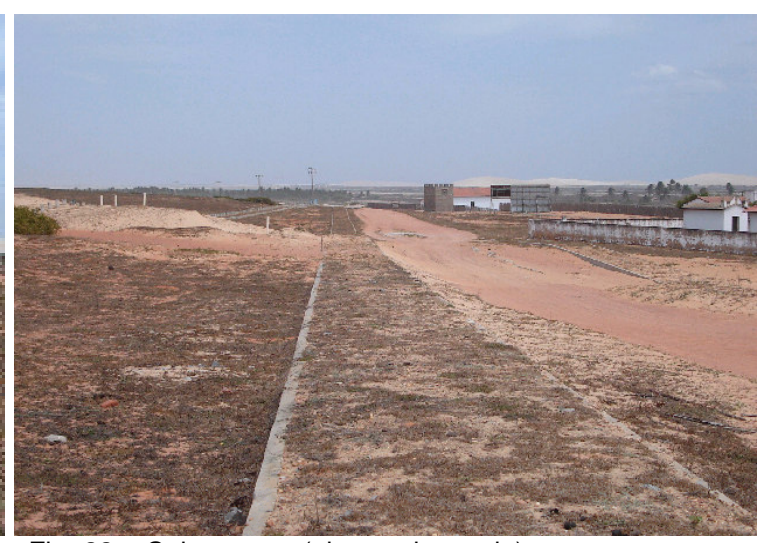

Fig. 22 - Calçamento (obra embargada) (Fabio S. Molina, 2005)

Ressalte-se o importante papel da comunidade local referente à sua resistência perante ações hegemônicas que se impõem ao lugar. Tal constatação nos remete à afirmação de Foucault segundo o qual não há "relações de poder sem resistências"73. Estas resistências são reveladoras de embates relativos ao uso do espaço e reveladoras, também, do papel da comunidade local como sujeito ativo na luta contra o "turismo predador", a grilagem de terras, a especulação imobiliária, a degradação dos recursos naturais, entre outros conflitos emergentes das contradições impostas por sujeitos sociais hegemônicos e vividas por sujeitos sociais hegemonizados. Conforme depoimento da Presidente do Conselho Comunitário, Maria Filizolina de Souza, existe em Jericoacoara um forte conflito de responsabilidades, na medida em que é difícil observar um determinado órgão público assumindo responsabilidade perante determinada ação impactante na vila: ora a "culpa" é da Prefeitura, ora do IBAMA, ou do Governo do Estado, via SEMACE, SEINFRA, SETUR, entre outros.

O conselho foi criado em 1984, mesma época em que Jericoacoara tornou-se APA, com o intuito, à época, de se controlar o aumento do número de pousadas, buscando-se manter a vila da forma mais rústica possível. $\mathrm{O}$ Conselho contou com a atuação, na sua revitalização (em 1994), da médica

\footnotetext{
${ }^{73}$ Citado por Harvey (2004, p. 50).
} 
sanitarista Denise Cury ${ }^{74}$ que, entre outras coisas, coordenou a implantação do sistema de coleta e tratamento de resíduos sólidos, além de atuar no serviço de saúde e na luta contra o crescimento urbano (des)ordenado da vila. Atualmente, o Conselho encontra-se bastante enfraquecido devido a perseguições a alguns membros e, ainda, devido à ausência de apoio de parte da comunidade que, pelas possibilidades de rentabilidade econômica proporcionada pelo desenvolvimento do turismo na vila, são favoráveis a ações impostas ao local; há também aqueles que apresentam uma postura neutra frente aos acontecimentos em Jericoacoara e preferem, portanto, não se envolver nos trabalhos do Conselho Comunitário.

Além de melhorias infra-estruturais urbanas e nas vias de circulação, a construção do Aeroporto de Parazinho (município de Granja), distante cerca de $37 \mathrm{~km}$ da sede do município de Jijoca de Jericoacoara, provavelmente contribuirá para intensificar o número de turistas. Essa medida contraria ambientalistas e parte da população, por tratar-se de uma área que apresenta frágeis ecossistemas litorâneos, sendo estes "mais suscetíveis à degradação, apesar de terem sido, num primeiro momento, recursos básicos para a captação dos projetos turísticos" (Rodrigues, 2001, p. 95). De acordo com o Relatório Técnico do Plano de Desenvolvimento Integrado do Turismo Sustentável (PDITS) do Pólo Ceará Costa do Sol (2004, p. 10), a construção do aeroporto, tendo como o argumento ö movimento de interiorização do turismo" não apresenta uma justificativa coerente com os objetivos do PRODETUR/NE II (no que tange à restrição à abertura de novas frentes para o turismo):

Nota-se que o projeto do aeroporto não é compatível com nível de demanda atual constatada na Área de Planejamento. E, ainda, esse empreendimento somente se justificaria perante um estudo de demanda regional, posto que está prevista a ampliação do aeroporto de Parnaíba, no Estado do Piauí, visando integrar o roteiro turístico entre Jijoca de Jericoacoara, Delta do Parnaíba e Lençóis Maranhenses.

\footnotetext{
${ }^{74}$ Ex-moradora de Jericoacoara, a paulista Denise Cury tornou-se residente na vila em 1993, prestando seus serviços médicos no Posto de Saúde, àquela época, administrado e coordenado pelo Conselho Comunitário. Passou a se envolver nas discussões acerca das construções desenfreadas (principalmente pousadas) que vinham ocorrendo na vila e, em 1994, tornou-se secretária do Conselho Comunitário de Jericoacoara, atuando fortemente na sua revitalização e nas discussões junto ao poder público acerca das normas impostas na vila, principalmente em 2001 com as mudanças da Instrução Normativa $n^{\circ} 4$, do IBAMA.
} 
Trata-se de mais uma das contradições da atividade turística na qual, ao mesmo tempo em que se dinamiza a economia, um considerável número de impactos negativos de outras naturezas se impõem aos lugares dos quais se apropria. O que está em curso é a expansão desenfreada do capital, que "dissolve relações de produção, transformando-as ao desenvolvê-las subordinadamente às suas tramas reprodutivas, inscrevendo-lhes novos conteúdos e sentidos [e impondo] o seu domínio às fontes originais de riqueza, o que inclui, além do trabalho, a natureza" (Martins, 2001, p. 23-24).

Estudo realizado por Matias e Silva (2001, p. 28), com o apoio do IBAMA, atenta para o fato de que "o acesso indiscriminado de automóveis a todas as regiões da APA de Jericoacoara contribui também para a degradação do solo e da vegetação, devendo o trânsito ter um ordenamento compatível com a capacidade de suporte do ambiente e as necessidades econômicas da APA".

Além da preocupação com a perda da qualidade paisagística e desequilíbrios ecológicos, a questão da qualidade de vida da população e da preservação da cultura local são também fatores preocupantes assinalados pelos que apresentam resistência ao progresso do turismo na região e contrários ao turismo de massa. Por outro lado, uma boa parte dos habitantes é adepta ao desenvolvimento do turismo, cabendo ressaltar que:

...a possibilidade da população local obter autonomia econômica com a atividade turística impõe a constatação de que a idéia de um neo-colonialismo não se sustenta. Por outro lado, aqueles que se põem em defesa da preservação das comunidades locais, tradicionais, incluindo aí a manutenção de uma economia de subsistência, arcaica, incorrem, mais do que os primeiros, à uma concepção colonialista de distanciamento e exclusão dos grupos tradicionais" (Luchiari, 1998, p. 20).

O mesmo afirma Lima (2002, p. 187-188) ao analisar as comunidades pesqueiras marítimas no território cearense:

$\mathrm{Na}$ atualidade, a diversidade produtiva amplia-se (juntamente com a inclusão de atividades vinculadas ao turismo) no sentido 
dos moradores dessas comunidades buscarem garantir as condições de reprodução da vida, procurando criar alternativas para satisfazer as necessidades básicas e, se possível, alguns desejos outros (de consumo).

Representantes dos governos do Ceará, Piauí e Maranhão discutem a criação de um corredor turístico abrangendo os três Estados (projeto Roteiro Turístico Integrado CEPIMA), integrando os destinos de Jericoacoara, Delta do Parnaíba e Lençóis Maranhenses, através do PRODETUR II, em parceria com empresários do ramo de empreendimentos turísticos (principalmente investidores italianos), com o Banco no Nordeste, Ministério do Turismo e com o Sebrae ${ }^{75}$. Além disso, segundo notícia do jornal "Diário do Nordeste" (de 10/03/2005), a EMBRATUR, através do projeto "Caravana Brasil", desenvolveu um plano de promoção turística de Jericoacoara (entre outros destinos), promovendo a ida de dez operadoras brasileiras para conhecer de perto os atrativos turísticos cearenses, visando o aumento do fluxo de turistas, principalmente estrangeiros.

Pode-se auferir, contudo, que tanto a produção local do turismo em Jericoacoara quanto em partes do território de outros estados nordestinos é marcada, nos seus diversos níveis escalares, por ações do poder público (por meio de políticas, programas e projetos turísticos) que, apesar de apresentarem um discurso com foco na sustentabilidade socioambiental, inserem-se na lógica do mercado. Isto revela, especificamente em Jericoacoara, uma contradição, intrinsecamente relacionada ao consumo da natureza e sua valorização remetendo-nos à idéia de que "o espaço onde é possível encontrar a 'paisagem natural intocada' é transformado para ganhar outro uso e ser consumido como sendo extensão do urbano" (Santana, 2001, p. 179).

\footnotetext{
${ }^{75}$ Serviço Brasileiro de Apoio às Micro e Pequenas Empresas.
} 


\section{5. Á GUISA DE CONCLUSÃO - O TURISMO E SEU LUGAR NA PRODUÇÃO DO ESPAÇO}

O espaço geográfico é formado por objetos e ações, determinados e comandados por relações sociais que nele se materializam, ou seja, que se realizam enquanto relações espaciais. Desta forma, esforços foram realizados neste trabalho com o intuito de desvendar as relações sociais e espaciais (dialeticamente inseparáveis e interdependentes) para a compreensão da realidade, buscando apreender também a atuação do capital, do Estado e da sociedade no processo de produção do espaço pelo e para o turismo, a partir da análise de um lugar: a vila de Jericoacoara.

O turismo apresenta-se como um fenômeno criador de uma (des)ordem espacial, na medida em que está inserido numa sociedade cada vez mais submetida à lógica do consumo. Esta atividade (baseada na especulação) impõe aos territórios dos quais se apropria um novo sistema de objetos e ações, para que assim se dêem as condições necessárias à sua realização (traduzindo-se na produção dos territórios turísticos, ou seja, um novo sentido é determinado ao uso do território). Daí a (des)ordem espacial criada pelo turismo, que se impõe aos lugares como uma verticalidade desestabilizadora de uma ordem pré-existente. Neste sentido, as transformações espaciais (manifestadas fisicamente nos lugares onde ocorre a especialização turística) evidenciam-se basicamente com a implantação de infra-estruturas e com a intensificação da circulação, em sentido amplo.

Com o uso do território, são criadas interdependências longínquas, produzidas por um acontecer hierárquico, marcado pela primazia das normas. Neste caso, a política tem um peso maior que a técnica, tendo-se em mente que o espaço é um misto de técnicas e políticas. O uso turístico do território segue esta mesma determinação, fato que se pôde constatar ao aferirmos que, entre os agentes de produção espacial em Jericoacoara, o Estado (planejadores e promotores territoriais) tem tido maior peso com relação ao mercado e a sociedade (turistas e população local), devido basicamente ao 
papel efetivo do poder público na produção do espaço para o turismo no nordeste brasileiro, tomando o turismo como um dos principais instrumentos para o desenvolvimento econômico desta região.

A vila de Jericoacoara, recorte espacial ao nível local para o estudo do tema em questão, reproduz as determinações da totalidade e, por ser parte de uma totalidade em movimento, reflete ainda a dinamicidade do mundo. Partindo-se desta premissa, buscamos apreender particularidades do processo de consumo e produção do espaço do turismo através da noção de totalidade em movimento (refazendo-se a todo momento), abrangendo dimensões econômicas, sociais e políticas, em diferentes níveis escalares, muitas vezes, interdependentes e, ao mesmo tempo, embutidas de contradições e conflitos.

Uma análise dos eventos também torna-se reveladora dos processos econômicos, políticos e sociais responsáveis pela produção do espaço, considerando que o evento é também uma fração da totalidade em movimento que se deposita numa fração da totalidade cristalizada. Visto pela idéia de totalidade, os eventos são superpostos e se sucedem (criam continuidade).

No caso de Jericoacoara, alguns eventos destacam-se na produção do espaço local, como a criação da Área de Proteção Ambiental de Jericoacoara (em 1984, época a partir da qual se deu o início de um turismo mais intenso) e a publicação de um artigo do jornal The Washington Post listando Jericoacoara entre as dez praias mais bonitas do mundo (em 1987, fato este que culminou na divulgação internacional e nacional de Jericoacoara enquanto destino turístico). Na década seguinte tem-se o Projeto de Requalificação Urbana da Vila de Jericoacoara (em 1999, quando efetivamente foram criadas as condições infra-estruturais urbanas no local) e a criação, em 2002, do Parque Nacional de Jericoacoara ao redor da vila, como alternativa à contenção do avanço da área urbana.

Como os lugares já possuem um conjunto próprio de existências cristalizadas, há muitas vezes, nas localidades, resistências aos eventos que surgem a partir de uma racionalidade hegemônica, determinando assim uma união horizontal nos lugares. Em Jericoacoara não foi diferente, devido à 
intensa participação do Conselho Comunitário, juntamente com boa parte dos habitantes de Jericoacoara, na produção do espaço local, atuando basicamente como uma forma de contra-racionalidade às determinações hegemônicas.

Mesmo sendo uma APA, desde 1984, e atualmente cercada por um Parque Nacional, a vila de Jericoacoara não está imune a impactos socioambientais de todo tipo, uma vez que diversos agentes sociais continuam intervindo no território com o intuito de criar as condições necessárias para o desenvolvimento do turismo. Como Unidade de Conservação, o Parque Nacional de Jericoacoara necessita de instrumentos (como exemplo, um plano de manejo, ainda inexistente mas em vias de elaboração) que orientem a ocupação racional do espaço físico reservado às moradias, ao lazer e a seu suprimento ${ }^{76}$.

A prática social do turismo acaba por (re)criar o urbano em locais inicialmente escolhidos por não o serem e, no que diz respeito ao Estado do Ceará, este está sendo cada vez mais reconfigurado para inserir-se no contexto de um mercado global, com a implantação de infra-estruturas que respondam a demandas específicas deste mercado, sobretudo demandas turísticas. Com isso, e em função da atividade turística, intensificou-se o processo de urbanização e a circulação na vila de Jericoacoara, transformando uma área originalmente rica em termos de meio ambiente natural (uma bela praia ocupada por um pacato vilarejo de pescadores) à destino turístico internacional. É nestas condições que o turismo torna "bens naturais" em "novas raridades", atribuindo ao espaço um valor de troca.

A materialização (espacialização) das ações do Estado obedece a uma racionalidade hegemônica (inserindo-se fundamentalmente nos interesses privados) e se traduz, também, na produção e no consumo do espaço. Produção e consumo estão intrinsecamente relacionados, pois o espaço é produzido para, num outro momento, ser consumido, bem como o consumo do espaço é também, e ao mesmo tempo, parte integrante do processo de sua

\footnotetext{
${ }^{76}$ Jornal Diário do Nordeste. Opinião. Fortaleza, , 12 de fevereiro de 2004, p.2.
} 
produção, marcada pela vitória do valor de troca sobre o seu valor de uso, limitando o uso do espaço-mercadoria às formas de apropriação privada.

$O$ ato de produzir é, também, $O$ ato de consumir (há uma relação dialética entre produção e consumo do espaço). É desta forma, portanto, que o espaço local de Jericoacoara, assim como tantos outros lugares do país e do mundo, vem sendo produzido ao longo dos últimos anos: uma produção no sentido da urbanização para o turismo, com o efetivo papel do poder público no aprofundamento do uso turístico do território, através da criação de normas que, muitas vezes, traduzem-se na imposição de verticalidades, reduzindo 0 espaço (ou o território usado) à condição de mercadoria.

$\mathrm{Na}$ história do presente, a dinamicidade e a rapidez ganham peso e, ao mesmo tempo em que o capital circula livremente, ele é seletivo do ponto de vista espacial. Como reflexo das determinações impostas pela lógica da especulação e conservação da lucratividade (marcas do modo de produção capitalista), o turismo também possui caráter seletivo, e Jericoacoara apresenta-se como mais um entre os lugares escolhidos. 


\section{REFERÊNCIAS BIBLIOGRÁFICAS}

ABRAMO, P. Pesquisa em ciências sociais, In: HIRANO, S. (Org.). Pesquisa social: projeto e planejamento. São Paulo: T. A. Queiroz, 1979. p. 21-88.

ANDRADE, José V. de. Turismo: fundamentos e dimensões. 8.ed. São Paulo: Ática, 2002.

ANDRADE, Manuel C. de. Territorialidades, desterritorialidades, novas territorialidades: os limites do poder nacional e do poder local. In.: SANTOS, M. ; SOUZA, M. A. de ; SILVEIRA, M. L. Território: globalização e fragmentação. 5.ed. São Paulo: HUCITEC, 2002, p. 213-220.

AUGÉ, Marc. Não-lugares: introdução a uma antropologia da supermodernidade. 4.ed. Campinas, SP: Papirus, 2004.

AULICINO, Madalena Pedroso. Algumas implicações da exploração turística dos recursos naturais. In.: RODRIGUES, Adyr B. Turismo e ambiente: reflexões e propostas. São Paulo: HUCUTEC, 1997, p. 27-36.

BARRIOS, Sonia. A produção do espaço. In.: SOUZA, Maria Adélia A. de; Santos. A construção do espaço. São Paulo: Nobel, 1986, p.1-24.

BAUDRILLARD, Jean. A sociedade de consumo. Rio de Janeiro : Elfos Ed.; Lisboa : Edições 70, 1995. (Coleção Ciência \& Sociedade; 3).

BECKER, Bertha. Polítias e planejamento do turismo no Brasil. In.: YÁZIGI, Eduardo; CARLOS, Ana Fani A. e Cruz (orgs.) Turismo: espaço, paisagem e cultura. São Paulo: HUCITEC, 1996, p. 181-192.

BENEVIDES, Ireleno Porto. Práticas e territorialidades turísticas e planejamento governamental do turismo no Ceará. Tese de Doutorado. São Paulo: FFLCH/USP, 2004.

BENKO, Georges. Organização econômica do território: algumas reflexões sobre a evolução no século XX. In.: SANTOS, M. ; SOUZA, M. A. de ; 
SILVEIRA, M. L. Território: globalização e fragmentação. 5.ed. São Paulo: HUCITEC, 2002, p. 51-71.

BERTONCELLO, Rodolfo. Las prácticas turísticas y sus implicâncias sócio espaciales. In.: CORIOLANO, Luzia Neide M. T. (org.) Turismo com ética. Fortaleza: UECE, 1998, p. 57-75.

BOULLÓN, Roberto C. Planejamento do espaço turístico. Bauru, SP: EDUSC, 2002 (Coleção Turis).

BOYER, Marc. Historia do turismo de massa. Bauru, SP : EDUSC, 2003 (Coleção Turis).

BRASIL. Ministério do Meio Ambiente. IBAMA. Instrução normativa nำ, de janeiro e 2001. Instrução normativa $n^{\circ}$ 4, de 15 de maio de 1992.

BRUNO, Louise. Rio de Janeiro, une metrópole fragmentée: le rôle des favelas et des condomínios fechados dans le processus d'éclatement de la ville et de la societé. In.: DIAS, Leila C. et RAUD, Cécile. Villes et Régions au Brésil. Paris : L'Harmattan.

CARA, Roberto Bustos. El turismo y los procesos de transformación territorial. In: RODRIGUES, Adyr A. B. (Org.) Turismo e geografia: reflexões teóricas e enfoques regionais. São Paulo: HUCITEC, 1996. p. 77-93.

CARLOS, Ana Fani A. O consumo do espaço. In.: CARLOS, Ana Fani A. (org.) Novos caminhos da geografia. São Paulo: Contexto, 1999, p. 173-186. . O lugar no/do mundo. São Paulo: HUCITEC, 1996. A mundialidade do espaço. In.: MARTINS, José de Souza (org.) Henri Lefebvre e o retorno à dialética. São Paulo : HUCITEC, 1996, p. 71-86. 
A natureza do espaço fragmentado. In.: SANTOS, M. ; SOUZA, M. A. de ; SILVEIRA, M. L. Território: globalização e fragmentação. 5.ed. São Paulo: HUCITEC, 2002, p. 191-197.

"Novas" contradições do espaço. In.: CARLOS, Ana Fani A.; DAMIANI, Amélia L.; SEABRA, Odette C. de Lima. O espaço no fim de século: uma nova raridade. 2.ed. São Paulo: Contexto, 2001, p. 62-74.

A (re)produção do espaço urbano. São Paulo: Edusp, 1994.

O turismo e a produção do não lugar. In: YAZIGI, E.; CARLOS, Ana Fani A. ; Cruz, Rita de C. A. da (Orgs.) Turismo: espaço, paisagem e cultura. São Paulo: Hucitec, 1996. p. 25-54.

CHESNAIS, François. A mundialização do capital. São Paulo : Xamã, 1996.

CICOUREL, Aaron. Teoria e método em pesquisa de campo. In: GUIMARÃES, A. Z. Desvendando máscaras sociais. 2. ed. Rio de Janeiro: Livraria Francisco Alves Ed., 1980. p. 87-121.

COMISSÃO DE CONTRA-PROPOSTA DO PROJETO DO PLANO DIRETOR DE DESENVOLVIMENTO URBANO DE JERICOACOARA. Síntese dos trabalhos. Jericoacoara, outubro de 2000.

CONSELHO COMUNITÁRIO DE JERICOACOARA. Dossiê Jeri. Jericoacoara, [2003].

CORIOLANO, Luzia Neide M. T. Turismo e degradação ambiental no litoral do Ceará. In.: LEMOS, Amália I. G. de. Turismo: impactos socioambientais. 2. ed. São Paulo: HUCITEC, 1999.

. Do local ao global: o turismo litorâneo cearense. Campinas, SP: Papirus, 1998 (Coleção Turismo).

CORRÊA, Roberto L. Trajetórias geográficas. 3.ed. Rio de Janeiro: Bertrand Brasil, 2005. 
CRUZ, Rita de C. A. da. Introdução à geografia do turismo. 2.ed. São Paulo: Roca, 2003.

As paisagens artificiais criadas pelo turismo. In: YÁZIGI, E. (Org.). Turismo e paisagem. São Paulo: Contexto, 2002. p. 107-119.

- Políticas de turismo e construção do espaço turísticolitorâneo no nordeste do Brasil. In.: LEMOS, Amália Inês G. de (org.) Turismo: impactos socioambientais. São Paulo: HUCITEC, 1996, p. 263272.

Políticas de turismo e território. São Paulo: Contexto, 2000.

DAMIANI, Amélia L. As contradições do espaço: da lógica (formal) à lógica (dialética), a propósito o espaço. In.: CARLOS, Ana Fani A.; DAMIANI, Amélia L.; SEABRA, Odette C. de Lima. O espaço no fim de século: uma nova raridade. 2.ed. São Paulo: Contexto, 2001, p. 48-61.

Turismo e lazer em espaços urbanos. In.: RODRIGUES, Adyr A. Balastreri (org). Turismo, modernidade, globalização. São Paulo: Hucitec, 1997, p. 46-54.

DEBORD, Guy. A sociedade do espetáculo. 6. reimpr. Rio de Janeiro : Contraponto, 2005.

DIEGUES, Antonio Carlos Santana. As áreas naturais protegidas, o turismo e as populações tradicionais. In.: SERRANO, Célia M. T. ; BRUHNS, Heloisa T. (orgs.) Viagens à natureza: turismo, cultura e ambiente. 6.ed. Campinas, SP: Papirus, 1997, p. 85-102 (Coleção Turismo).

O mito moderno da natureza intocada. 3.ed. São Paulo : HUCITEC, 2001.

DUARTE, Cláudio R. Notas de pesquisa: das contradições do espaço ao espaço vivido em Henri Lefebvre. In.: CARLOS, Ana Fani A.; DAMIANI, Amélia L.; SEABRA, Odette C. de Lima. O espaço no fim de século: uma nova raridade. 2.ed. São Paulo: Contexto, 2001, p. 75-80. 
FIGHERA, Delfina T. Estado e território: suas relações e a globalização. In.: SANTOS, M. ; SOUZA, M. A. de ; SILVEIRA, M. L. Território: globalização e fragmentação. 5.ed. São Paulo: HUCITEC, 2002, p. 108-115.

FONTELES, José O. Turismo e impactos socioambientais. São Paulo: Aleph, 2004.

FONTELES, José O. e SILVA, Antonio José C. da (orgs.) Parque Nacional de Jericoacoara: planejamento participativo 2004-2006. Fortaleza : Ibama, 2006.

GALVÃO, Alessandro G. Jericoacoara sonhada. São Paulo : Annablume, 1995. (Selo universidade ; 27).

GEIGER, Pedro P. Des-territorialização e espacialização. In.: SANTOS, M. ; SOUZA, M. A. de ; SILVEIRA, M. L. Território: globalização e fragmentação. 5.ed. São Paulo: HUCITEC, 2002, p. 233-246.

GOMES, Horieste. A produção do espaço geográfico no capitalismo. São Paulo: Contexto, 1990 (Col. Repensando a Geografia).

GOTTDIENER, Mark. A produção social do espaço urbano. São Paulo : Edusp, 1993.

GOVERNO DO ESTADO. Ceará. Secretaria do Turismo. Demanda turística de Jericoacoara. Fortaleza, fevereiro e 2005.

- Estudos turísticos da SETUR: evolução do turismo no Ceará n.17. 2.e. Fortaleza : SETUR, 2006. . Programa de Ação para o Desenvolvimento do Turismo PRODETUR/CE. Fortaleza: SETUR, 2002. Programa de Desenvolvimento do Turismo no Ceará PRODETUR II. Fortaleza: SETUR, [2004]. 
GOVERNO DO ESTADO. Ceará. Secretaria do Planejamento e Coordenação (SEPLAN) e Instituto de Pesquisa e Estratégia Econômica do Ceará (IPECE). Perfil Básico Municipal - Jijoca de Jericoacoara. Fortaleza, 2005.

GRANGER, Gilles-Gaston. A ciência e as ciências. São Paulo: Editora UNESP, 1994.

HAESBAERT, Rogério. O mito da desterritorialização : do "fim dos territórios" à multiterritorialidade. Rio de Janeiro : Bertrand Brasil, 2004.

HALL, Colin Michael. Planejamento turístico: políticas, processos e relacionamentos. 2.ed. São Paulo: Contexto, 2004.

HARVEY, David. Condição pós-moderna: uma pesquisa sobre as origens a mudança cultural. 13.ed. São Paulo: Loyola, 2004.

HESSEN, Joannes. Teoria do conhecimento. 2. ed. São Paulo : Martins Fontes, 2003.

HIERNAUX NICOLÁS, Daniel. Elementos para un análisis sociogeográfico del turismo. In.: RODRIGUES, Adyr A. B. (org). Turismo e geografia: reflexões teóricas e enfoques regionais. São Paulo : HUCITEC, 1996. p. 39-54.

- Tempo, espaço e apropriação social do território: rumo à fragmentação na mundialização? In.: SANTOS, M. ; SOUZA, M. A. de ; SILVEIRA, M. L. Território: globalização e fragmentação. 5.ed. São Paulo: HUCITEC, 2002, p. 85-101.

IGNARRA, Luiz R. Fundamentos do turismo. São Paulo: Pioneira, 2001.

JAPIASSU, Hilton Ferreira. Introdução ao pensamento epistemológico. 3.ed. revista e ampliada. São Paulo : Livraria Francisco Alves Editora S.A., 1979.

KNAFOU, Remy. L'invention du lieu touristique: la passation d'un contrat et le surgissement simultané d'un nouveau territoire. In.: Revue de Géographie Alpine. n.4, 1991. 
. Turismo e território : por uma abordagem científica do turismo. In.: RODRIGUES, Adyr A. B. (Org.) Turismo e geografia: reflexões teóricas e enfoques regionais. São Paulo : HUCITEC, 1996. p. 62-74.

. Une approche géographique du turisme. In.: L'Espace Géographique, t.26, n.3, 1997, p. 193-204.

KRIPPENDORF, Jost. Sociologia do turismo: para uma nova compreensão do lazer e das viagens. 3.ed. rev. São Paulo : Aleph, 2003 (Série Turismo).

LAZZAROTTI, Olivier. La géographie dans la controverse touristique. In.: Annales de Géographie. n. 580, 1994, p. 627-650.

LEFEBVRE, Henri. O espaço e o Estado (trad. José Augusto Martins Pessoa). In.: La production de l'espace. Paris: Anthropos, 1974.

LEMOS, Amália Ines G. de. Turismo, modernidade e globalização: São Paulo, metrópole mundial. In.: RODRIGUES, Adyr A. B. (Org.) Turismo e geografia: reflexões teóricas e enfoques regionais. São Paulo : HUCITEC, 1996. p. 238-246.

LEVY, Jacques. Entre sociedade civil e sociedade política. In.: SANTOS, M. ; SOUZA, M. A. de ; SILVEIRA, M. L. Território: globalização e fragmentação. 5.ed. São Paulo: HUCITEC, 2002, p. 221-232.

LIMA, Adriana Villarinho de. Sistema de proteção / fiscalização do Parque Nacional de Jericoacoara/CE. S.L., PNUD/IBAMA/DIREC, 2003.

LIMA, Luiz Cruz e SILVA, Ângela M. F. da. O local globalizado pelo turismo: Jeri e Canoa no final do século XX. Fortaleza: EDUECE, 2004.

LIMA, Maria do Céu de. Comunidades pesqueiras marítimas no Ceará: território, costumes e conflitos. Tese de Doutorado. São Paulo: FFLCH/USP, 2002.

LIPIETZ, Alain. O capital e seu espaço. São Paulo: Nobel, 1987. 
LUCHIARI, Maria Tereza D. P. Turismo, natureza e cultura caiçara: um novo colonialismo? In.: SERRANO, Célia M. T. ; BRUHNS, Heloisa T. (orgs.) Viagens à natureza: turismo, cultura e ambiente. 6.ed. Campinas, SP: Papirus, 1997, p. 59-84 (Coleção Turismo).

- Urbanização turística: um novo nexo entre o lugar e o mundo. In.: LIMA, Luiz C. Da cidade ao campo: a diversidade do saberfazer turístico. v.2. Fortaleza, EDUECE, 1998, p. 15-29.

MARTINS, Espedito C. O turismo como alternativa de desenvolvimento sustentável: o caso de Jericoacoara no Ceará. 2002. Tese (Doutorado) Escola Superior de Agricultura "Luiz de Queiroz", Piracicaba, 2002.

MARTINS, Sérgio. Crítica à economia política o espaço. In.: CARLOS, Ana Fani A.; DAMIANI, Amélia L.; SEABRA, Odette C. de Lima. O espaço no fim de século: uma nova raridade. 2.ed. São Paulo: Contexto, 2001, p. 1341.

MARX, Karl. Manuscritos económico-filosóficos. São Paulo: Boitempo, 2004.

MATHIESON, A.; WALL, G. Tourism: economic, physical and social impacts. Repr. New York : Longman Scientific \& Technical, 1990.

MATIAS, Lígia Queiroz ; SILVA, Edson Vicente. A vegetação da APA de Jericoacoara, Ceará - Brasil e suas implicações para o manejo e conservação ambiental. Brasília : Edições IBAMA, 2001 (Série Meio Ambiente em debates ; 41).

MEIRELES, Antonio Jeovah de Andrade. Parecer técnico - Diagnóstico e medidas de planejamento e gestão para o controle do processo acelerado de soterramento de equipamentos públicos pelos sedimentos transportados pelo vento - vila de Jericoacoara. Fortaleza, fevereiro de 2005.

MENDONÇA, Rita. Turismo ou meio ambiente: uma falsa oposição? In.: LEMOS, Amália Inês G. de. Turismo: impactos socioambientais. São Paulo: HUCITEC, 1996. 
MOLINA, Fábio Silveira. Turismo na natureza: um estudo de caso no município de Brotas/SP. Trabalho de Graduação Individual. São Paulo: FFLCH/USP, 2001.

O turismo e seu papel na produção do espaço: reflexões teórico-metodológicas. In.: ENCONTRO NACIONAL DA ANPEGE, 6., 28 a 30 de setembro de 2005. Anais... Fortaleza, 2005.

Turismo e produção do espaço: o caso de Jericoacoara, CE. In.: TALLER INTERNACIONAL DESLOCAMENTOS, CONTACTOS, LUGARES: LA EXPERIÊNCIA DE LA MOVILIDAD Y LA CONSTRUCCIÓN DE OTRAS GEOGRAFÍAS, 11 a 13 de maio de 2005. Annales... Buenos Aires, 2005.

MORAES, Antonio C. R. Geografia: pequena história crítica. 14.ed. São Paulo: HUCITEC, 1995.

NASCIMENTO, Cláudia R. T. do. SA009-A qualidade dos meios de hospedagem em Jericoacoara. In.: Anais do I Encontro de Pós-Graduação e Pesquisa. 2001, p.376-379.

OLIVEIRA, Carlos R. de. Produzindo o espaço do ócio. In.: CARLOS, Ana Fani A.; DAMIANI, Amélia L.; SEABRA, Odette C. de Lima. O espaço no fim de século: uma nova raridade. 2.ed. São Paulo: Contexto, 2001, p. 190-198.

OSEKI, Jorge Hajime. O único e o homogêneo na produção do espaço. In.: MARTINS, José de Souza (org.) Henri Lefebvre e o retorno à dialética. São Paulo : HUCITEC, 1996, p. 109-119.

PIRES, Paulo dos Santos. A dimensão conceitual o ecoturismo. In.: Turismo: visão e ação. Itajaí, SC: UNIVALI, 1(1): 75-91, jan/jul 1998.

O que é ecoturismo? Em busca de uma proposta pela via da abordagem conceitual. In.: Turismo: visão e ação. Itajaí, SC: UNIVALI, 3(6): 119-128, abr/set 2000. 
PLANO DE DESENVOLVIMENTO INTEGRADO DO TURISMO SUSTENTÁVEL DO PÓLO COSTA DO SOL - PDITS. [s.I], Ruschmann Consultores, setembro de 2003.

PREFEITURA MUNICIPAL DE JIJOCA DE JERICOACOARA. Lei n.106 de 01 e dezembro de 2000. Aprova o Plano Diretor de Desenvolvimento Urbano de Jijoca de Jericoacoara e dá outras providências.

RAFFESTIN, Claude. Por uma geografia do poder. São Paulo : Ática, 1993.

RODRIGUES, Adyr A. B. Desafios para os estudiosos do turismo. In: RODRIGUES, Adyr A. B. (Org.) Turismo e geografia: reflexões teóricas e enfoques regionais. São Paulo : HUCITEC, 1996a. p. 17-32.

Geografia e turismo: notas introdutórias. Revista do Departamento de Geografia. São Paulo, n.6, p. 71-82, 1992.

. Turismo e Espaço: rumo a um conhecimento transdisciplinar. 3. ed. São Paulo: Hucitec, 2001.

- Uma abordagem geográfica do espaço do turismo. In: CORIOLANO, Luzia N. M. T. (Org.) Turismo com ética. Fortaleza: UECE, 1998. p. 76-99.

RODRIGUES, Arlete Moysés. A produção e o consumo do espaço para o turismo e a problemática ambiental. In: YAZIGI, E.; CARLOS, Ana Fani A.; Cruz, Rita de C. A. da (Orgs.) Turismo: espaço, paisagem e cultura. São Paulo: Hucitec, 1996. p. 55-62.

SÁNCHEZ, Joan-Eugení. Espacio, economia y sociedad. Madrid : Siglo Veintiuno Editores, 1991.

SANTANA, Paola Verri de. A mercadoria verde: a natureza. In.: DAMIANI, A. L.; CARLOS, Ana Fani A.; SEABRA, O. C. L. O espaço no fim de século : a nova raridade. 2. ed. São Paulo: Contexto, 2001. p. 177-189.

SANTOS, Milton. Economia espacial: críticas e alternativas. 2.ed. São Paulo : Edusp, 2003 (Col. Milton Santos; 3). 
Espaço e Método. 4.ed. São Paulo: Nobel, 1997 (Coleção

Espaços).

- Metamorfoses do espaço habitado. 4.ed. São Paulo:

Hucitec, 1996.

- A natureza do espaço: técnica e tempo, razão e emoção.

São Paulo : EDUSP, 2002a (Col. Milton Santos; 1).

. Pensando o espaço do homem. 5.ed. São Paulo: Edusp,

2004a.

- Por uma outra globalização: do pensamento único à consciência universal. 3.ed. Rio de Janeiro: Record, 2000.

. O retorno do território. In.: SANTOS, M. ; SOUZA, M. A. de

; SILVEIRA, M. L. Território: globalização e fragmentação. 5.ed. São Paulo: HUCITEC, 2002b, p. 15-20.

- Técnica, espaço, tempo: globalização e meio técnicocientífico-informacional. São Paulo : HUCITEC, 1994.

SANTOS, Milton e SILVEIRA, Maria Laura. De uma geografia metafórica da pós-modernidade a uma geografia da globalização. In.: Cultura Vozes. Ano 91, 4(91), jul./ago. 1997, p. 14-30.

- O Brasil: território e sociedade no início o século XXI. 6.ed.

Rio de Janeiro: Record, 2004b.

SANTOS, Theotonio dos. A globalização reforça as particularidades. In.: SANTOS, M. ; SOUZA, M. A. de ; SILVEIRA, M. L. Território: globalização e fragmentação. 5.ed. São Paulo: HUCITEC, 2002, p. 72-76.

SEABRA, Odette Carvalho de L. A insurreição do uso. In.: MARTINS, José de Souza (org.) Henri Lefebvre e o retorno à dialética. São Paulo : HUCITEC, 1996, p. 71-86. 
A muralha que cerca o mar: uma modalidade de uso do solo urbano. Dissertação de mestrado. São Paulo : FFLCH/USP, 1979.

. O pensamento de Henri Lefebvre e a geografia. Boletim Paulista de Geografia, São Paulo, n. 74, p. 7-21, 1994.

. Pensando o processo de valorização e a geografia. Boletim Paulista de Geografia, São Paulo, n. 66, p. 97-104, 1988.

SERRANO, Célia Maria Toledo. Uma introdução à discussão sobre turismo, cultura e meio ambiente. In.: SERRANO, Célia M. T. ; BRUHNS, Heloisa T. (orgs.) Viagens à natureza: turismo, cultura e ambiente. 6.ed. Campinas, SP: Papirus, 1997, p. 11-25 (Coleção Turismo).

SILVEIRA, Maria Laura. Da fetichização dos lugares à produção local do turismo. In.: RODRIGUES, Adyr A. Balastreri (org). Turismo, modernidade, globalização. São Paulo: Hucitec, 1997, p. 36-45.

. Globalização, trabalho, cidades médias. In.: Geo UERJ Revista do Departamento de Geografia. Rio de Janeiro: UERJ, Departamento de Geografia, n. 11, 2002a, p. 11-17.

. Por um conteúdo da reflexão epistemológica da geografia.

In.: SOUZA, A. J.; SOUZA, E. B. C.; MAGNOMI JÚNIOR, L. Paisagem, território, região: em busca da identidade. Cascavel : EDUNIOESTE, 2000, p. 21-28.

Por una epistemología geográfica. In: Bertoncello y CARLOS, Ana Fani A. (comp.) Procesos territoriales en Argentina y Brasil. Buenos Aires: Instituto de Geografia, Facultad de Filosofia y Letras, Universidad de Buenos Aires, 2003, p. 13-26.

. Um país, uma região: fim de século e modernidades na Argentina. São Paulo: FAPESP; LABOPLAN-USP, 1999a.

. Uma globalização desnecessária, um território instável. In.: Ciência Geográfica. Bauru, VIII, v.1 (21), jan./abril, 2002b, p. 43-46. 
Uma situação geográfica: do método à metodologia. In.: Revista Território. Ano IV, no 6, jan.jun. 1999b, p. 21-28.

SMITH, Neil. Desenvolvimento desigual: natureza, capital e a produção do espaço. Rio de Janeiro: Ed. Bertrand Brasil, 1988.

SOJA, Edward. W. Geografias pós-modernas: a reafirmação do espaço na teoria social crítica. Rio de Janeiro: Jorge Zahar Ed., 1993.

SORRE, Max. A noção de gênero de vida e sua evolução. In.: MEGALE, Januário (org). Max Sorre. São Paulo: Ática, 1994, p. 99-123.

SOUZA, Maria Adélia A. de. Geografias da desigualdade: globalização e fragmentação. In.: SANTOS, M. ; SOUZA, M. A. de ; SILVEIRA, M. L. Território: globalização e fragmentação. 5.ed. São Paulo: HUCITEC, 2002, p. 21-28.

TRINDADE JÚNIOR, Saint-Clair C. da. Sujeitos políticos e territorialidades urbanas. In.: CARLOS, Ana Fani A.; DAMIANI, Amélia L.; SEABRA, Odette C. de Lima. O espaço no fim de século: uma nova raridade. 2.ed. São Paulo: Contexto, 2001, p. 150-159.

TULIK, Olga. Turismo e repercussões no espaço geográfico. Turismo em análise, São Paulo, v. 1, n. 1, p. 63-67, nov. 1990.

UNIVERSIDADE ESTADUAL DO CEARÁ - UECE. Núcleo de Gestão e Administração - NUGA. Área de Proteção Ambiental - Jericoacoara. Fortaleza: UECE/NUGA, 1985.

VALLAUX, Camille. El suelo y el Estado. Madrid: Daniel Jorro Editor, 1914.

YÁZIGI, Eduardo. A natureza como identidade espacial o turismo. In.: CORRÊA, R. L. e ROSENDAHL, Z. Religião, identidade e território. Rio de Janeiro: Ed. UERJ, 2001.

. Turismo : uma esperança condicional. 2. ed. São Paulo:

Global, 1999. 
ANEXOS 


\author{
ANEXO 1 \\ PRESIDÊNCIA DA REPÚBLICA \\ CASA CIVIL \\ Subchefia para Assuntos Jurídicos
}

\title{
DECRETO № 90.379, DE 29 DE OUTUBRO DE 1984.
}

Dispõe sobre a implantação de área de proteção ambiental no Município de Acaraú, no Estado do Ceará, e dá outras providências.

O PRESIDENTE DA REPÚBLICA, no uso das atribuições que the confere 0 artigo 81, item III, da Constituição Federal, e tendo em vista o que dispõem o artigo 8º da Lei no 6.902, de 27 de abril de 1981, e o artigo 32, do Decreto no 88.351 , de 1 de junho de 1983 ,

\section{DECRETA:}

Art. 1ํ - Sob a denominação de APA JERICOACOARA, fica declarada área de proteção ambiental, a região situada no Município de Acaraú, no Estado do Ceará, com a delimitação geográfica constante do artigo $3^{\circ}$, deste Decreto.

Art. $2^{\circ}$ - A declaração de possibilitar às comunidades caiçaras 0 exercício de suas atividades, dentro dos padrões culturais estabelecidos historicamente, tem por objetivo proteger e preservar:

a) - os ecossistemas de praias, mangues e restingas;

b) - dunas;

c) - formações geológicas de grande potencial paisagístico e científico;

d) - espécies vegetais e animais principalmente quelônios marinhos;

e) - aves de rapina e praieiras.

Art. $3^{\circ}-$ A APA JERICOACOARA tem a seguinte delimitação geográfica: Partindo do Ponto P-00 de coordenadas geográficas latitude 2050'15" sul e longitude $40^{\circ} 34^{\prime} 00$ " oeste, situado na foz do Riacho do Balseiro, na Barra do Guriu, segue à montante pela margem esquerda do referido Riacho até a confluência com a Lagoa do Carapeba onde está localizado o P-01 de coordenadas geográficas latitude 200'20" sul e longitude $40^{\circ} 32^{\prime} 50^{\prime \prime}$ oeste; deste ponto segue com $76^{\circ}$ rumo SE a distância aproximada de $3450 \mathrm{~m}$ até 0 Alto da Testa Branca onde está localizado o P-02 de coordenadas geográficas latitude $2^{\circ} 50^{\prime} 45^{\prime \prime}$ sul e longitude $40^{\circ} 31^{\prime} 10^{\prime \prime}$ oeste; deste ponto segue com $85^{\circ}$ rumo SE a distância aproximada de $2100 \mathrm{~m}$ até a ponta sul da Lagoa Grande onde está localizado o ponto P-03 de coordenadas geográficas latitude 
$2^{\circ} 50^{\prime} 50^{\prime \prime}$ sul e longitude 4029'50" oeste; deste ponto segue com 78을 rumo NE a distância aproximada de $4950 \mathrm{~m}$ até o ponto P-04 de coordenadas geográficas latitude $2^{\circ} 50^{\prime} 20^{\prime \prime}$ sul e longitude $40^{\circ} 27^{\prime} 15^{\prime \prime}$ oeste localizado ao norte da Lagoa da Gijoca; deste ponto segue com 79ำ rumo NE a distância aproximada de $4300 \mathrm{~m}$ até o ponto P-05 de coordenadas geográficas latitude $2^{\circ} 49^{\prime} 55^{\prime \prime}$ sul e longitude 4025'00" oeste; deste ponto segue com 29ํㅜ rumo NO a distância aproximada de $2700 \mathrm{~m}$ até a Praia do Desterro onde está localizado o ponto P-06 de coordenadas geográficas latitude $2^{\circ} 48^{\prime} 40^{\prime \prime}$ sul e longitude 40 -25'45" oeste; deste ponto segue rumo oeste pela linha costeira contornando o continente a distância aproximada de $21 \mathrm{Km}$ até encontrar o ponto P-00 marco inicial desta descrição.

Art. $4^{\circ}$ - $\mathrm{Na}$ implantação e funcionamento da APA JERICOACOARA, serão adotadas as seguintes medidas prioritárias:

I - zoneamento a ser efetivado através de portaria da Secretaria Especial do Meio Ambiente - SEMA, do Ministério do Interior, em estreita articulação com a Prefeitura Municipal de Acaraú, as Universidades do Estado do Ceará, o Órgão Estadual de Meio Ambiente e a Sociedade Cearense de Cultura e MeioAmbiente - SOCEMA, indicando-se as atividades a serem incentivadas, em cada zona, bem como as que deverão ser restringidas ou proibidas, de acordo com a legislação aplicável;

II - utilização dos instrumentos legais e dos incentivos financeiros governamentais, para assegurar a proteção de Zona de Vida Silvestre, o uso racional do solo, e a aplicação de outras medidas referentes à salvaguarda dos recursos ambientais, sempre que consideradas necessárias;

III - aplicação, quando cabíveis, de medidas legais, destinadas a impedir ou evitar o exercício de atividades causadoras de sensível degradação da qualidade ambiental;

IV - divulgação das medidas previstas neste Decreto, objetivando o esclarecimento da comunidade local sobre a APA e suas finalidades; biótico.

$V$ - aquisição, pela SEMA, de áreas que tiverem especial interesse

Art. 5 - Na APA JERICOACOARA ficam proibidas ou restringidas:

I - a implantação ou ampliação de atividades industriais potencialmente poluidoras, capazes de afetar mananciais de água;

II - a realização de obras de terraplenagem e a abertura de canais, quando essas iniciativas importarem em sensível alteração das condições ecológicas locais, principalmente na Zona de Vida Silvestre, onde a biota será protegida com maior rigor;

III - o exercício de atividades capazes de provocar acelerada erosão das terras ou acentuado assoreamento das coleções hídricas; 
IV - o exercício de atividades que ameacem extinguir as espécies raras da biota regional;

$\mathrm{V}$ - o uso de biocidas, quando indiscriminado, ou em desacordo com as normas ou recomendações técnicas oficiais.

Art. 60 - A abertura de vias de comunicações, de canais, e a implantação de projetos de urbanização, dependerão de autorização prévia da Secretaria Especial do Meio Ambiente - SEMA, do Ministério do Interior, que somente poderá concedê-la:

a) - após estudo do projeto, exame das alternativas possíveis e avaliação de suas consequências ambientais;

b) - mediante a indicação das restrições e medidas consideradas necessárias à salvaguarda dos ecossistemas atingidos.

Parágrafo único - A autorização concedida pela Secretaria Especial do Meio Ambiente - SEMA, do Ministério do Interior, não implicará na dispensa de outras autorizações ou licenças, federais, estaduais ou municipais, porventura exigíveis.

Art. $7^{0}$ - Para melhor controlar seus efluentes e reduzir o potencial poluidor das construções destinadas ao uso humano, não serão permitidas:

a) - a construção de edificações, em terrenos que, por suas características, não comportarem a existência simultânea de poços para receber o despejo de fossas sépticas, e de poços de abastecimento d'água, que fiquem a salvo de contaminação, quando não houver rede de coleta e estação de tratamento de esgoto, em funcionamento;

b) - o despejo, no mar e em outros corpos receptores, de esgotos e outros efluentes, sem tratamento adequado que impeça a contaminação das águas.

Art. 8ำ - Visando manter o padrão cultural e paisagístico da região, não serão permitidas construções que descaracterizem os componentes arquitetônicos locais ou que prejudiquem a paisagem regional típica.

Art. 9o - Nos terrenos de marinha, e acrescidos, conforme conceituados nos artigos $2^{\circ}$ e $3^{\circ}$, do Decreto-lei ํㅜ 9.760 , de 5 de setembro de 1946, não será permitida a retirada de areia, ou de material rochoso, nem admitidas construções de qualquer natureza com exceção de embarcadouros.

Art. 10 - Com vistas a impedir a pesca predatória, nas águas marítimas ou interiores da APA e nas suas proximidades, será dada especial atenção ao cumprimento da legislação pertinente, e das normas expedidas pela Superintendência do Desenvolvimento da Pesca - SUDEPE, do Ministério da Agricultura. 
Art. 11 - Em casos de epidemias e endemias, veiculadas por animais silvestres, o Ministério da Saúde e a Secretaria de Saúde, do Estado do Ceará, poderão, em articulação com a Secretaria Especial do Meio Ambiente - SEMA, do Ministério do Interior, promover programas especiais, para controle dos referidos vetores.

Art. 12 - Ficam estabelecidas, na APA JERICOACOARA, Zonas de Vida Silvestre, destinadas, prioritariamente, à salvaguarda da biota, e cuja delimitação será explicitada no respectivo zoneamento.

$\S 1^{0}$ - A delimitação de que trata este artigo deverá abranger:

a) - as formações de dunas;

b) - as áreas cobertas pela areia;

c) - os lagos e lagoas permanentes e/ou periódicos;

d) - os manguezais;

e) - a formação geológica denominada "Serrote".

$\S 2^{\circ}$ - As Zonas de Vida Silvestre compreenderão, também, as áreas mencionadas no artigo 18, da Lei oㅡ 6.938, de 31 de agosto de 1981, as quais, quando forem de domínio privado serão consideradas como Áreas de Relevante Interesse Ecológico (ARIE), e ficarão sujeitas às restrições de uso e penalidades estabelecidas, nos termos dos Decretos 88.351, de 1 de junho de 1983, e 89.532, de 6 de abril de 1984.

Art. 13 - Visando à proteção da biota, nas Zonas de Vida Silvestre, não será permitida a construção de edificações, exceto as destinadas à realização de pesquisa e ao controle ambiental.

Art. 14 - Nas Zonas de Vida Silvestre não será permitida atividade degradadora ou potencialmente causadora de degradação ambiental, inclusive o porte de armas de fogo e de artefatos ou instrumentos de destruição da biota, ressalvados os casos objeto de prévia autorização, expedida, em caráter excepcional pela Secretaria Especial do Meio Ambiente - SEMA, do Ministério do Interior.

Art. 15 - Para os efeitos do art. 18, da Lei oㅜ 6.938, de 31 de agosto de 1981, consideram-se como de preservação permanente as nascentes ou "olhos d'água" e o seu entorno, num raio de 60 metros, exceto a faixa necessária para assegurar a utilização e o bom escoamento das águas.

Art. 16 - A APA JERICOACOARA será supervisionada, administrada e fiscalizada pela Secretaria Especial do Meio Ambiente - SEMA, do Ministério do Interior, em articulação com a Prefeitura Municipal de Acaraú, o Órgão Estadual do Meio Ambiente, a Superintendência do Desenvolvimento da Pesca - SUDEPE e a Capitania dos Portos de Fortaleza - CE.

Art. 17 - Com vistas a atingir os objetivos previstos para a APA JERICOACOARA, bem como a definir as atribuições e competências no 
controle de atividades potencialmente degradadoras, a Secretaria Especial do Meio Ambiente - SEMA, do Ministério do Interior, poderá, ainda, firmar convênios com órgãos e entidades públicas ou privadas.

Art. 18 - As penalidades previstas nas Leis nos 6.902, de 27 de abril de 1981, e 6.938, de 31 de agosto de 1981, serão aplicadas, pela Secretaria Especial do Meio Ambiente - SEMA, do Ministério do Interior, aos transgressores das disposições deste Decreto, com vistas ao cumprimento das medidas preventivas e corretivas, necessárias à preservação da qualidade ambiental.

Parágrafo único - Dos atos e decisões da SEMA, referentes à APA JERICOACOARA, caberá recurso ao Conselho Nacional do Meio Ambiente CONAMA.

Art. 19 - Os investimentos e a concessão de financiamentos e incentivos, da Administração Pública Federal, direta ou indireta, destinados à APA JERICOACOARA, serão previamente compatibilizados com as diretrizes estabelecidas neste Decreto.

Art. 20 - A Secretaria Especial do Meio Ambiente - SEMA, do Ministério do Interior, poderá designar, através de portaria, Grupo de Assessoramento Técnico para implementação das atividades de administração, zoneamento e fiscalização da APA.

Art. 21 - A Secretaria Especial do Meio Ambiente - SEMA, do Ministério do Interior, expedirá as instruções normativas necessárias ao cumprimento deste Decreto.

Art. 22 - Este Decreto entrará em vigor na data de sua publicação, revogadas as disposições em contrário. República.

Brasília, 29 de outubro de 1984; $163^{\circ}$ da Independência e $96^{\circ}$ da

JOÃO FIGUEIREDO

Mário David Andreazza 


\section{ANEXO 2 \\ PRESIDÊNCIA DA REPÚBLICA CASA CIVIL \\ Subchefia para Assuntos Jurídicos}

\section{DECRETO DE 4 DE FEVEREIRO DE 2002.}

Cria o Parque Nacional de Jericoacoara, redefine os limites da Área de Proteção Ambiental de Jericoacoara, no Estado do Ceará, e dá outras providências.

O PRESIDENTE DA REPÚBLICA, no uso da atribuição que the confere o art. 84, inciso IV, da Constituição, e tendo em vista o disposto nos arts. 11, 15 e 22 da Lei no 9.985, de 18 de julho de 2000,

\section{DECRETA:}

Art. 10 - Fica transformada parte da Área de Proteção Ambiental de Jericoacoara, criada pelo, Decreto no 90.379, de 29 de outubro de 1984, para compor o Parque Nacional de Jericoacoara, nos municípios de Cruz, Jijoca e Jericoacoara, no Estado do Ceará, com área de oito mil, quatrocentos e dezesseis hectares e oito ares.

Art. $2^{\circ}$ - Os objetivos do Parque Nacional de Jericoacoara são os de proteger e preservar amostras dos ecossistemas costeiros, assegurar a preservação de seus recursos naturais e proporcionar oportunidades controladas para uso público, educação e pesquisa científica.

Art. 3o - O Parque Nacional de Jericoacoara apresenta seus limites descritos a partir das cartas topográficas militares em escala 1:100.000 Ml: 556 e 557, editadas pela Diretoria do Serviço Geográfico do Exército. O poligonal fica definido a partir do seguinte memorial descritivo: inicia-se no Ponto P-00, de coordenadas geográficas aproximadas latitude 2050'15" sul e longitude 4034'00" oeste, situado na foz do Riacho do Balseiro, na Barra do Guriu; segue a montante pela margem esquerda do referido Riacho até a confluência com a Lagoa do Carapeba, onde está localizado o P-01, de coordenadas geográficas latitude ${ }^{2}{ }^{\circ} 50^{\prime} 20 "$ sul e longitude 4032'50" oeste; deste ponto, segue com $76^{\circ}$ rumo SE a distância aproximada de $3.450 \mathrm{~m}$ até o Alto da Testa Branca, onde está localizado o P-02, de coordenadas geográficas latitude 2050'45" sul e longitude 40ำ31'10" oeste; deste ponto, segue com 85을 rumo SE a distância aproximada de $2.100 \mathrm{~m}$ até a ponta sul da Lagoa Grande, onde está localizado o ponto P-03, de coordenadas geográficas latitude 2050'50" sul e longitude 4029'50" oeste; deste ponto, segue com 78으 rumo NE a distância aproximada de $4.950 \mathrm{~m}$ até o ponto P-04, de coordenadas geográficas latitude 2050'20" sul e longitude 4027'15" oeste, localizado ao norte da Lagoa da 
Gijoca; deste ponto, segue com 79ำ rumo NE a distância aproximada de 4.300 $\mathrm{m}$ até $\mathrm{o}$ ponto P-05, de coordenadas geográficas latitude 2049'55" sul e longitude $40^{\circ} 25^{\prime} 00^{\prime \prime}$ oeste; deste ponto, segue com $29^{\circ}$ rumo NO a distância aproximada de $2.700 \mathrm{~m}$ até a Praia do Desterro, onde está localizado o ponto P-06, de coordenadas geográficas latitude $2^{\circ} 48^{\prime} 40^{\prime \prime}$ sul e longitude $40^{\circ} 25^{\prime} 45^{\prime \prime}$ oeste; deste ponto, segue rumo oeste pela linha costeira a distância aproximada de vinte e um quilômetros, contornando o continente, até encontrar o ponto P-00, marco inicial desta descrição.

Art. 4ํ - Fica incorporada à área do Parque Nacional de Jericoacoara a faixa costeira de um quilômetro de largura, paralela à linha costeira, a partir do ponto P-06, com uma distância aproximada de vinte e um quilômetros até 0 ponto P-00, destinada à zona de proteção costeira.

Art. 5으 - Os limites da Área de Proteção Ambiental de Jericoacoara ficam redefinidos pelo seguinte memorial descritivo: inicia-se no ponto de coordenadas geográficas aproximadas de latitude $02^{\circ} 47^{\prime} 30^{\prime \prime}$ sul e longitude $40^{\circ} 31^{\prime} 11$ " oeste, $\mathrm{V}-1$; deste ponto, segue para o ponto de latitude $02^{\circ} 47^{\prime} 29^{\prime \prime}$ sul e longitude $40^{\circ} 31^{\prime} 04^{\prime \prime}$ oeste, V-2; segue para o ponto de latitude $02^{\circ} 47^{\prime} 30^{\prime \prime}$ sul e longitude $40^{\circ} 30^{\prime} 53^{\prime \prime}$, oeste, V-3; daí, parte com azimute $180^{\circ} 29^{\prime} 35^{\prime \prime}$ e distância 190,59 m até o vértice V-4; deste, com azimute $149^{\circ} 19^{\prime} 58^{\prime \prime}$ e distância 389,55 m chega-se ao vértice $V-5$; deste, com azimute $134^{\circ} 48^{\prime} 31^{\prime \prime} \mathrm{e}$ distância 124,85 m chega-se ao vértice V-6; deste, com azimute $122^{\circ} 03^{\prime} 37^{\prime \prime e}$ distância 188,11 m chega-se ao vértice V-7; deste, com azimute 144 ${ }^{\circ} 14^{\prime} 30^{\prime \prime} \mathrm{e}$ distância 107,83 m chega-se ao vértice V-8; deste, com azimute 121 ${ }^{\circ} 13^{\prime} 34^{\prime \prime}$ e distância 91,41 m chega-se ao vértice $V$-9; deste, com azimute $152^{\circ} 39^{\prime} 24^{\prime \prime}$ e distância 80,99 m chega-se ao vértice $\mathrm{V}$-10; deste, com azimute 131 ${ }^{\circ} 16^{\prime} 53^{\prime \prime}$ e distância 71,19 m chega-se ao vértice $V-11$; deste, com azimute $89^{\circ} 49^{\prime 2} 20^{\prime \prime}$ e distância $225,71 \mathrm{~m}$ chega-se ao vértice $\mathrm{V}-12$; deste, com azimute $90^{\circ} 00^{\prime} 00^{\prime \prime} \mathrm{e}$

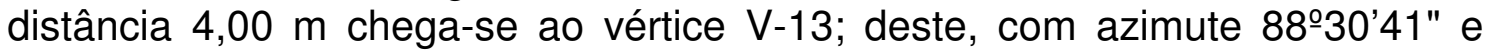
distância 92,38 m chega-se ao vértice $V$-14; deste, com azimute $77^{\circ} 33^{\prime} 48^{\prime \prime}$ e distância $57,35 \mathrm{~m}$ chega-se ao vértice $\mathrm{V}-15$; deste, com azimute $81^{\circ} 17^{\prime} 41^{\prime \prime} \mathrm{e}$ distância 45,92 m chega-se ao vértice $\mathrm{V}$-16; deste, com azimute $78^{\circ} 37^{\prime} 23^{\prime \prime} \mathrm{e}$ distância 157,66 m chega-se ao vértice V-17; deste, com azimute $77^{\circ} 23^{\prime} 56^{\prime \prime}$ e distância 150,39 m chega-se ao vértice V-18; deste, com azimute $349^{\circ} 27^{\prime} 38^{\prime \prime}$ e distância 100,05 m chega-se ao vértice $V-19$; deste, com azimute $358^{\circ} 01^{\prime} 08^{\prime \prime}$ e distância $22,85 \mathrm{~m}$ chega-se ao vértice $\mathrm{V}$ - 20 ; deste, com azimute $348^{\circ} 28^{\prime} 47^{\prime \prime} \mathrm{e}$ distância 113,31 m chega-se ao vértice V-21; deste, com azimute $348^{\circ} 20^{\prime} 16^{\prime \prime}$ e distâ ncia 55,51 m chega-se ao vértice V-22; deste, com azimute $348^{\circ} 20^{\prime} 15^{\prime \prime}$ e distância 131,29 m chega-se ao vértice V-23; deste, com azimute $299^{\circ} 55^{\prime} 31^{\prime \prime} \mathrm{e}$ distância 163,43 m chega-se ao vértice V-24; deste, com azimute 299²5'37" e distância $689,04 \mathrm{~m}$ chega-se ao vértice $\mathrm{V}-25$, retornando ao ponto $\mathrm{V}-1$, início deste perímetro, perfazendo uma área de duzentos e sete hectares.

Art. 60 - O Parque Nacional de Jericoacoara será administrado pelo Instituto Brasileiro do Meio Ambiente e dos Recursos Naturais Renováveis, que adotará as medidas necessárias à sua efetiva implantação.

Art. $7^{0}$ - Este Decreto entra em vigor na data de sua publicação. 
Art. $8^{\circ}$ - Fica revogado o art. $3^{\circ}$ do Decreto № 90.379 , de 29 de outubro de 1984.

Brasília, 4 de fevereiro de 2002; 1810 da Independência e 1140 da República.

FERNANDO HENRIQUE CARDOSO

José Carlos Carvalho 


\section{ANEXO 3 \\ SERVIÇO PÚBLICO FEDERAL MINISTÉRIO DO MEIO AMBIENTE INSTITUTO BRASILEIRO DO MEIO AMBIENTE E DOS RECURSOS NATURAIS RENOVÁVEIS - IBAMA}

\section{INSTRUÇÃO NORMATIVA № 4 - DE 15 DE MAIO DE 1992}

A Presidência do Instituto Brasileiro do Meio Ambiente e dos Recursos Naturais Renováveis - IBAMA, no uso das suas atribuições que lhe conferem a Lei ํㅜ 7.735 de 22 de fevereiro de 1989 bem como o artigo 83, inciso XIV do Regimento Interno aprovado pela Portaria MINTER $n-445$, de 16 de agosto de 1989, e o artigo 24 e seus incisos do Anexo I ao Decreto no 78 de 5 de abril de 1991, e considerando o artigo 9o e suas alíneas, da Lei no 6.902, de 27 de abril de 1981, a Resolução CONAMA no 10 de 14 de dezembro de 1988, o Decreto no 90.379, de 29 de outubro de 1984, e o artigo $1^{\circ}$, incisos I e II e os artigos 29 e 30 do Decreto no 99.274 de 6 de junho de 1990, resolve:

1. Expedir a presente Instrução Normativa - IN, que redefine normas para o gerenciamento da Área de Proteção Ambiental - APA de Jericoacoara, visando compatibilizar a preservação da área com o desenvolvimento, possibilitando às comunidades nativas o exercício de suas atividades dentro dos padrões culturais historicamente estabelecidos.

2. Nos termos desta Instrução Normativa e para os fins previstos no Decreto n. 90.379, de 29 de outubro de 1984, fica a APA de Jericoacoara dividida em 8 (oito) Sistemas de Terra, configurados na planta de escala 1:100.000 contida no Documento de denominado Relatório Final - Diretrizes Gerais de Uso da APA de Jericoacoara - CE, - SEMA/1987, e nas plantas de escalas 1:25.000 e 1:2.000 (vila).

3. A aplicação das normas de que trata esta Instrução Normativa dar-seá sem prejuízo das disposições previstas em leis, regulamentos e demais legislações complementares que visam à defesa do meio ambiente.

4. A Licença Prévia - LP para o exercício de atividade na APA de Jericoacoara, conforme previsto no artigo 19 do Decreto n. 99.274, de 6 de junho de 1990, somente será concedida pelo órgão ambiental competente e seus prepostos, observadas as normas contidas nesta Instrução Normativa.

5. O acompanhamento das atividades desenvolvidas na APA de Jericoacoara, bem como o controle e a fiscalização das disposições, contidas nesta Instrução Normativa serão exercidas pelo IBAMA que, para esse fim, se articulará, mediante convênios, com a Prefeitura Municipal, órgãos do Governo do Ceará, Governo Federal e entidades de natureza civil. 
6. Para efeito dessa Instrução Normativa adotar-se-ão as seguintes definições:

A - Zona de Vida Silvestre - É a área onde a proteção é essencial, tanto para a sobrevivência das espécies da fauna e flora da biota regional consideradas vulneráveis, endêmicas ou ameaçadas de extinção quanto para os biotipos raros de significado regional, nacional ou mundial; $1,24 \mathrm{~km}^{2}$;

B - Sistema de Terra I - Serrote (serra pequena) com área total de

C - Sistema de Terra II - Base do Serrote (sopé do morro) com área total de $1,12 \mathrm{~km}^{2}$;

D - Sistema de Terra III - Dunas (montes de areia formados pelo vento) com área total de $34,15 \mathrm{~km}^{2}$;

E - Sistema de Terra IV - Praias com área total de $1,52 \mathrm{~km}^{2}$;

F - Sistema de Terra V - Lagoas com área total de 15,44 km² ;

G - Sistema de Terra VI - Mangues (Vegetação da desembocadura do rio no mar) com área total de $0,32 \mathrm{~km}^{2}$;

H - Sistema de Terra VII - Tabuleiro (Planalto arenoso com vegetação arbustiva e arbórea) com área total de $0,60 \mathrm{~km}^{2}$;

I - Sistema de Terra VIII - Vila (povoado de Jericoacoara) com área total de $0,41 \mathrm{~km}^{2}$ que fica delimitado de acordo com a seguinte descrição perimétrica:

a) Ponto de Amarração: Farol de Jericoacoara, cujas coordenadas geográficas são 02ํ4'15,72" Sul e 4029'58,02" Oeste;

b) Vetor de Amarração: 1.523,42 metros, a partir do Ponto de Amarração, no rumo verdadeiro 238 $28^{\prime} \mathrm{Az}$ até o Cruzeiro (defronte ao Cemitério), denominado $\mathrm{Pa}$ e a partir deste, os seguintes comprimentos e rumos verdadeiros relacionados a seguir;

c) Limite Sul - Do ponto Pa segue numa distância de 91,95m e com azimute de $160^{\circ} 28^{\prime} 00^{\prime \prime}$ até o ponto $\mathrm{Pb}$, desse ponto segue numa distância de $215,66 \mathrm{~m}$ e com azimute de 196051'00" até o ponto Pc, desse ponto segue numa distância de 339,97m e com azimute de 258 24 '00" até o ponto Pd, desse ponto segue numa distância de $321,24 \mathrm{~m}$ e com azimute de 286으' até o ponto $\mathrm{Pe}$, desse ponto segue numa distância de 159,60m e azimute de 322은 50 " até o ponto $\mathrm{Pf}$, desse ponto segue numa distância de $126,20 \mathrm{~m}$ e azimute de $330^{\circ} 55^{\prime} 10^{\prime \prime}$ passando pelo ponto $\mathrm{Pg}$ até o ponto $\mathrm{Ph}$, desse ponto

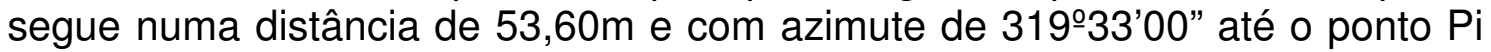
desse ponto segue numa distância de $67,00 \mathrm{~m}$ e com azimute de $323^{\circ} 20^{\prime} 20^{\prime \prime}$ até o ponto $\mathrm{Pj}$; 
d) Limite Norte - Do ponto Pa segue numa distância de 79,92m e com azimute de 30900'00" até o ponto $\mathrm{Pb}$, desse ponto segue numa distância de $167,99 \mathrm{~m}$ e com azimute de $304^{\circ} 00^{\prime} 00^{\prime \prime}$ até o ponto Pc, desse ponto segue numa distância de $173,93 \mathrm{~m}$ e com azimute de 3030'00" até o ponto $\mathrm{Pd}$, desse ponto segue numa distância de $83,57 \mathrm{~m}$ e com azimute de $310^{\circ} 00^{\prime} 00^{\prime \prime}$ até o ponto $\mathrm{Pe}$, desse ponto segue numa distância de $487,28 \mathrm{~m}$ e azimute de 261ำ16'40" até o ponto Pf até $\mathrm{Pg}$, desse ponto segue numa distância de $80,64 \mathrm{~m}$ e azimute de $257^{\circ} 51^{\prime} 50^{\prime \prime}$ até o ponto $\mathrm{Ph}$, desse ponto segue numa distância de 48,60m e com azimute de 16157'30" até o ponto Pi, desse ponto segue numa distância de 80,00m e com azimute de 1561'10" até o ponto Pj, desse ponto segue numa distância de 27,40m e com azimute de 126⒈14'45" até o ponto Pj (este limite corresponde a extrema porção ocidental da casa do Arteiro), término desta descrição, totalizando uma área de 41,42 ha e um perímetro de 2.604,53m;

7. Das atividades a serem permitidas ou incentivadas, restringidas ou proibidas, na APA de Jericoacoara:

\section{1 - Do Uso Urbano - Rural}

7.1.1 - Ficam proibidas novas ocupações e assentamentos rurais ou urbanos, em toda a APA de Jericoacoara, exceto no Sistema de Terra VIII, sendo que qualquer loteamento ou edificação deverá ser submetido à apreciação do IBAMA, ouvida a Prefeitura de Cruz.

7.1.2 - Toda e qualquer atividade a ser desenvolvida na APA de Jericoacoara depende do licenciamento do IBAMA.

7.1.3 - Ficam proibidas descargas de lixo ou aterro em todos os Sistemas de terra, sem prévia consulta à Prefeitura de Cruz, ouvido o IBAMA.

7.1.4 - Ficam proibida, em toda a APA, a instalação de indústrias potencialmente poluidoras.

7.1.5 - Fica proibido o uso de motos, bugues, e de quaisquer outros tipos de veículos automotores, em todos os Sistemas de Terra, exceto nas transversais ao longo das atuais estradas e vias de acesso ao Sistema de Terra VIII. O tráfego de veículos no Sistema de Terra VIII somente será permitido para o transporte de doentes, mercadorias ou de veículos cujos proprietários, comprovadamente, residam no local. O controle do trânsito deverá ser efetuado pela Prefeitura de Cruz com apoio do IBAMA.

7.1.6 - As atividades ligadas à agricultura e à pecuária deverão ser desenvolvidas em áreas cercadas numa faixa de restinga dentro do Sistema de Terra III, definida pelo IBAMA com Zona Agropastoril. O pastoreio extensivo será permitido nos Sistemas de Terra I, II e III, exceto para os suínos. Os módulos rurais terão as dimensões definidas pelo IBAMA, de acordo com as necessidades de uso de cada ocupante. 
7.1.7 - Fica proibida, em qualquer parte dos Sistemas de Terra a prática de "camping", exceto no Sistema de Terra VIII.

7.1.8 - Fica proibida em todos os Sistemas de Terra, qualquer atividade ou prática de recreação que venha causar degradação ao meio ambiente.

7.1.9 - Fica proibido em qualquer local da APA o uso de agrotóxicos e defensivos agrícolas dos tipos organoclorados e mercuriais.

7.1.10 - Fica proibida a compra e venda de imóveis em qualquer Sistema de Terra, sem prévia consulta à Prefeitura de Cruz, e ao IBAMA. Quando se tratar de terreno da Marinha deverá ser consultado, obrigatoriamente, a Secretaria de Patrimônio da União - DSPU - e a Capitania dos Portos de Fortaleza - CE.

7.1.11 - Fica proibida a retirada de qualquer tipo de material ou sedimentos (areia barro, pedras ou conchas marinhas) em todos os Sistemas de Terra, exceto com finalidade de uso local e com prévia autorização do IBAMA.

7.1.12 - Todo e qualquer projeto de implantação de infra-estrutura turística no Sistema de Terra VIII deverá ser precedido de um Estudo de Impacto Ambiental e respectivo RIMA, que enfatizará as questões sócioeconômicas e culturais, a ser submetido à análise do IBAMA exceto aqueles inferiores a $250 \mathrm{~m}^{2}$ (duzentos e cinqüenta metros quadrados) de área construída.

\section{2 - Da Proteção à Comunidade e a Vila}

7.2.1 - Fica estabelecida a fração máxima de $500 \mathrm{~m}^{2}$ (quinhentos metros quadrados) por módulo urbano, com até $50 \%$ (cinqüenta por cento) de área construída para residências, bares e restaurantes. Para hotéis, pousadas e assemelhados será admitida a utilização máxima de 2 (dois) módulos como anteriormente definidos, sendo proibida a construção de piscinas, lagoas artificiais, chafarizes e similares.

7.2.2 - O gabarito máximo de altura das edificações será sempre de 1 (um) pavimento, e a edificação jamais terá altura superior a 4,0m (quatro metros), a partir do nível da soleira (base).

7.2.3 - Somente serão permitidas construções ou edificações que estejam dentro de alinhamento e direcionamento das ruas conforme estabelecido pela Prefeitura de Cruz ouvido o IBAMA.

7.2.4 - As ampliações ou novas construções somente serão permitidas mediante a adoção de medidas para o destino dos esgotos, que não poderão despejar seus dejetos nas ruas, córregos, mar, ou a céu aberto.

7.2.5 - As construções já existentes deverão igualmente atender o disposto no item anterior. 
7.2.6 - Toda e qualquer construção residencial ou comercial deverá ter fossa séptica, não permitida a sua instalação com menos de $50 \mathrm{~m}$ (cinqüenta metros) de distância do poço (cisterna) de abastecimento de água potável.

7.2.7 - Fica limitado o número de pousadas, hotéis e assemelhados ao atualmente existente.

7.2.8 - Os valores culturais da Comunidade de Jericoacoara deverão ser preservados de projetos e estudos de educação ambiental, economia doméstica, extensão rural, apoio ao artesanato e organização comercial, aprovados pelo IBAMA.

7.2.9 - Ficam declaradas Zonas de Vida Silvestre - ZVs: as dunas, as lagoas, os mangues, o serrote, a base do serrote, e as praias especialmente onde haja desova dos quelônios (tartarugas marinhas).

7.2.10 - Para toda e qualquer atividade pesqueira desenvolvida dentro dos limites da APA de Jericoacoara deverá ser observada rigorosamente, a legislação pertinente do IBAMA, especialmente a Lei Federal ํo 7.679, de 23 de novembro de 1988.

\section{3 - Das Disposições Gerais}

7.3.1 - Qualquer mudança de uso ou finalidade edificações somente será efetuada após prévia autorização do IBAMA.

7.3.2 - Os alvarás de funcionamento dos restaurantes, bares, pousadas, etc., localizados na APA de Jericoacoara serão liberados pela Prefeitura Municipal de Cruz ouvido o IBAMA.

7.3.3 - A infra-estrutura e os equipamentos destinados ao atendimento de saúde, sem prejuízos de outras legislações pertinentes, e não poderão funcionar em edificação que esteja em desacordo com esta Instrução Normativa, ou ser acrescidos novos pontos que venham conflitar com estas normas.

7.3.4 - Para bares, restaurantes, casas de saúde e escolas será obrigatório o uso de água corrente.

7.3.5 - Fica determinado que todas as placas das pousadas, restaurantes, bares e hotéis terão que ter o máximo de $1,50 \mathrm{~m}$ (um metro e meio) de comprimento por 1,0m (um metro).

7.3.6 - Fica proibida nos Sistemas de Terra, a afixação de "outdoors", luminosos, anúncios ou qualquer outra forma de comunicação visual em fachadas de prédios, ou muros, que venham comprometer a harmonia arquitetônica da Vila.

7.3.7 - O licenciamento, nos termos do item 4 desta Instrução Normativa, para a instalação de geradores elétricos fica condicionado à 
apresentação de projeto específico, no qual deverá ser adotado o sistema de descarga silenciosa voltada para a terra (abafamento).

7.3.8 - A instalação de rede elétrica na APA de Jericoacoara fica condicionada à apresentação de Relatório de Impacto Ambiental - RIMA a ser submetido à apreciação do IBAMA.

7.3.9 - Fica proibido o corte de árvores em qualquer Sistema de Terra sem a prévia autorização, do IBAMA.

7.3.10 - Fica proibido o corte de vegetação em áreas de Reservatórios Ecológicas, tais como: manguezais, dunas, restingas, margens de cursos d'água, lagoas, e outras consideradas como de preservação permanente, nos termos do artigo $2^{\circ}$, da Lei $\mathrm{n}^{\circ} \mathbf{4 . 7 7 1}$, de 15 de setembro de 1965.

7.3.11 - As atividades de pesquisa científica deverão ser estimuladas pelos órgãos competentes, mediante a prévia apresentação do projeto, e posterior homologação pelo IBAMA.

7.3.12 - O IBAMA deverá articular-se com o Governo Estadual e Municipal bem como com a comunidade nativa e entidades civis, para elaborar e executar o Plano de Gestão da APA que deverá integrar os aspectos de preservação com os de desenvolvimento.

8 - Fica revogada a I.N. №3, de 2 de janeiro de 1989 - Maria Tereza Jorge Pádua, Presidenta do IBAMA - a partir da data da publicação desta I.N.

9 - A presente Instrução Normativa entra em vigor a partir da data de sua publicação no "Diário Oficial" da União. 


\title{
ANEXO 4 \\ SERVIÇO PÚBLICO FEDERAL MINISTÉRIO DO MEIO AMBIENTE \\ INSTITUTO BRASILEIRO DO MEIO AMBIENTE E DOS RECURSOS NATURAIS RENOVÁVEIS - IBAMA
}

\author{
INSTRUÇÃO NORMATIVA № 4 - DE JANEIRO DE 2001
}

\begin{abstract}
O PRESIDENTE DO INSTITUTO BRASILEIRO DO MEIO AMBIENTE E DOS RECURSOS NATURAIS RENOVÁVEIS - IBAMA, no uso das suas atribuições que the conferem a Lei no 7.735 de 22 de fevereiro de 1989; pela Estrutura Regimental anexa ao Decreto 으 3.059, de 14 de maio de 1999 e pelo Regimento Interno aprovado pela Portaria GM/MINTER no 445, de 16 de agosto de 1989; considerando o disposto na Lei o 5.197, de 3 de janeiro de 1967, em especial os artigos 6o e 17; no Decreto no 76.623 , de 17 de novembro de 1975; na Lei o 9.605 de 12 de fevereiro de 1998, em especial o artigo 29; no Decreto no 3.607 de 21 de setembro e 2000; na Lei no 9.985, de 18 de junho de 2000, em especial o contido em seu artigo 15 e o que consta no Processo IBAMA no 02007.000783/01-60 - Representação do Ceará
\end{abstract}

\section{RESOLVE:}

expedir a presente Instrução Normativa que redefine normas para o gerenciamento da Área de Proteção Ambiental (APA) de Jericoacoara/CE, visando compatibilizar a preservação com 0 desenvolvimento da área, propiciando às comunidades nativas exercerem suas atividades de acordo com os padrões culturais historicamente estabelecidos.

Art. $1^{\circ}$ - Nos termos desta Instrução Normativa e para os fins previstos no Decreto n. 90.379, de 29 de outubro de 1984, fica a APA de Jericoacoara dividida em 8 (oito) Sistemas de Terra, onde o Sistema de Terra VIII, que representa a Vila, está configurado em planta na escala 1:2.000 contida no processo IBAMA no 02007.000783/01-60 - Representação do Ceará.

Art. $2^{\circ}$ - A aplicação das normas de que trata esta IN dar-se-á sem prejuízo das disposições previstas em leis, regulamentos e demais legislações complementares que visam à preservação e conservação dos recursos naturais renováveis, da qualidade de vida e do meio ambiente.

Art. 3o - O licenciamento para o exercício de atividade na APA de Jericoacoara, conforme previsto no artigo 19 do Decreto n. 99.274, de 6 de junho de 1990, somente será concedido pelo IBAMA, observadas as normas contidas nesta Instrução Normativa.

Art. 40 - O acompanhamento das atividades desenvolvidas na APA de Jericoacoara, bem como o controle e a fiscalização das disposições, contidas 
nesta Instrução Normativa serão exercidas pelo IBAMA que, para esse fim, se articulará e celebrará convênios com a Prefeitura Municipal, órgãos do Governo do Ceará, Governo Federal e entidades de natureza civil.

Art. 5ำ - Para efeito dessa Instrução Normativa adotar-se-ão as seguintes definições:

I) Zona de Vida Silvestre - É a área onde a proteção é essencial, tanto para a sobrevivência das espécies da fauna e flora da biota regional consideradas vulneráveis, endêmicas ou ameaçadas de extinção, quanto para os biotipos raros de significado regional, nacional ou mundial; $1,24 \mathrm{~km}^{2}$;

II) Sistema de Terra I - Serrote (serra pequena) com área total de III) Sistema de Terra II - Base (sopé) do Serrote com área total de até
$1,00 \mathrm{~km}^{2}$;

IV) Sistema de Terra III - Campo de Dunas (montes de areia depositada pela ação dos ventos) com área total de até $33,90 \mathrm{~km}^{2}$;

V) Sistema de Terra IV - Praias com área total de até $1,52 \mathrm{~km}^{2}$; $15,44 \mathrm{~km}^{2}$;

VI) Sistema de Terra V - Lagoas interdunares com área total de até

VII) Sistema de Terra VI - Manguezais (ecossistemas litorâneos que ocorrem em terrenos baixos sujeitos a ação das marés localizados em área relativamente abrigadas como baías, estuários e lagunas) com área total de até $0,32 \mathrm{~km}^{2}$;

VIII) Sistema de Terra VII - Tabuleiro (forma topográfica de terreno que se assemelha a planaltos, terminando, via de regra, de forma abrupta. Essas paisagens de topografia plana, aparecem, de modo geral, em toda a costa do Nordeste brasileiro) com área total de até $0,60 \mathrm{~km}^{2}$;

IX) Sistema de Terra VIII - Vila (povoado de Jericoacoara) com área total de $0,78 \mathrm{~km}^{2}$, delimitada por uma poligonal, cujo perímetro mede $3.525,33$ $\mathrm{m}$, tendo como confrontantes: ao Norte e a Oeste, o Oceano Atlântico; ao Sul e a Leste, o restante da APA de Jericoacoara. Essa poligonal tem seu perímetro assim descrito:

- Partindo-se do ponto inicial do perímetro, com coordenadas iniciais iguais a: $331.047,47 \mathrm{E}$, e 9.691.304,37 N, tem-se:

Vértice 001; deste, com azimute $80^{\circ} 07^{\prime} 20^{\prime \prime}$ e distância $239,88 \mathrm{~m}$ chega-se ao

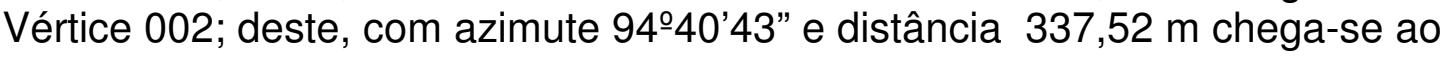
Vértice 003; deste, com azimute 119055'39" e distância 689,85m chega-se ao Vértice 004; deste, com azimute 16941'07" e distância 417,91m chega-se ao Vértice 005 ; deste, com azimute $202^{\circ} 42^{\prime} 18^{\prime \prime}$ e distância 35,21 m chega-se ao Vértice 006; deste, com azimute $253^{\circ} 47^{\prime} 58^{\prime \prime}$ e distância $576,30 \mathrm{~m}$ chega-se ao 
Vértice 007; deste, com azimute 284ㄴㄹ' $35^{\prime \prime}$ e distância $56,12 \mathrm{~m}$ chega-se ao Vértice 008; deste, com azimute 332 $3{ }^{\circ}$ '24" e distância 80,99 m chega-se ao Vértice 009; deste, com azimute 30113'53" e distância 91,42 m chega-se ao Vértice 010; deste, com azimute 324⒈'19" e distância 107,82m chega-se ao Vértice 011 ; deste, com azimute $302^{\circ} 03^{\prime} 46^{\prime \prime}$ e distância $188,11 \mathrm{~m}$ chega-se ao Vértice 012; deste, com azimute 31448'19" e distância 124,85m chega-se ao Vértice 013; deste, com azimute 329ำ19'58" e distância 389,55m chega-se ao Vértice 014; deste, com azimute $\quad 0^{\circ} 29^{\prime} 35$ ” e distância 190,60 m chega-se ao Vértice 001 ; fechando o perímetro.

\title{
CAPÍTULO 1
}

DOS USOS E ATIVIDADES A SEREM PERMITIDOS OU INCENTIVADOS RESTRINGIDOS OU PROIBIDOS NA APA DE JERICOACOARA

\author{
Seção I \\ Dos Usos Urbano e Rural
}

Art. 60 - Ficam proibidas novas ocupações e assentamentos rurais ou urbanos em toda a APA de Jericoacoara, exceto no Sistema de Terra VIII.

Art. $7^{\circ}$ - Ficam proibidas a compra, a venda ou qualquer outro tipo de transação em qualquer Sistema de Terra considerado Zona Silvestre sem a prévia anuência do IBAMA e do IDACE - Instituto do Desenvolvimento Agrário do Ceará. Quando se tratar de terreno da marinha, deverá ser consultada, obrigatoriamente, a Secretaria de Patrimônio da União - DSPU.

Art. $8^{\circ}$ - Toda a atividade que implique o uso de recursos ambientais, ou modificação do meio ambiente na APA de Jericoacoara depende do licenciamento do IBAMA, ouvida a Prefeitura Municipal de Jijoca de Jericoacoara.

Art. 9o - Ficam proibidos em todos os Sistemas de Terra da APA de Jericoacoara:

a) descarga de lixo, ou aterro sanitário; instalação de indústrias potencialmente poluidoras;

b) a prática de "camping", exceto no Sistema de Terra VIII, com autorização prévia do IBAMA, ouvida a Prefeitura Municipal de Jijoca de Jericoacoara.

c) qualquer atividade ou prática de recreação que venha a causar degradação ao meio ambiente;

d) a prática da caça;

e) o uso de agrotóxicos, ou defensivos agrícolas dos tipos organoclorados e mercuriais;

f) a retirada de qualquer tipo de material ou sedimentos (areia, barro, pedras, conchas ou algas marinhas), exceto com finalidade de uso local e com prévia autorização do IBAMA; 
g) o corte de árvores sem prévia autorização do IBAMA, ouvida a Prefeitura Municipal de Jijoca de Jericoacoara;

h) o corte de vegetação em áreas de Reservas Ecológicas, tais como: manguezais, dunas, restingas, margens de rios e lagoas, topo de morros e outras consideradas como de preservação permanente nos termos do art. $2^{\circ}$ da Lei $n^{\circ} 4.771$, de 15 de setembro de 1965. Terra IV.

Art. 10ำ - O uso de barcos a motor só será permitido no Sistema de

Art. $11^{\circ}$ - As atividades ligadas à agricultura e à pecuária intensiva deverão ser desenvolvidas em áreas cercadas, numa faixa de restinga dentro do Sistema de Terra III, a ser definida pelo IBAMA com Zona Agropastoril. O pastoreio extensivo será permitido nos Sistemas de Terra I, II e III, exceto para os suínos. Os módulos rurais terão as dimensões definidas pelo IBAMA, de acordo com as necessidades de uso de cada ocupante.

Art. $12^{\circ}$ - Fica proibida a circulação de motos, buggys e de quaisquer outros tipos de veículos automotores, bem como competições esportivas motorizadas em todos os Sistemas de Terra, exceto nos casos relacionados abaixo e mediante prévio credenciamento pela Prefeitura Municipal de Jijoca de Jericoacoara:

a) se residente na APA de Jericoacoara.

b) na vias de acesso ao Sistema de Terra VIII da APA de Jericoacoara.

c) em roteiros turísticos preestabelecidos e aprovados pelo IBAMA.

Art. 13ำ - A circulação de veículos no Sistema de Terra VIII somente será permitida nas ruas destinadas pelo Plano Diretor de Desenvolvimento Urbano - PDDU a tal fim, e para os casos abaixo relacionados, devendo o controle de trânsito ser efetuado pela Prefeitura de Municipal de Jijoca de Jericoacoara, com apoio do IBAMA:

a) veículo de moradores da Vila, devidamente cadastrados e identificados pelo órgão competente do município;

b) veículos locais de serviços de turismo (responsável pelo translado de turistas no trecho de dunas);

c) veículos de carga e descarga para abastecimento;

d) veículos para limpeza pública;

e) ambulâncias, bombeiros e segurança;

f) veículos do Órgão Gestor da APA.

Art. 14ํㅡ - Será permitido o estacionamento permanente de veículos no interior da Vila somente nas seguintes situações:

a) em edificações que disponham de área de estacionamento interno;

b) em locais predeterminados pela Prefeitura ouvido o IBAMA;

c) durante o embarque e desembarque de passageiros e cargas.

Parágrafo único - Nos demais casos, será utilizado o estacionamento localizado na entrada da Vila. 
Seção II

Da Proteção à Comunidade e à Vila

Art. 15ํ - A Taxa de Ocupação (T.O.) máxima do terreno será de $40 \%$ (quarenta por cento).

Art. 16ำ - A área construída máxima da edificação será de $40 \%$ (quarenta por cento) do terreno.

Art. $17^{\circ}$ - $O$ gabarito máximo de altura das edificações será de $7,5 \mathrm{~m}$ (sete metros e meio) a partir do nível da soleira (base), sendo permitida a construção de segundo piso.

Art. $18^{\circ}$ - Fica proibida a construção de lagoas artificiais, chafarizes e similares, sendo permitida a construção de piscinas, desde que providas de sistema adequado de filtragem e tratamento assim como de poço para abastecimento.

Art. 19 - Somente serão permitidas construções ou edificações que estejam dentro do alinhamento e direcionamento das ruas, conforme estabelecido pelo Plano Diretor de Desenvolvimento Urbano - PDDU, de Jijoca de Jericoacoara.

Art. $20^{\circ}$ - As edificações, ampliações ou reformas serão licenciadas pelo IBAMA. Para tanto se faz obrigatória a apresentação de requerimento, acompanhado de projeto completo da obra a ser realizada, em concordância com esta IN e com o Plano Diretor de Desenvolvimento Urbano - PDDU, do município.

Art. $21^{\circ}$ - Quelquer mudança de uso ou finalidade da edificação somente será permitida após prévia autorização do IBAMA ouvida a Prefeitura de Municipal de Jijoca de Jericoacoara, e desde que observadas as disposições desta IN e do Plano Diretor de Desenvolvimento Urbano - PDDU, do município.

Art. 22ํ- Não será permitido em novas construções ou naquelas já existentes, qualquer sistema de esgotos que despejem seus dejetos nas ruas, em córregos, no mar, em lagoas ou a céu aberto.

Art. 23ํ - Toda e qualquer construção residencial ou comercial, localizada em área não atendida por serviço público de esgotamento sanitário deverá obrigatoriamente, ter fossa séptica instalada a $50 \mathrm{~m}$ (cinqüenta metros) ou mais de distância do poço ou de cacimba para captação de água potável.

Art. 24ำ - Todo estudo e projeto de pesquisa para a APA de Jericoacoara deverá contemplar a preservação dos valores culturais da comunidade resguardando as peculiaridades locais, e ser autorizado e acompanhado do IBAMA.

Art. 25ํ - Todo e qualquer projeto de empreendimento turístico deverá ser precedido de Estudo de Impacto Ambiental - EIA e respectivo Relatório de Impacto Ambiental - RIMA enfatizando as questões ambientais, sócioeconômicas e culturais e serão submetidos à aprovação do IBAMA, exceto se a área a ser construída for inferior a $500 \mathrm{~m}^{2}$ (quinhentos metros quadrados). 
Art. 26ํㅡ - Ficam declaradas Zonas de Vida Silvestre - ZVs: as dunas, as lagoas, os mangues, o serrote, a base do serrote, e as praias, especialmente onde haja desova dos quelônios (tartarugas marinhas).

Art. $27^{\circ}$ - Para toda e qualquer atividade pesqueira desenvolvida dentro dos limites da APA de Jericoacoara deverá ser observada a legislação vigente.

Art. 28ㅇ - Ficam proibidos o abate e a comercialização de qualquer tipo de animal nos logradouros públicos (praças e vias).

Art. 29ำ - Fica proibida a ocupação de logradouros públicos (praças e vias) com barracas destinadas à comercialização de mercadorias, sem a prévia autorização da Prefeitura de Municipal de Jijoca de Jericoacoara, ouvido o IBAMA.

\section{CAPÍTULO II}

Das Disposições Gerais

Art. $30^{\circ}$ - Os alvarás de funcionamento dos bares restaurantes, hotéis, pousadas e similares, e demais estabelecimentos comerciais e de serviços localizados no Sistema de Terra VIII serão expedidos pela Prefeitura de Municipal de Jijoca de Jericoacoara, ouvido o IBAMA.

Art. $31^{\circ}$ - Será obrigatório o uso de água tratada nos equipamentos de saúde, educativos, em bares restaurantes, pousadas, hotéis e similares.

Art. $32^{\circ}$ - As placas de pousadas, restaurantes, bares, hotéis e demais estabelecimentos comerciais e de serviços terão dimensão máxima de $1,50 \mathrm{~m}$ (um metro e cinqüenta centímetros) de comprimento, por 1,0 m (um metro) de largura.

Art. 33ํ - Fica proibida, em todos os Sistemas de Terra, a afixação de "outdoors", luminosos, anúncios ou qualquer outra forma de comunicação visual sem a prévia autorização do IBAMA.

Art. $34^{\circ}-$ O licenciamento, nos termos do item art. $4^{\circ}$ desta IN, para a instalação de geradores elétricos fica condicionado à apresentação de projeto específico, no qual deverá ser adotado o sistema de descarga silenciosa voltada para a terra (abafamento).

Art. $35^{\circ}$ - Qualquer projeto para implantação ou ampliação de rede elétrica, ou de telefonia, na APA de Jericoacoara, deverá ser licenciado pelo IBAMA.

Art. $36^{\circ}$ - As atividades de pesquisa científica na APA de Jericoacoara deverão ser estimuladas pelos órgãos competentes, mediante a prévia apresentação do projeto respectivo e sua homologação por parte do IBAMA.

Art. 37ํㅡ - O IBAMA deverá articular-se com o Governo Estadual e Municipal, com a comunidade local e entidades civis para criação do Conselho Gestor da APA, visando a elaboraação e implementação do Plano de Gestão 
da APA, o qual deverá compatibilizar os aspectos de preservação com os de desenvolvimento.

Art. 38ำ - A presente Instrução Normativa entrará em vigor a partir da data de sua publicação no "Diário Oficial" da União. 1992.

Art. 39ำ - Fica revogada a Instrução Normativa n 4, de 15 de maio de

\author{
HAMILTON NOBRE CASARA \\ PRESIDENTE DO IBAMA
}

